\title{
تعويض ضحايا الاتجار بالبشر \\ بين القواعد التقليدية والوسائل المستحدثة
}

\author{
shel \\ د / حسام الدين محمود حسن \\ مدرس بقسم القانون المدنى \\ كليتتالحقوق ـ جامعت المنصورة
}




\section{هقدمة}

لقــد بـدأ الاهتمـام بجريمـة الاتجـار بالبشر يتزايــ فـى الوقت العـالى بـصورة

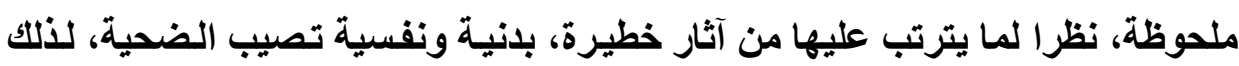

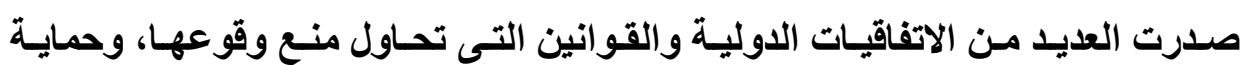
الضحايا، وتقديم الدعم والمساعدة لهم.

فجريمـة الاتجـار بالبشر هـى جريمـة محليـة ودوليـة، والتى غالبـا مـا تـرتبط

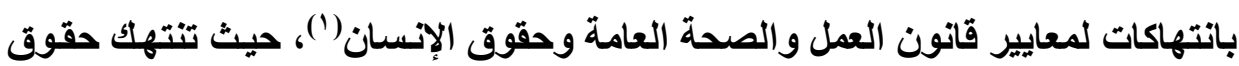
العـال وتخضعهم للعمل الجبرى، فضلا لمـا يترتب عليهـا مـن أضرار بلنيـة ونفسية وإخلال بالصحة العامة، وإهدار لكرامة وحقوق الإنسان.

ويتمثـل جـوهر مفهـوم الاتجــار بالبـشر فـى اسـتغلال الأشـخاص رغمـــــن

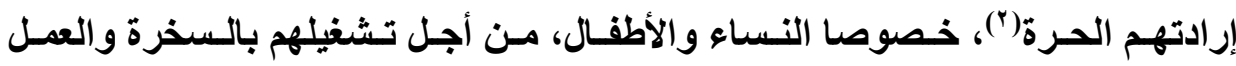
الاستغلالى، بما فيه الاستغلال الجنسى، وهو من أفظع انتهاكات حقوق الإنسان، ويكمن أصلـه فى الظـروف الاجتماعيـة والاقتصادية السائدة فـى البلـدان التهى ينتمى إليهـا (الضحايا(")

(1) Alison Siskin and Liana Sun Wyler, Trafficking in Persons: U.S. Policy and Issues for Congress, Congressional Research Service, 2013, P. 1.

(2) Alline Pedra Jorge-Birol, Empowering Victims of Human Trafficking: the Role of Support, Assistance and Protection Policies, HUMSEC Journal, Issue 2, No date, P. 164.

(3) Jayashri Srikantlah, Perfect victims and real survivors: The iconic victim in domestic human trafficking law, Poston University Law Review, Vol. 87: 157, 2007, P. 162. 
وقد انتشرت فى مصر العديد من صور جرائم الاتجار بالبشر، بمـا فى ذلك،

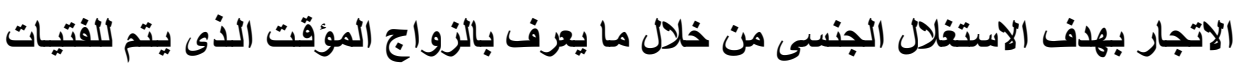

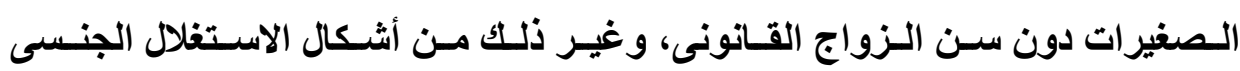

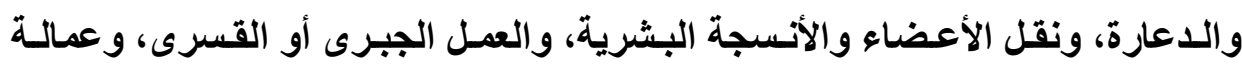

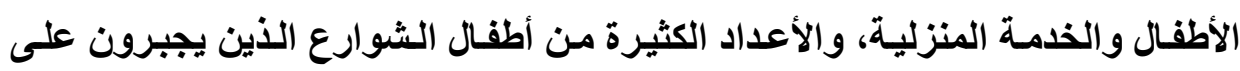
التسول، ويتعرضون للاستغلال فى الدعارة. ويترتب على هذه الجريمة الخطيرة العديد من الآثار السلبية، والأضرار البدنية

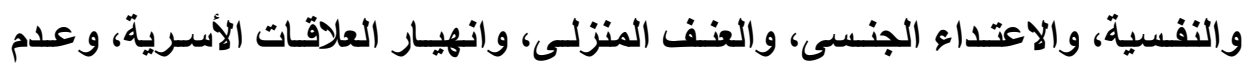

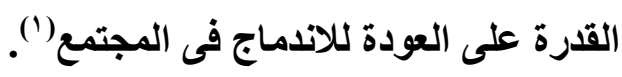
ومما لاثكك فيه، أنه يترتب على ارتكاب أى جريمـة وقوع ضحايا أو متضررين

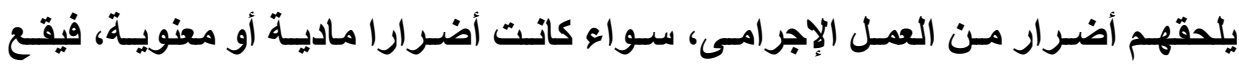

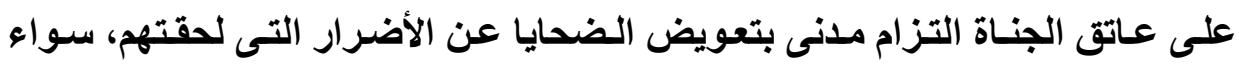

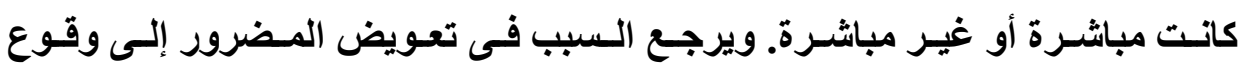

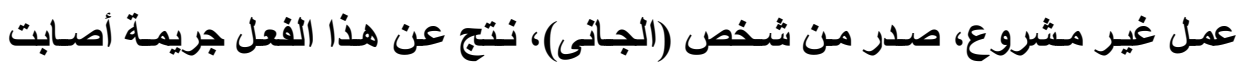

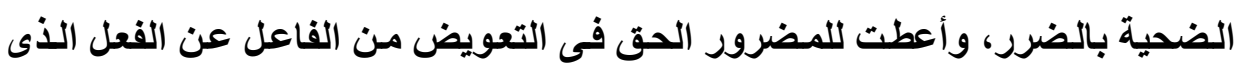

ويقصد بالتعويض: دفع مبلغ مالى للضحية عن الأضرار الجسدية أو النفسية أو

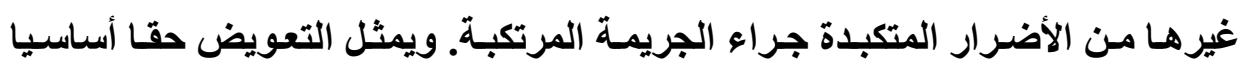
ينبغى أن يعترف به للضحايا فى إطار عملية جبر الأضرار، حيث يوفر لهم المزيد من الهن

(1) Frances Simmons, Making possibilities realities: Compensation for trafficked people, Sydney Law Review, Vol. 34:511, No date, P. 511. 
الثقة فى نظـام العدالة، لمـا يمثله مـن اعتراف بـالأذى الذى لحق بهـم نتيجة ارتكـاب

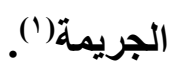

وعـادة مـا يهتم المضرور بالمسئولية المدنيـة أكثر مـن اهتمامسه بمـا عداها

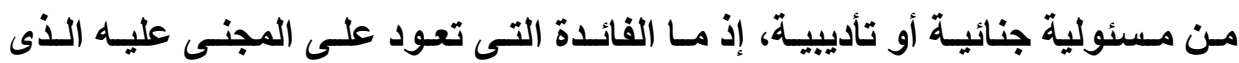

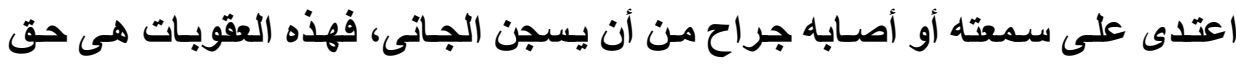
المجتمع، ويبقى بعد ذلك حق المضرور فى تعويض يساعده على جبر مـا لحقه من جراء الجريمة.

ويمثل التعويض جانبا مهمـا من جوانب معالجة انتهاكـات حقوق الإنسان التى يعانى منها الأشخاص المتجر بهم. فللتعويض أهمية كبرى من جوانب عديدة: فعلى المستوى المجتمعى: يمثل منح التعويض اعتر (فا بأن جريمة خطيرة قد ارتكبت فى حق الفرد. وعلى المستوى الفردى: يساهم منح التعويض فى إعادة العدالة وجبر الأضرار والآلام التى لحقت بالمضرور من الجريمـة. وعلى المستوى العلى يمكن أن يساهم

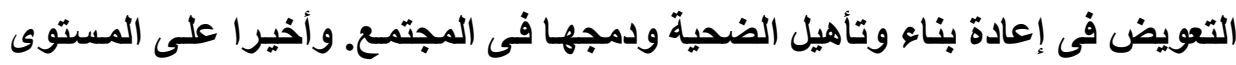
العقابى: يمثل دفع المتاجر بالبشر للتعويض نوع أو شكل من العقاب له وردع لغيره من

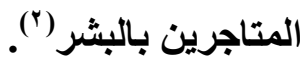

(1) نصر الدين بوسماحة، حقوق ضحايا الجرائم الدولية على ضوء أحكام القانون الدولى، دار الفكر

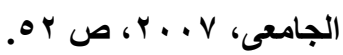

(2) Comp. act, European action for compensation for trafficked persons, Guidance on representing trafficked persons in compensation claims, A practical tool for lawyers, counseling centres and service providers, $P$. 3. 
ومن ثم، وجدنا أنه يجب البحث عما إذا كانت القواعد التقليدية العامة للمسئولية

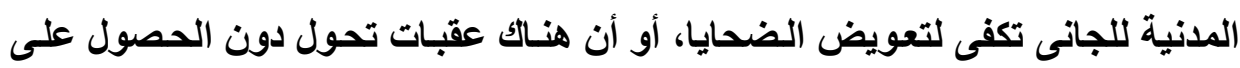
التعويض من خلال هذه القواعد، ثم وجدنا ضرورة البحث عن مدى مسئولية الدولية عن تعويض الضحايا وكيفية الحصول عليه.

وبناء على ما تقام، رأينا تقسيم هذا البحث إلى بابين، على أن نقام لهمـا بفصل تمهيدى عن تعريف جريمة الاتجار بالبشر وعناصرها، وذلك على النحو الآتى: الفصل التمهيدى: مفهوم الاتجار بالبشر. الباب الأول: تعويض ضحايا الاتجار بالبشر وفقا للقواعد التقليدية للمسئولية

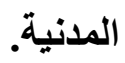
الباب الثانى: تعويض ضحايا الاتجار بالبشر من خلال صندوق الضمان. 


\section{الفصل التمهيدى \\ هفهوم الاتجار بالبشر}

\section{تمهيد وتقتسيم:}

ينبغى علينا قبل البدء فى بحث مسألة تعويض ضحايا جريمة الاتجار بالبشر أن نعرف أولا ما المقصود بهذه الممارسات الخطيرة، وما هى عناصرها، حتى يتسنى لنـا معرفـة مـا يمثلـه هذا السلوك من عمل غير مشروع، يستتبع تعويض الضحايا عن فئن

$$
\text { الأضرار التى تلحقها من جرائها. }
$$

وبناء على ذلك، سنقسم هذا الفصل التمهيدى إلى مبحثين، وذلك على النحو

المبحث الأول: تعريف الاتجار بالبشر.

المبحث الثانى: عناصر الاتجار بالبشر. 


\section{المبحث الأول}

\section{تعريف الاتجار بالبشر}

لقد عرف بروتوكول منع وقمع ومعاقبة الاتجـار بالأشخاص، وبخاصـة النساء والأطفـال، المكمـل لاتفاقيـة الأمـم المتحـدة لمكافــة الجريمـة المنظمـة عبـر الوطنيـة، "الاتجار بالأشخاص" فى المادة ب فقرة (أ) بأنه:"تجنيد أشخاص أو نقلهم أو تثقيلهم أو إيواؤهم أو استقبالهم، بواسطة التهديد بالقوة أو استعمالها، أو غير ذلكك من أشكال

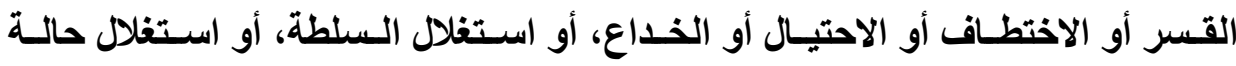

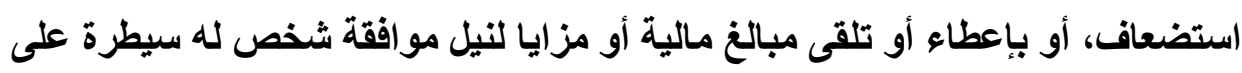
شخص آخر لغرض الاستغلال. ويشمل الاستغلال، كحد أدنى، استغلال دعارة الغير أو

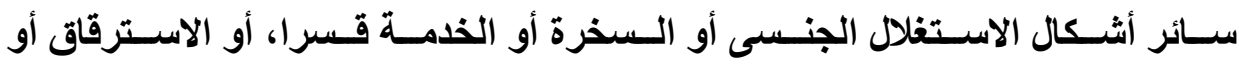
الممارسات الثبيهة بالرق، أو الاستعباد أو نزع الأعضاء".

وفى الفقرة (ج) من نفس المادة، يعتبر تجنيد طقل أو نقله أو تنقيلـه أو إيواؤه أو استقباله لغرض الاستغلال اتجارا بالأشخاص، حتى إذا لم ينظو على استعمال أى من

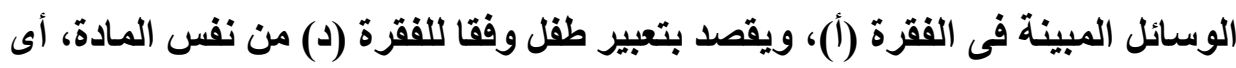
شخص دون الثامنة عشرة من العمر (').

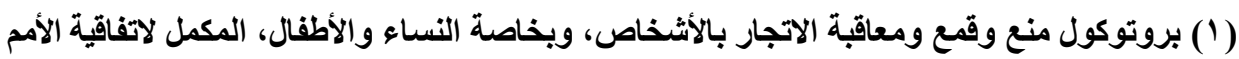

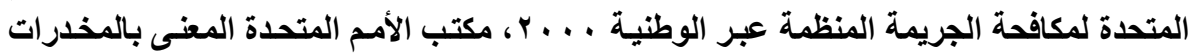
والجريمة، ؛ . . r، متاح على الموقع الإكترونى:

http://www.protectionproject.org/wp-content/uploads/2010/09/UN-

Convention-against-Organized-Crime-and-Protocols-Ar.pdf, 1/12/2014.

$$
\text { OVA مجلت البحوث القانونيتوالإقتصاديت }
$$


لقد عرف الاتجار بالبشر القانون المصرى رقم \& ؟ لسنة ـ ـ ـ ب بشأن مكافحة

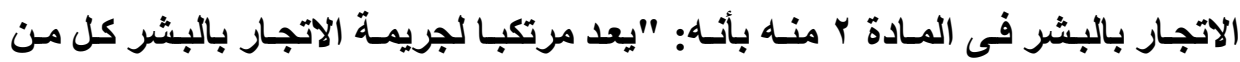

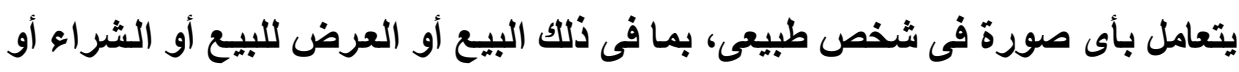

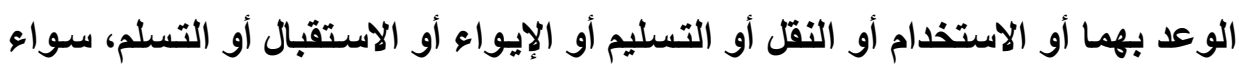

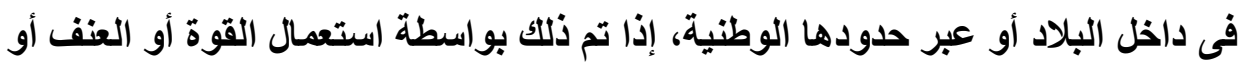

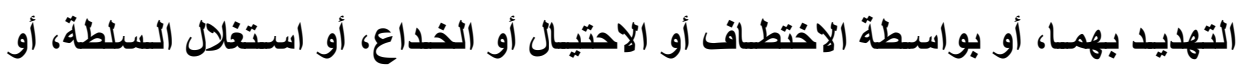
استغلال حالة الضعف أو الحاجة، أو الوعد بإعطاء أو تلقى مبالغ مالية أو مزايا مقابل الحصول على موافقة شخص على الاتجار بشخص آخر له سيطرة عليه، وذلك كله، إذا

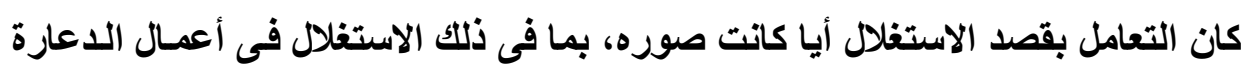

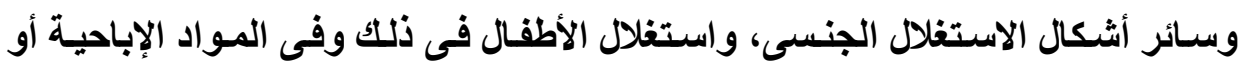

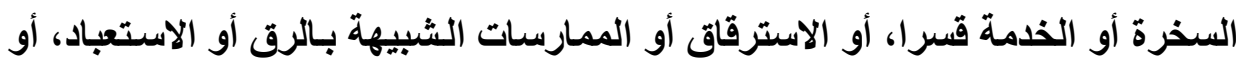

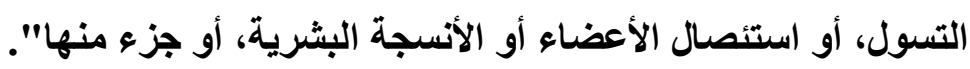
وجدير بالذكر ، أنه طبقا للمادة س من نفس القانون، لا يعتد برضاء المجنى عليه

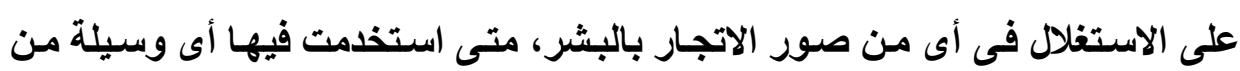

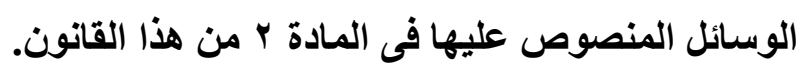

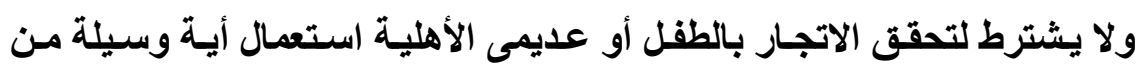

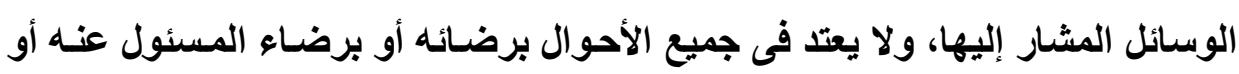

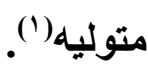

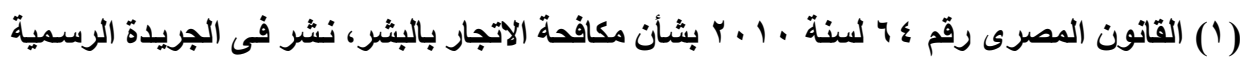

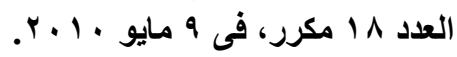

OV 9 مجلت البحوث القانونيت والإقتصاديت 
وتعليقـا على تعريـف الاتجـار بالبشر الـوارد في القـاتون المصرى، نـرى مـع

البعض(') أنه لم يتميز بالإيجاز فى العبارات والمعانى، وإنما جاء مطولا على عكس مـا يفترض فى التعريفات. كما يعتبر تزيدا لا جدوى منه ذكر المشرع فى التعريف أنها يعد مرتكبا لجريمة الاتجار بالبشر كل من يتعامل بأية صورة فى شخص طبيعى، حيث من البديهى أن أفعال الاتجار المعاقب عليها لا يتصور وقوعها إلا على إنسان، أى شخص طبيعى. وعلى الرغم من ذلك الاتتقـاد، إلا أنتـا نـرى مـع البعض الآخر (r) أن التعريف قاء جاء بصورة جامعة، حيث ذكر الوسائل المختلفة للاتجار بالبشر، بل تميز بأنه توسع فى الوسائل بإضافة مصطلحات البيع أو العرض للبيع أو الشراء أو الوعد بهما. وباستقراء تعريف الاتجار بالبشر الوارد فى البروتوكول المكمل لاتفاقية الأمـ المتحدة، وفى التثريع المصرى، وباقى التشريعات الوطنية، نجد أنها جميعـا لم تعتد بموافقة الضحية، أى أن رضاء الضحية على القيام بهذه الأفعال لا ينفى كونها أفعالا غير مشروعة، وذلك لأن إرادة الضحية تكون مقيدة أو منعدمة بسبب لجوء الجانى إلى دهاء استعمال الوسـائل المختلفة، مثل القوة والاحتيـال والخداع وغيرهـا. كمـا اتفقت هذه التشريعات على ضرورة تحقيق غرض غير مشروع فى جرائم الاتجار بالبشر، يتمثل

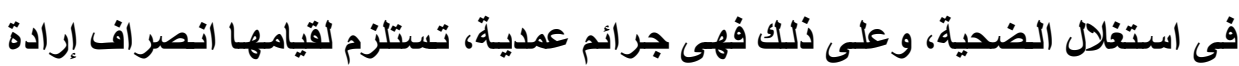
الجانى إلى فعل السلوك، مع علمه بالعناصر الأساسية الأخرى للجريمة.

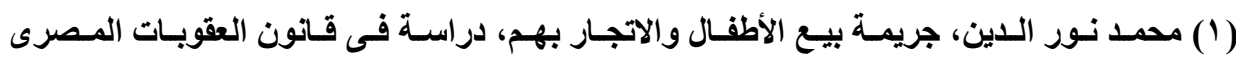

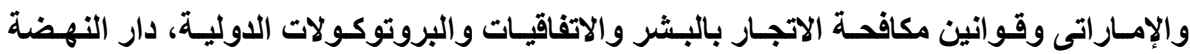

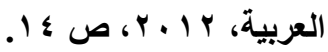
(r) سالم إبراهيم، جرائم الاتجار بالبشر واستراتيجيات مكافحتها على الصعيدين الدولى والإقليمى، دار

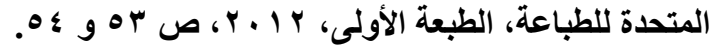

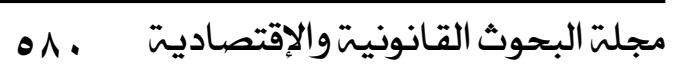




\section{المبحث الثانى}

عناصر الاتجار بالبشر

يتضح من التعريف السابق لجريمة الاتجار بالبشر أنها تتكون من ثلاثة عناصر

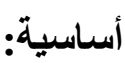

1ـ الفعل: تجنيد أشخاص أو نقلهم أو تنقيلهم أو إيواؤهم أو استقبالهم.

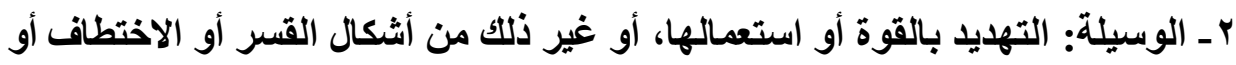

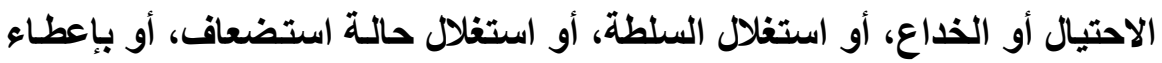

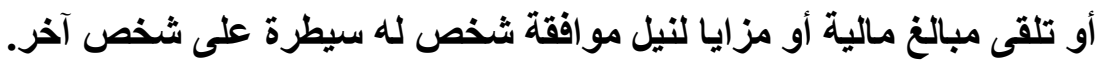

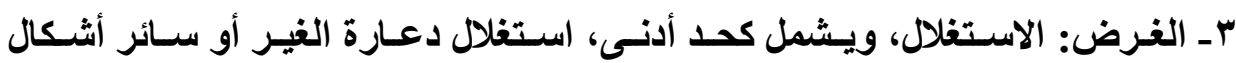

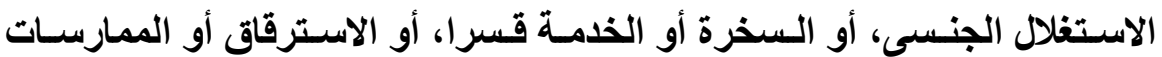

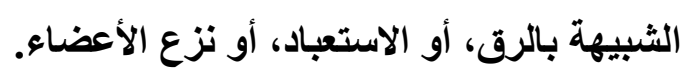

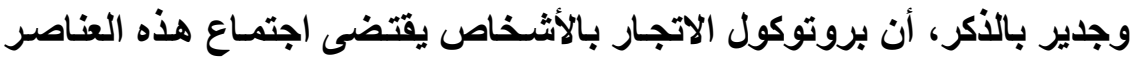

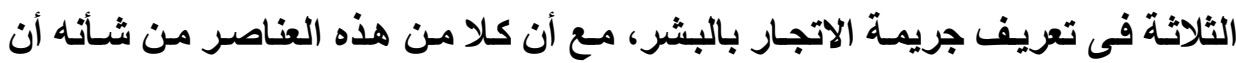

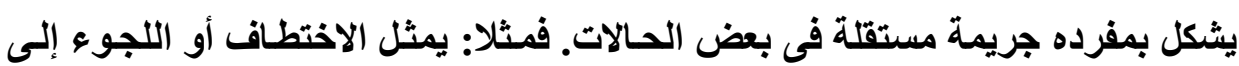
القوة (الاعتداء) فعلين إجراميين منفصلين بموجب التشريعات الجنائية الوطنية' (1).

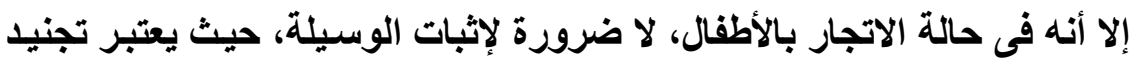

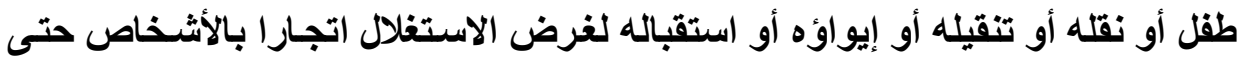

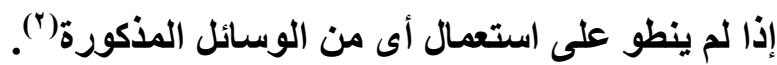

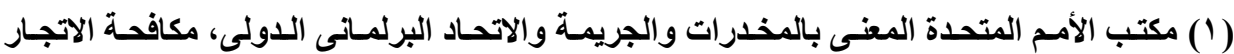

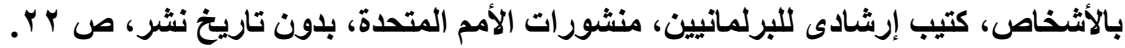

(2) Tonny Moses and Radoslaw Lukasz, Guidelines for assisting victims of human trafficking in the East Africa Region, International=

$$
\text { مجلتة البحوث القانونيت والإقتصاديت }
$$




\section{فكرة رضاء الضحية لا تنفى المسئولية}

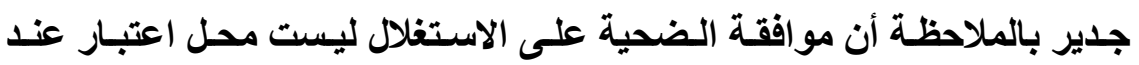

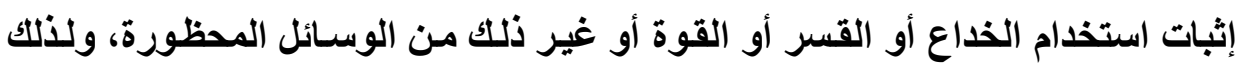

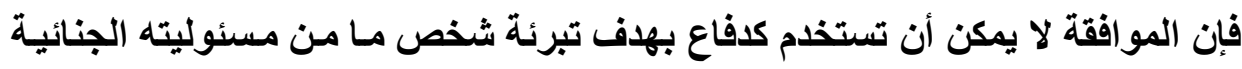

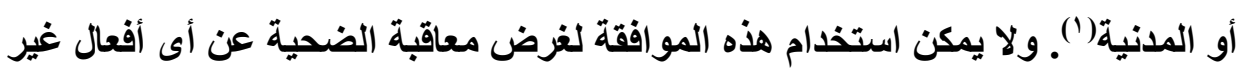

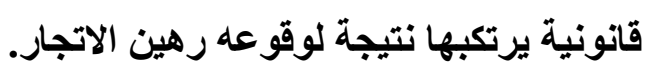
وأخيرا، فإن التعريف الوارد بالبروتوكول يحدد عددا من الأغراض الاستغلالية

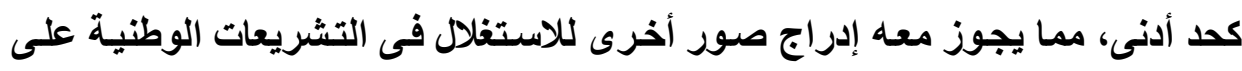

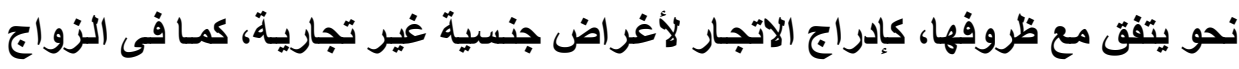

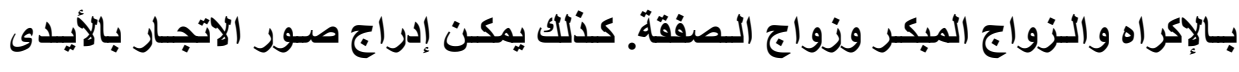

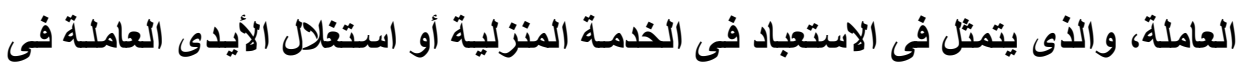

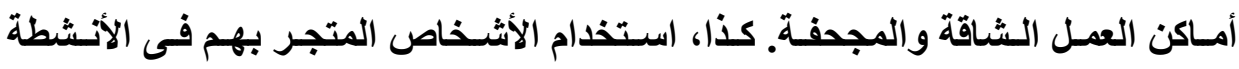

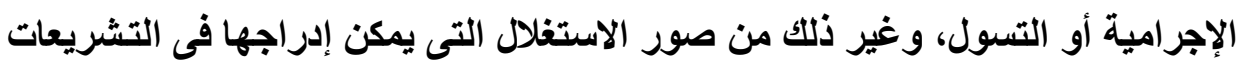

= organization for migration, 2011, P. 18. Also, Marco Gramegna and the EFUS team, Trafficking in Human Beings, International knowledge and local practices in connection with the "Guidance on local safety audits: A compendium of international practice", European Forum for Urban Safety (EFUS), 2007, P. 4.

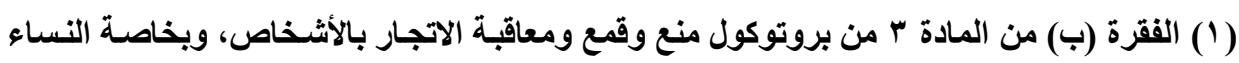

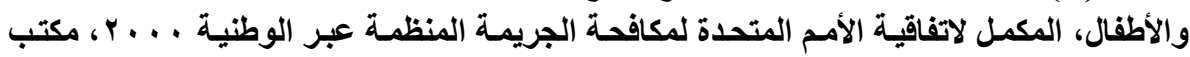

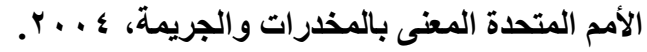

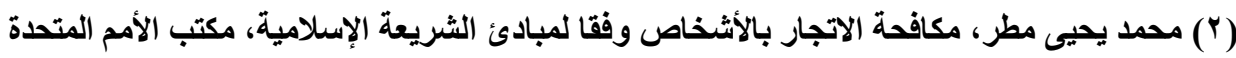

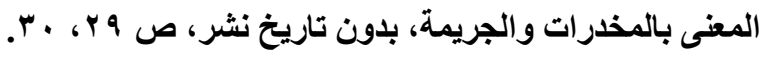

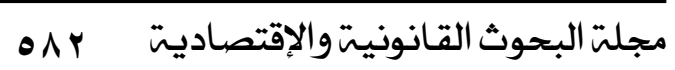




\section{الباب الأول \\ تعويض ضحايا الاتجار بالبشر}

\section{وفقا للقواعد التقليدية للمسئولية المدنية}

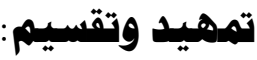

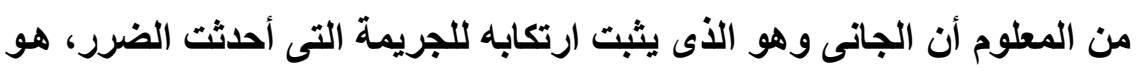

المسئول الأول والأساسى عن تعويض ضحية الجريمة عن الأضرار التى لحقتها'، '). ووفقا للقواعد العامـة التقليدية للمسئولية المدنية، ينبغى لتقرير مسئولية الجانى أن

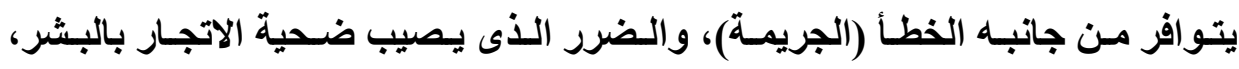
و وعلاقة السببية بين الجريمة والضرر.

وبعد تقرير مسئولية الجانى عن الضرر الذى أصساب ضحية الاتجار بالبشر،

يلتزم بتعويضها عما ألم بها من أضرار مادية ومعنوية. وبناء على ما تقدم، نرى تقسيم هذا الباب إلى فصلين، على النحو الآتى: الفصل الأول: تقرير المسئولية العدنية للجانى فى جريمة الاتجار بالبشر. الفصل الثانى: تعويض ضحية الاتجار بالبشر وعقبات الحصول عليه بالطرق التقليدية.

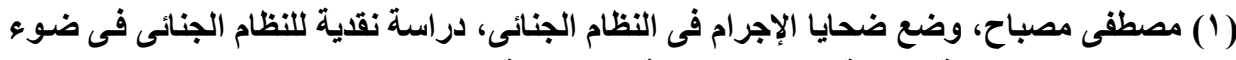

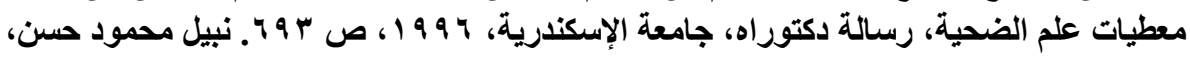

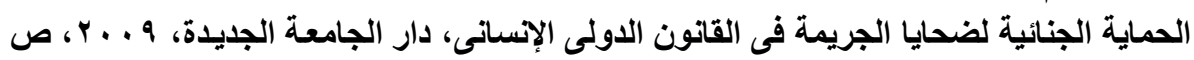




\section{الفصل الأول \\ تقرير المسئولية الملدنية لاجمانى فى جريمة}

الاتجار بالبشر

\section{تمهيد وتقسيم:}

كما قدمنا، الجانى هو من يثبت ارتكابـه لجريمـة الاتجـار بالبشر وفقـا للتعريف الذى ذكرنـاه، وبالتـالى فهو المسئول الأول والأسـاسـى عن تعويض ضـــية الاتجـار بالبشر ، متى توافرت فى حقه أركان المسئولية المدنية.

وبالتـالى، يجب أن يكون مصدر الضرر المؤسس للحق فى التعويض جريمـة بالمعنى المحدد لها فى الفقه الجنائى، باعتبارها عملا غير مشروع يصدر عن الجانى، سواء تمثل فى فعل أو امتـاع، يرتب القانون على وقوعه جزاء جنائيا، يوقع على

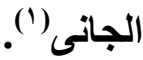

وعلى ذلك، يترتب على ارتكاب أى جريمـة وقوع ضحايا أو متضررين يلحقهم

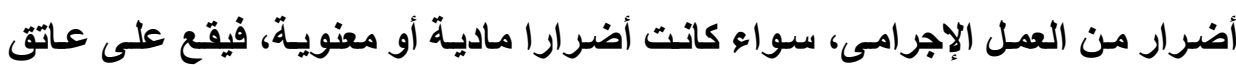
الجناة التزام مدنى بتعويض الضحايا عن الأضرار التى لحقتهم، سواء كاتت مباشرة أو غير مباشرة، ويرجع السبب فى تعويض المضرور إلى وقوع عمل غير مشروع، صدر من شخص (الجانى)، نتج عن هذا الفعل أضرار أصسابت الضحية، وأعطت للمضرور الحق فى التعويض من الفاعل، عن الفعل الذى ارتكبه. 
فالضحية فى جرائم الاتجار بالبشر قد أصابها ضرر، وقع كنتيجة حتمية للخطأ،

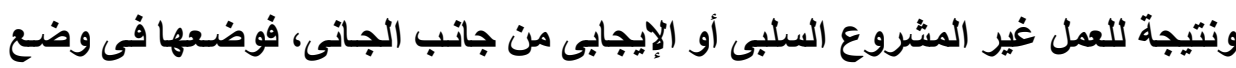

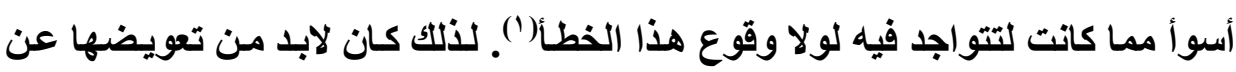
الأضرار المادية والمعنوية التى لحقتها من جراء الجريمة. والجانى فى الجريمة التى نحن بصددها هو المتاجر بالبشر، وهو الثخص الذى

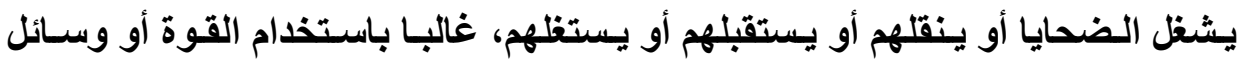

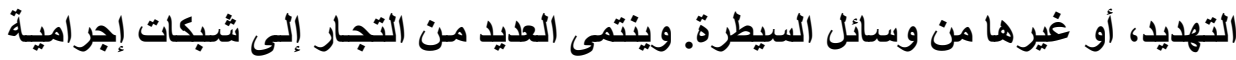

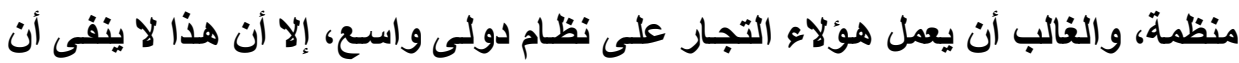

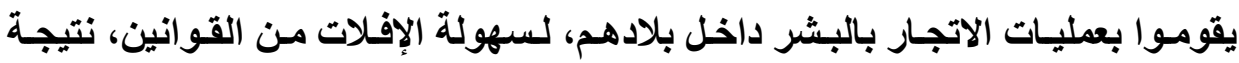

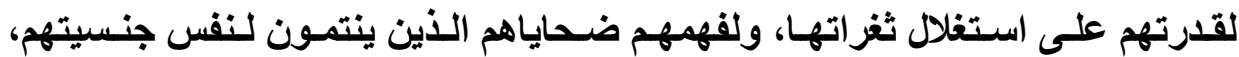
ويالتالى القدرة على استغلالهم (†).

وعلى ذلكك، نص إعلان المبادئ الأساسية لتوفير العالـة لضحايا الجريمـة و إساءة استعمال السلطة على أنه: "ᄉـ ينبغى أن يدفع المجرمون أو الغير المسئولون

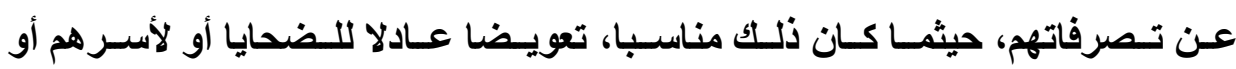

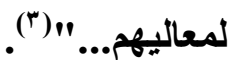

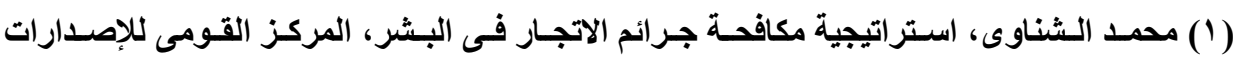

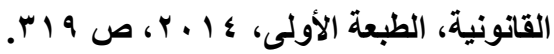

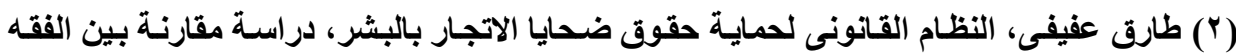

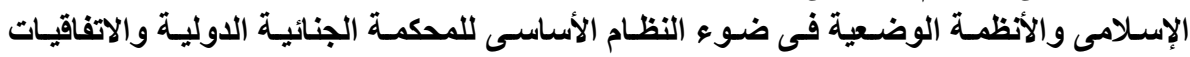

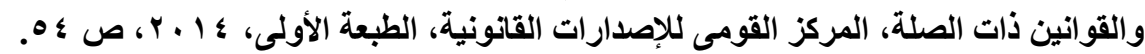

(3) Declaration of Basic Principles of Justice for Victims of Crime and Abuse of Power, Resolution adopted by the General Assembly, November 29, 1985, UN Doc. A/RES/40/34.

$$
\text { مجلتً البحوث القانونيت والإقتصاديت ه1ه }
$$


يتضح من ذلك النص أن الجانى وكل من تسبب فى إحداث ضرر بالضحية يلتزم بالتعويض عن ذلك الضرر. فإذا تعدد الجناة، بحيث تسبب خطأ كل منهم فى إحداث

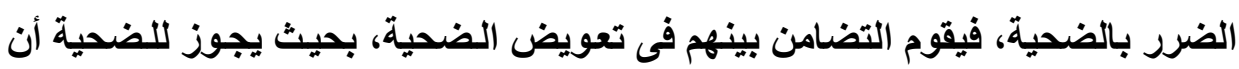
يرفع الدعوى عليهم جميعا، أو على أحدهم، أو بعضهم، ويطالبهم بالتعويض كاملا.

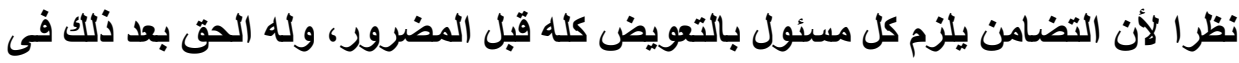

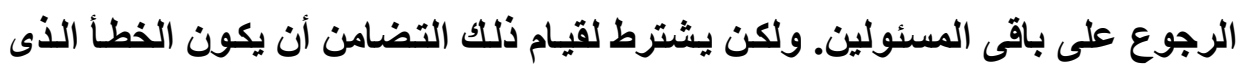

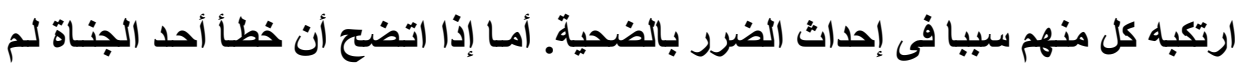
يكن له دخل فى حدوث الضرر، فإنه لا يكون مسئولا مع الآخرين على سبيل التضامن. كما يشترط لقيام التضامن بين الجناة، أن يكون الضرر الذى سبيه كل منهم هو نفس لأله

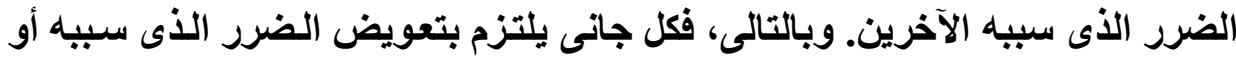
شارك فى إحداثه، ولا شأن له بالأضرار التى حدثت بسبب أخطاء الآن الآخرين.

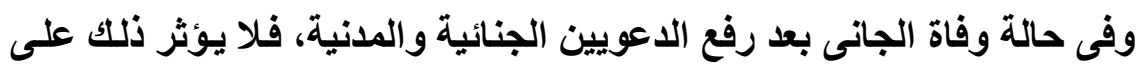
سبير الدعوى الأخيرة، حيث يجوز للمدعى المدنى أن يعلن ورثة الجانى بالاعوى، وأن الجئ يسير فى إجراءاتها ضدهم، بحيث يلتزم الورثة بتعويض الضرر في حدود التركة التى لتى

آلت إليهم. ويتحدد نصيب كل منهم فى التعويض بقدر حصته فى التركة' (') أساس المسئولية المدنية للجانى إن أسـاس مسئولية الجـانى بتعويض ضـايا الاتجـار بالبشر هو المسئولية

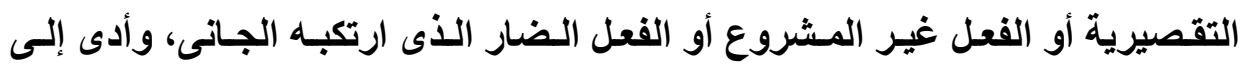
إحداث أضرار جسدية أو معنوية بالضحية.

(1) مصطفى مصباح، المرجع السابق، ص ب 97 وما بعدها.

OAV مجلت البحوث القانونيت والإقتصاديت 
وتقوم المسئولية التقصيرية التى هى أسساس المطالبة بـالتعويض على فكرة

الخطأ والضرر وعلاقة السبيية بينهما. فكل خطأ سبب ضررا للغير يلزم من ارتكبه

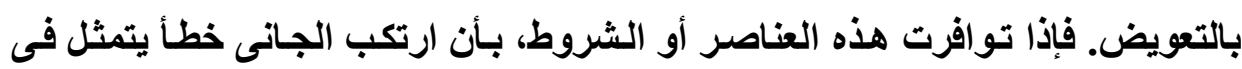
الأعمـال الإجراميـة غير المشروعة، ممـا أدى إلـى إحـاث ضـررا بالـضحية، فيلتزم

$$
\text { بالتعويض. }
$$

وبناء على ما تقدم، نرى تقسيم هذا الفصل إلى ثلاثة مباحث على النحو الآتي:

المبحث الأول: صور الاتجار بالبشر كعمل غير مشروع.

المبحث الثانى: الضرر فى جريمة الاتجار بالبشر.

المبحث الثالث: علاقة السببية بين الجريمة والضرر. 


\section{المبحث الأول}

\section{صور الاتجار بالبشر كعمل غير هشروع}

تتعدد صور وأشكال الاتجار بالبشر، كالعبودية، التسول، العمل الجبرى، الزواج

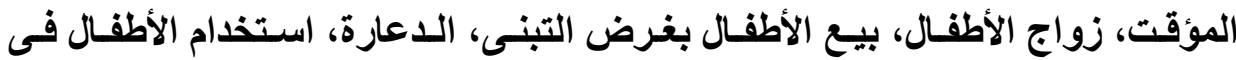

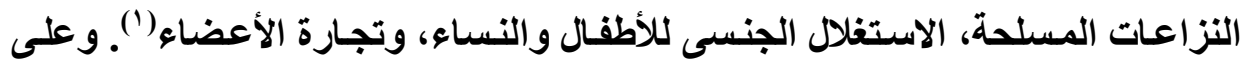
الرغم من أن الاتجار بالبشر لا يقتصر على شكل واحد فقط من أثكال الاستغلال، إلا أنتا سنعرض لصور الاتجار بالبشر الأكثر انتثارا فى مصر ومعظم الدول، والتى تتركز

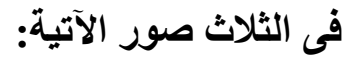

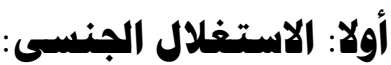

يعد الاستغلال الجنسى مـن أكثر صور الاتجـار بالبشر انتشارا على مستوى

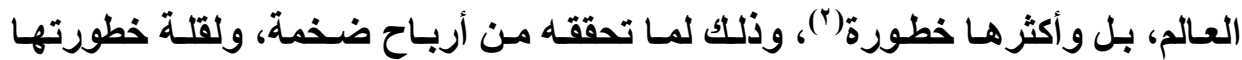
وصعوبة كشفها، هذا فضلا عن الآثار السيئة التى تنتج عنها. وتتمثل ضحية هذه الصورة من صور الاستغلال فى كل من النساء والفتيـات صغار السن، والأطفال من الجنسين(").

( (1) محمد مطر، تثريعات حقوق الإنسان فى العالم العربى، قضية الاتجار بالبشر ، منشور على الموقع الإلكتروني على شبكة الإنترنت:

http://www.protectionproject.org, 2/11/2014

(2) Casey Rubenstein, Aftercare services for international sex trafficking survivors: informing US service and program development in an emerging practice area, Macy and Johns, 2011, P. 4.

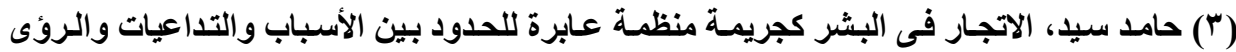

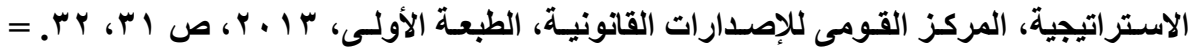

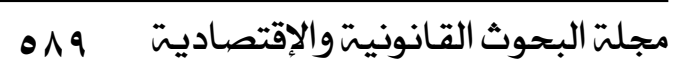


ويشمل الاتجار بالجنس استغلال الغير فى اللاعارة والبغاء، أو غير ذلك من

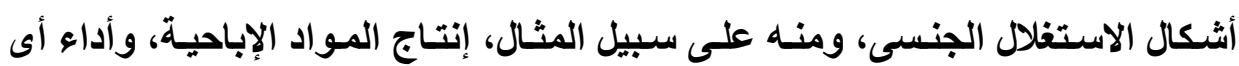

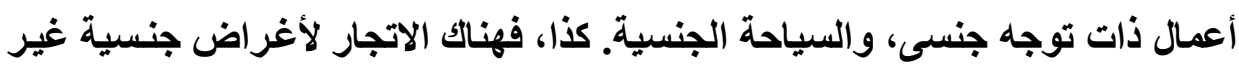

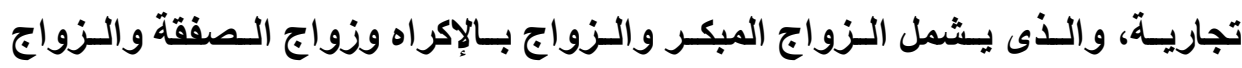

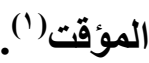

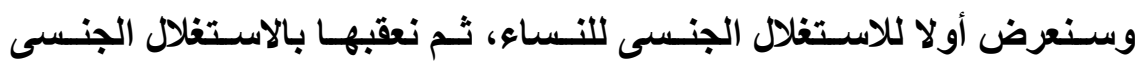
للأطفال، وذلك على النحو الآتى: 1- الاستغلال الجنسى للنساء:

بالنظر إلى عدم وجود تعريف دولى خاص ومحدد للاتجار بالنساء، لذا فتعريفه

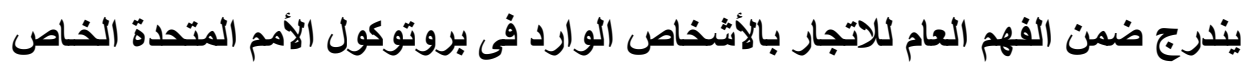

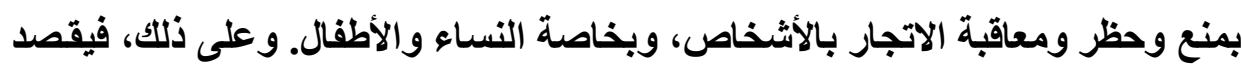

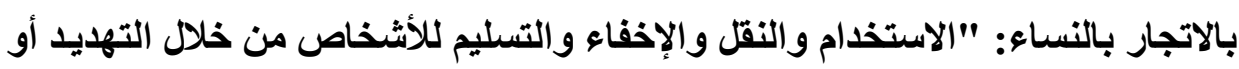

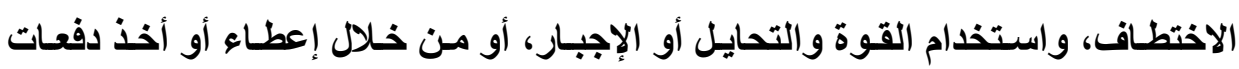

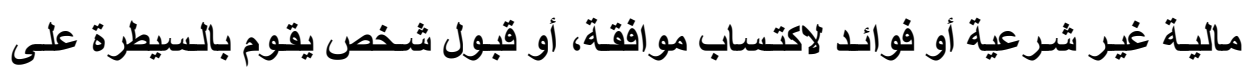

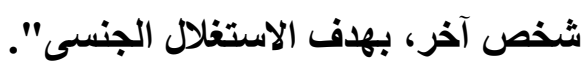

= سعيد أحمد قاسم، شرح قانون الاتجار بالبشر العمانى، دراسة مقارنة بين التشريعات العربية

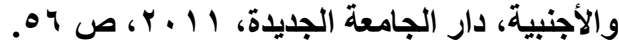

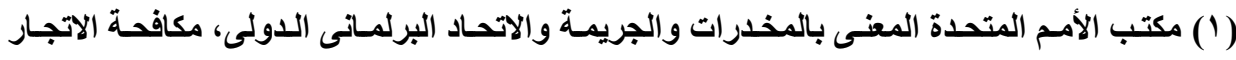

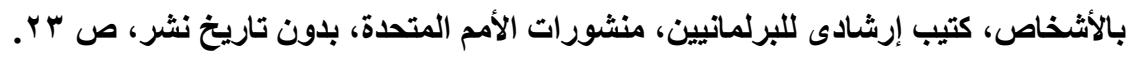

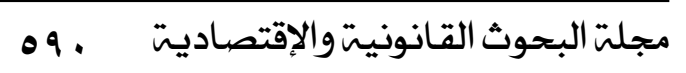


جدير بالملاحظة أن المرأة تعامل فى هذه الصورة من صور الاتجار بالبشر

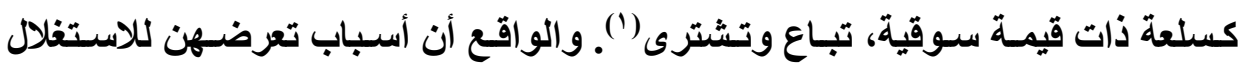

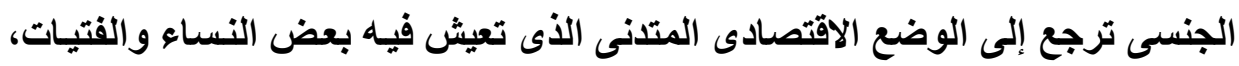

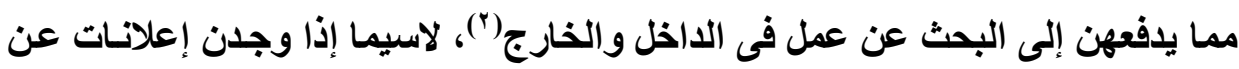

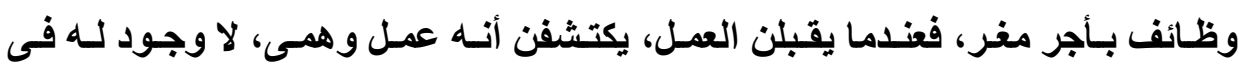

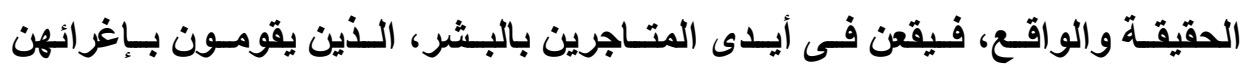
وتهايدهن لاستغلالهن جنسيا، خاصة بعد حجز وثائق سفرهن.

و هكذا، تصبح المرأة ضحية للاستغلال الجنسى، بالتهايد أو الإغراء أو العنف

الذى قد يصل إلى اغتصابها، للقضاء على مقاومتها وإضعاف روحها المعنوية("). وتطبيقا لذلك، حكمت محكمة مقاطعة Pirkanmaa فى Finland فى قضية White \& Case LLP

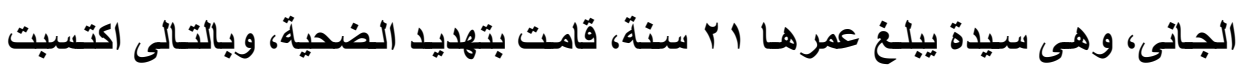

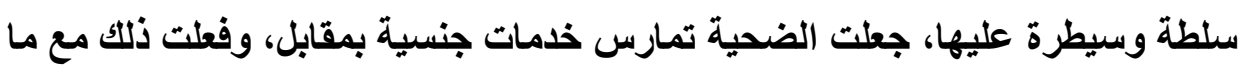
يقرب من مائة عميل، وكسبت مقابل . . 10 يورو، تمكنت المدعى عليها من أخذها

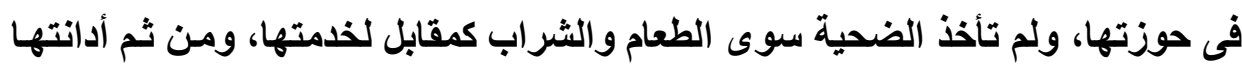

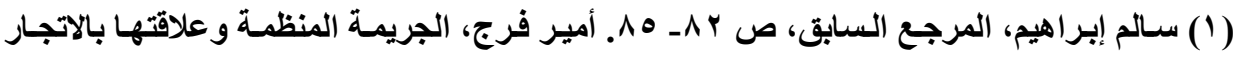

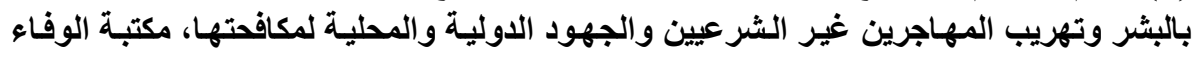

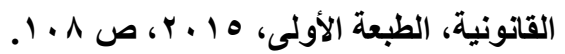

(2) April Rieger, MISSING THE MARK: WHY THE TRAFFICKING VICTIMS PROTECTION ACT FAILS TO PROTECT SEX TRAFFICKING VICTIMS IN THE UNITED STATES, Harvard Journal of Law \& Gender, Vol. 30, No date, P. 235.

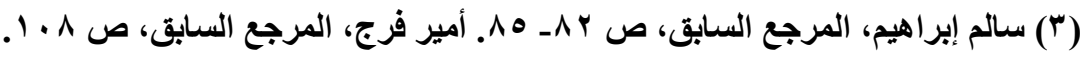

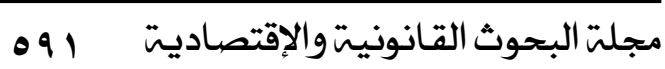


المحكمة بجريمـة اتجـار بالبشر لغرض الاستغلال الجنسى، وحكمـت عليهـا بتعويض الضحية عن الأضرار التى سبيتها هذه الجريمة'(').

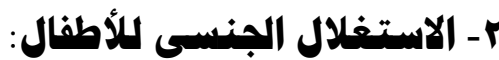

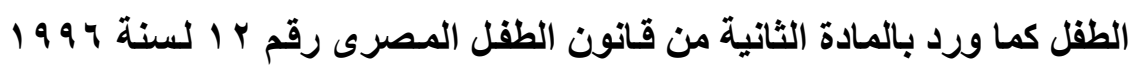

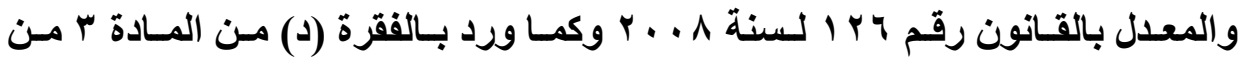
البروتوكول المكمل لاتفاقية الأمم المتحدة لمكافحة الجريمة المنظمـة عبر الوطنية، هو "أى شخص دون الثامنة عشرة من العمر". ويقصد بالاستغلال الجنسى للأطفال: "الاتصال الجنسى بين طقل وشخص بالغ، من أجل إرضاء رغبات جنسية عند الأخير، مستخدما القوة والسيطرة عليه". فالاستغلال الجنسى للأطفال هو اتجار بالبشر، بصرف النظر عن الظروف، فلا توجد أى استثناءات أو تبريرات اقتصادية أو اجتماعية أو ثقافية تمنع إنقاذ الأطفال من

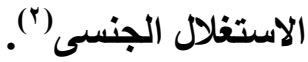
كما قد يتم استغلال الطفل فى المواد الإباحية، ويقصد بها: "استخدام الحاسب الآلى أو الانترنت أو الرسوم المتحركة، لإعداد أو لعرض أو الترويج لأعمال إباحية، تتعلق باستغلال الأطفـال فى الدعارة والأعمـال الإباحية، أو التشهير بهم أو بيعهم، أو لو الو

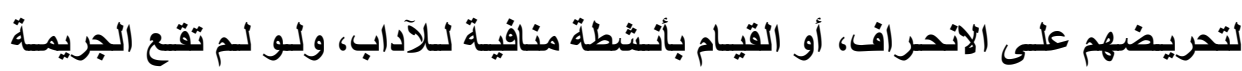

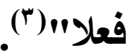

(1) Finland, Pirkanmaa District Court, judgment R 11/1073, Sentence date: 1-11-2011, UNODC No. FIN007.

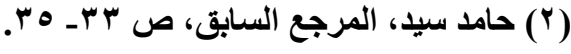

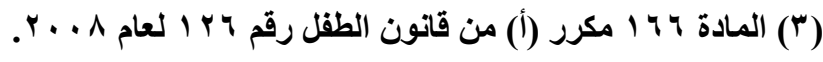

$$
\begin{aligned}
& \text { مجلت البحوث القانونيت والإقتصاديت ب و مه }
\end{aligned}
$$


ونلاحظ أنه غالبا ما يكون الجـانى أكبر سنا من الضحية، ويتم استغلال الطفل عن طريق: التودد أو الترغيب، من خلال استخدام الرشوة والملاطفة وتقديم الهدايا، أو التهديد والترهيب والتخويف من إفشاء السر أو الكشف عن الاعتداء، وذلك عن طريق الضرب، التهديد بـالتوقف عن عمل أشياء للطفل اعتـاد عليها، كـالخروج للنزهـة أو شراء حلويات. وما يزيد الأمر خطورة هو أن هذا الاعتداء يتم فى سرية كاملة، حيث يقوم الجانى بإقناع أو ترهيب الطفل بضرورة إخفاء الموضوع وعدم الإفصاح عنه، ويلاحظ أنـه نـادرا مـا يستخلم الجـانى العنف مـع الضحية، خوفـا من أن يترك علامـات

$$
\text { وآثار ظاهرة على الجسم، فينكشف أمره(') }
$$

ولا يقتــر الأمـر على ذلــ، بـل يمتـــ إلى السياحة لممارسـة الجنس مـع الأطفال(؟)، حيث يسافر الثخص من بلده، والتى غالبا ما يكون ممنوعا فيها الاستغلال الجنسى للأطفال، مما يشكل اعتداء فاضحا، و إسـاءة فظيعة لكرامـة الأطفال، ممـا يؤدى إلى تداعيات مدمرة، قد تشمل صدمات جسدية ونفسية تستمر طويلا، والمرض كالإيلز، وإدمان المخدرات، والنبذ من المجتمع، بل والموت أحيانا"(").

\section{ثانيا: العمل الببرى (السخرة):}

يقصد بالعمل الجبرى (السخرة): " كل أعمال أو خدمات تغتصب من أى شخص

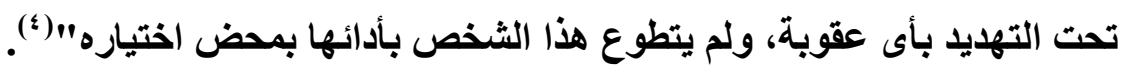

$$
\text { (1) سالم إبراهيم، المرجع السابق، ص بq. }
$$

(2) Mohamed Y. Mattar, Trafficking in Persons: An Annotated Legal Bibliography, Law Library Journal, Vol. 96:4, 2004, P. 694.

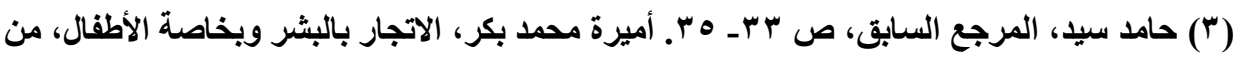

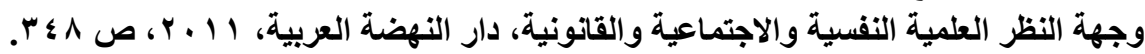

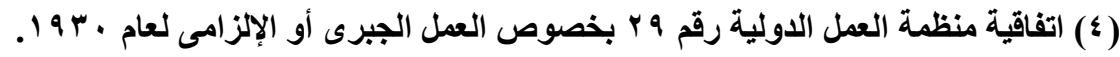

$$
\text { مجلت البحوث القانونيت والإقتصاديت به هـ }
$$


وتتمثل هذه الصورة مـن صور الاتجـار بالبشر في أن العديـ مـن المهاجرين لأسباب اقتصادية، ممن يتركون منازلهم فى مجتمعات نامية، ويسافرون مسافات بعيدة

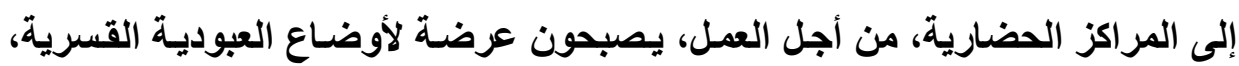

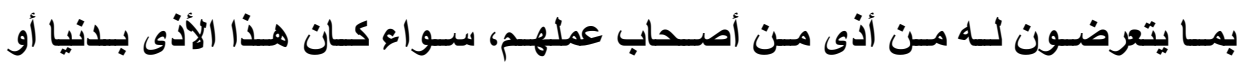
لفظيا، وكذلك خرق عقد العمل الذى قد يتخذ شكل تـأخير الأجور، أو عدم إعطاء أجازة للراحة من العمل، بل هناك من يصل استغلاله إلى حد اعتبـار أنها محتجز عند صـاحب

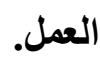
وقد يأخذ العمل الجبرى عدة أشكال أو صور منهـا: العمل المقيد وهو أحد

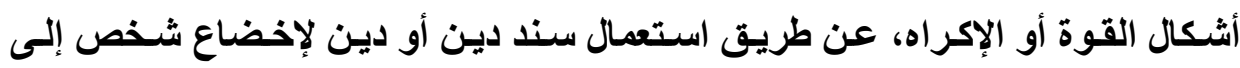
الاستعباد، فيما يسمى أيضا بعبودية الدين. ويقع الكثير من العمال ضحايا عبودية الدين، عندما يستثل المتاجرون بالبشر أو وكالات التوظيف، بشكل مخـالف للقانون، دينـا أخذه العامل على عاتقهـ كجزء من شروط توظيفه. وتكمن الصورة الثانية فى الاسترقاق المنزلى، حيث يمكن أن يقع خدم المنـازل

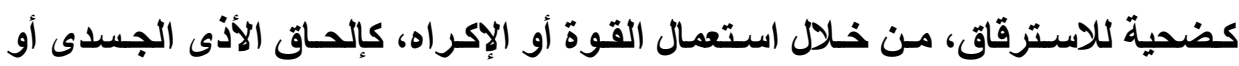
المعنوى، وبخاصة الأطفال. ويلاحظ أنه غالبا ما يصعب اكتثاف حالات الاسترقاق المنزلى، لأنها تحدث فى منــازل خاصـة لا تخضع فـى معظم الأحـوال للتنظيم أو الرقابـة مـن جانـب السلطات 
وتطبيقا لهذه الصورة، فى الولايـات المتحدة الأمريكية، حكم على عبد الناصر

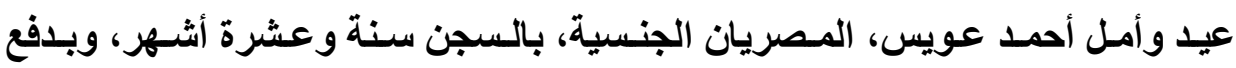

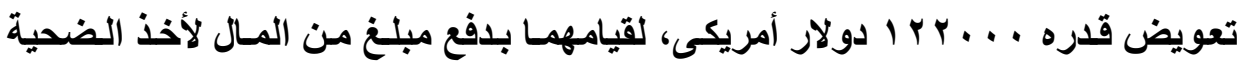
التى كانت فتاة تبلغ من العمر ^ أعوام إلى أمريكا، واستخدما فى ذلك التهايد بالإدعاء التهاء كذبا على أختها التى كانت تعمل لديهم بالسرقة وتسليمها إلى الشرطة، وبالفعل سـافرت الفرات

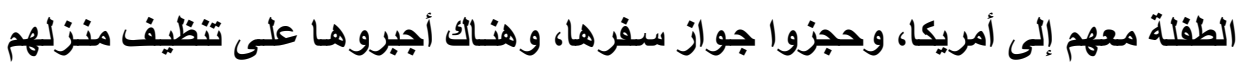

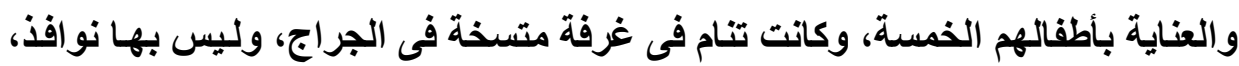

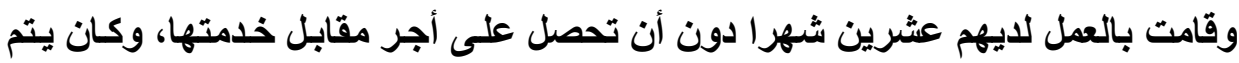

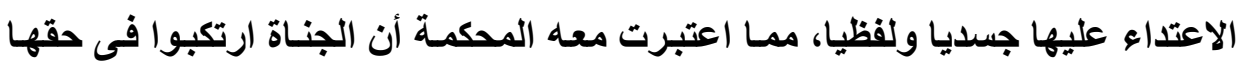

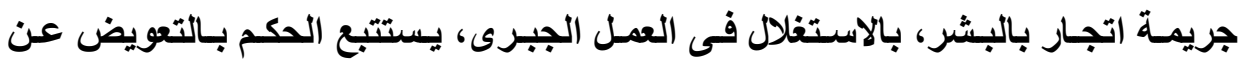
الأضرار التى لحقت الضدية) (1)

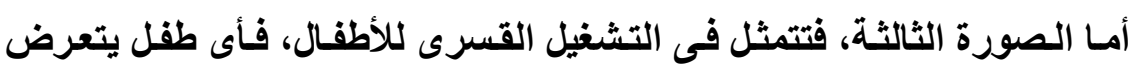

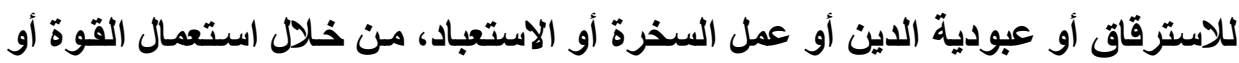

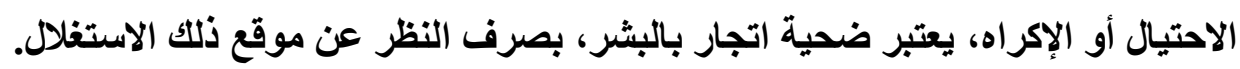
وتتمثل الصورة الأخيرة فى تجنيد الأطفال، والذى يعتبر مظهرا خطيرا للاتجار

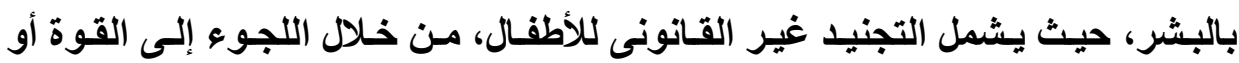
الاحتيال أو الإكراه، لاستغلالهم فى العمل، أو لإسـاءة معاملتهم كعبيد لممارسة الجنس الجنس

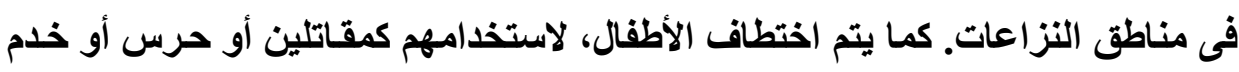

(1) United States Of America V. Abdel Nasser Yossif, UNODC No. USA037, Available at: http://www.justice.gov/usao/cac/pressroom/ pr2006/089.html, 15/10/2014

مجلت البحوث القانونيت والإقتصاديت هو 
أو جواسيس. كمـا تجبر الفتيات على الزواج أو على ممارسـة الجنس مـع المقاتلين، ويتعرضون للاغتصاب، واكتساب الأمراض التى تنتقل بممارسة الجنس (').

وفى هذا الخصوص، نذكر قضية بيتر (ro سنة) وكيفن (9 (19 سنة)، وهما

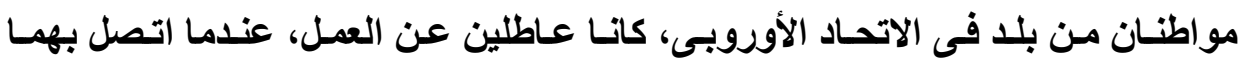

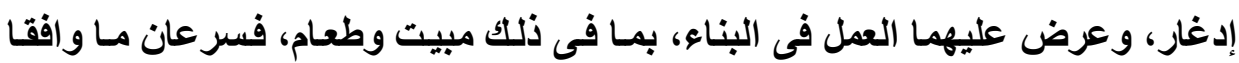

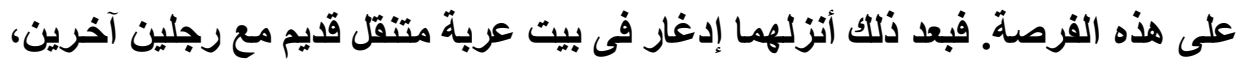

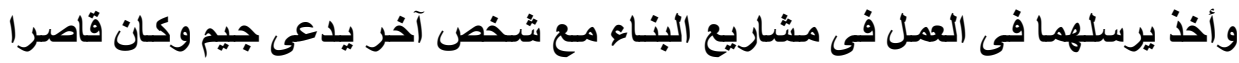

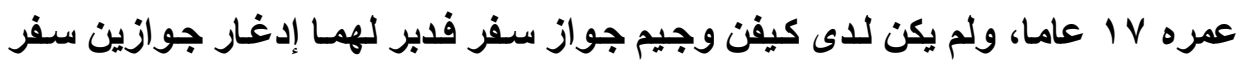

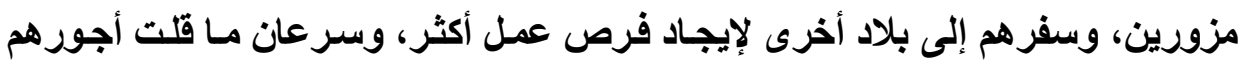

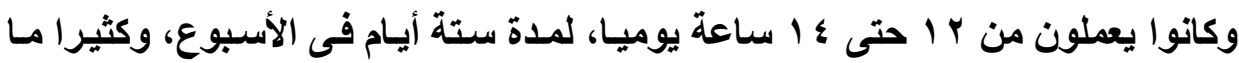

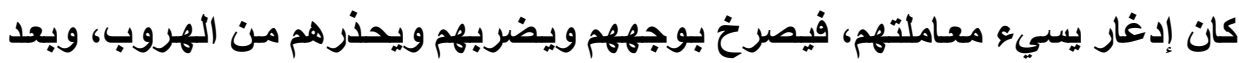

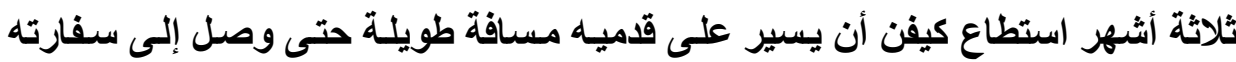

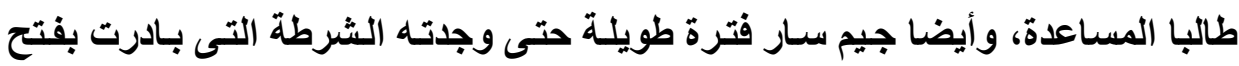

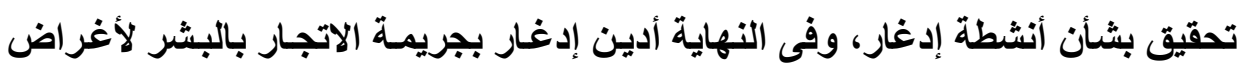

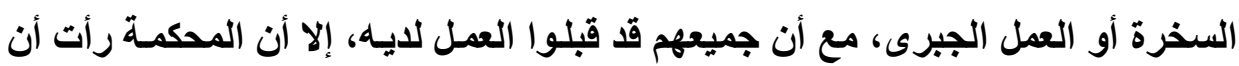

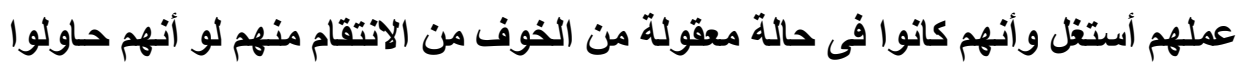
ترك عملهم، وقدرتهم المحدودة على التعبير عن أنفسهم بلغة البلد وأوراق الهويـة

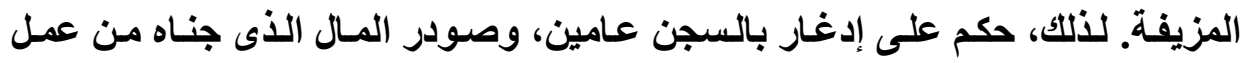
البناء، وطولب بدفع تعويضات عن الضرر بقيمة قدرها أجور عشرة أيام عمل (').

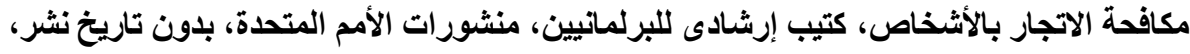


وأيضا فى قضية Ranya Boonmee, Kaew Kongmuang and فئ تايلاند حكمت المحكمة الجنائية فى Banus Boonmee

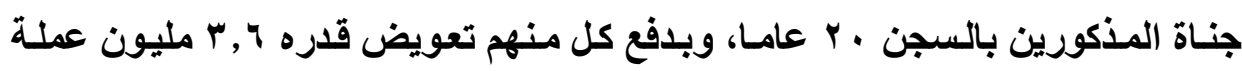

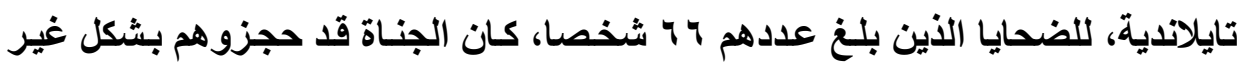

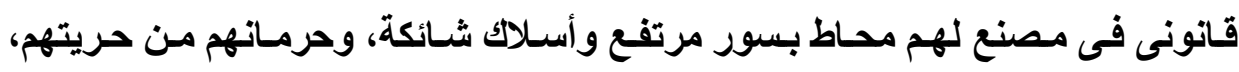

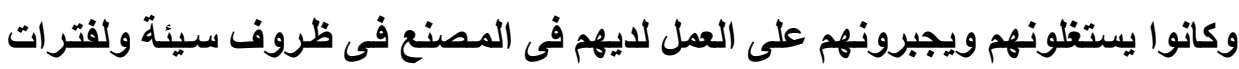

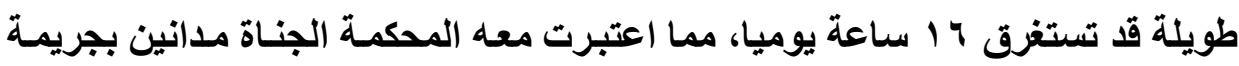

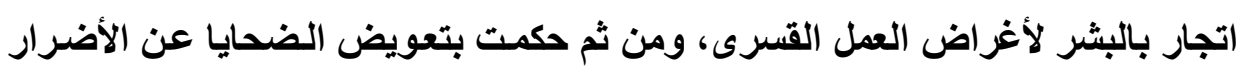
التى لحقتهم، وعن الأجور التى حرموا منها فى مقابل العمل (').

\section{ثالثا: الاتجار فى الأعضاء البشرية:}

يشير بروتوكول الاتجـار بالأثخاص صراحة إلى اعتبار الاتجار بالأثخاص

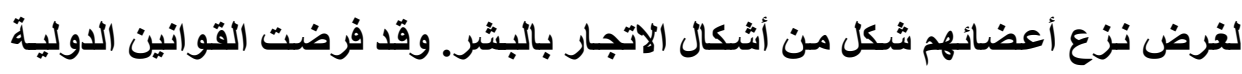

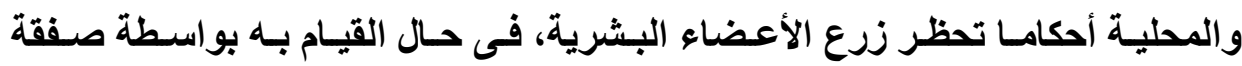
تجارية، أو من دون رضا المانح.

وينـاء على ذلكى، فقد نص المبدأ التوجيهى الخـامس مسن مشروع المبـادئ

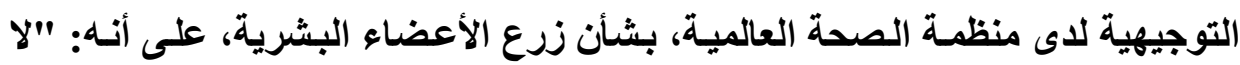

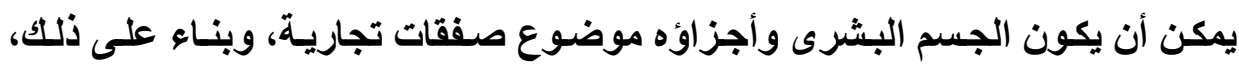

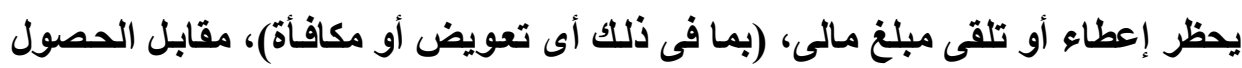
على أعضاء")(')

(1) Thailand, Criminal Court Case No. 2013/2552. Red Case No. 4154/2553, Date of decision: 9-12-2010, UNODC No. THA001.

(Y) منظمـة الصحة العالميـة، مسشروع المبـادئ التوجيهيـة بـثأن زرع الأعضاء البشرية، المبـدأ

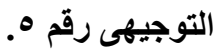

مجلم البحوث القانونيت والإقتصاديت 
وقد جاء فى التعليق على هذا المبأ، أن: "القصد من هذا المبدأ، حظر الاتجار

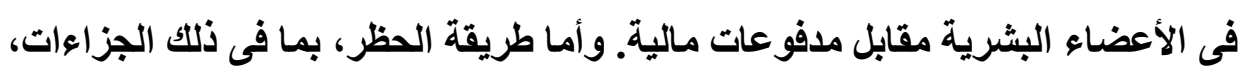

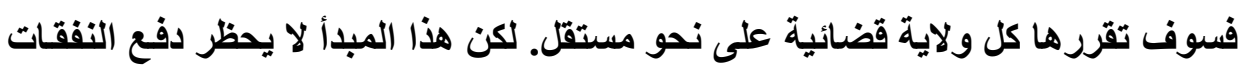

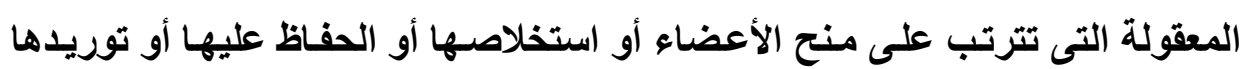

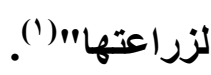
إذن، فيمكن تعريـف جريمـة الاتجـار بالأعضاء البشرية بأنها: "قيـام فـرد

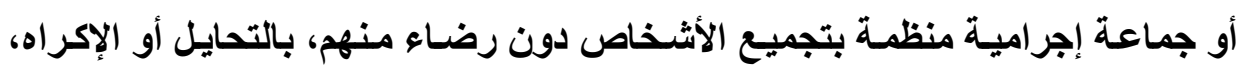

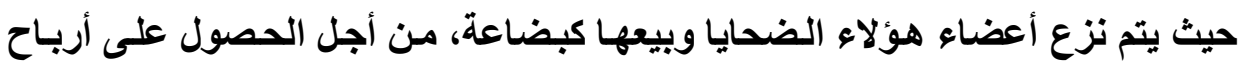

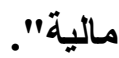
و وعلى ذلك، فمحل الجريمة هنا هو أعضاء جسم الإنسان ذاتها، فتتحول بذلك فى يد تاجر البثر إلى مجرد سلعة تباع وتثثترى. يتضح من ذلك، أن جريمة الاتجار فى الأعضاء البشرية يتمثل ركنها المادى فى إحضار الأثخاص ونقلهم من دولة المصدر، واستقبالهم وإيو ائهم فى دولة المقصدي،

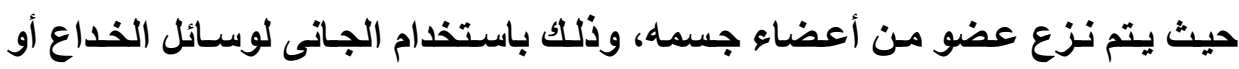

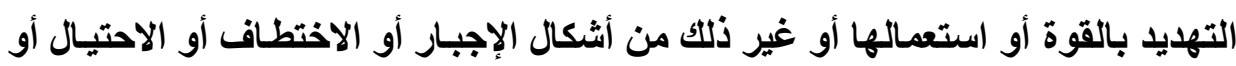

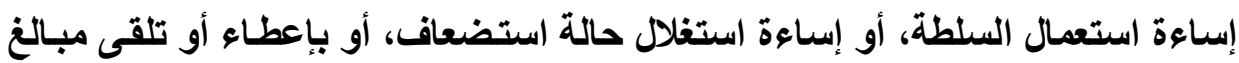

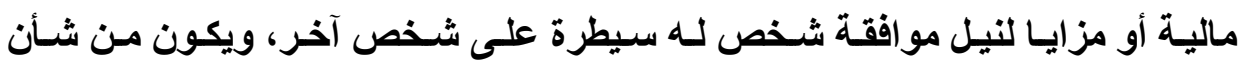
استخدام أى وسيلة من ذلك، أن أعدمت إرادة الضحية، فلا يكون الانتزاع برضائه.

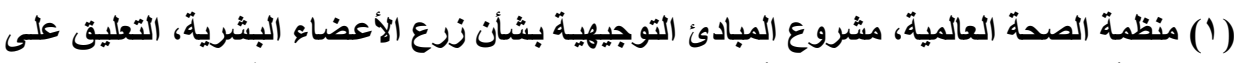

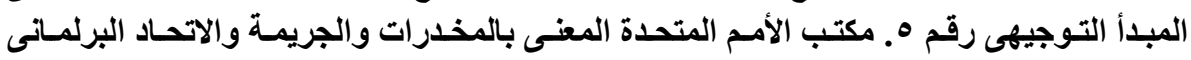

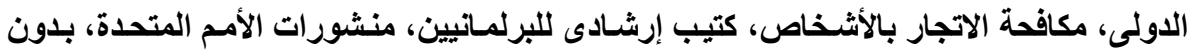

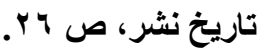

$$
\text { مجلتة البحوث القانونيت والإقتصاديت 9 هـ }
$$


أما الركن المعنوى، فيتمثل فى ضرورة أن تتجها إرادة الجـانى إلى فعل الاتجـار بالأعضاء البشرية عالما بكافة عناصرها، فضلا عن اتجاه إرادته إلى استغلال الإنسان بنزع أعضائه، من أجل الحصول على أرباح مالية(')

إذن، فهنـاك فرق واضـح بين نقل وزراعـة أعضاء البشر ، وجريمـة الاتجـار

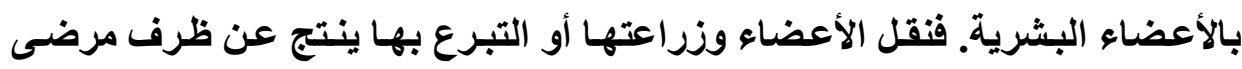
خطير. أمسا مفهوم نزع الأعضاء والاتجار بها مختلف تمامـا عنه، حيث أنه استغلال

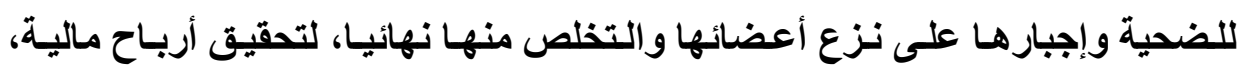

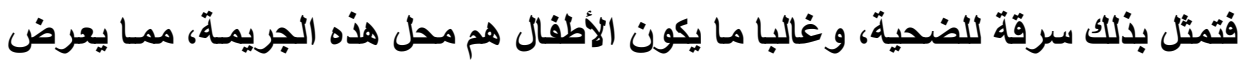

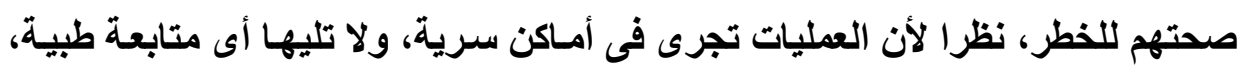

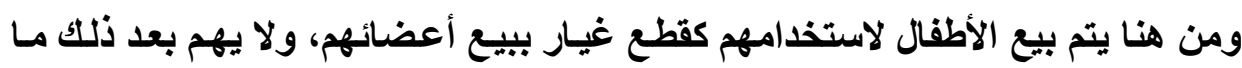
يحدث للطفل أثناء العملية أو بعدها، بل غالبا ما يتم التخلص منهم (ب).

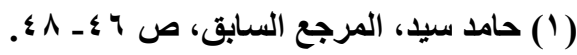

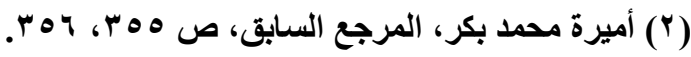

$$
\begin{aligned}
& \text { مجلت البحوث القانونيت والإقتصاديت و 9 9 }
\end{aligned}
$$




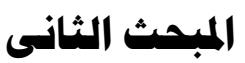

\section{الضرر فى جرييمة الاتجار بالبشر}

الضرر شرط أساسى لاستحقاق التعويض، والضرر هو كل أذى يصيب الإنسان

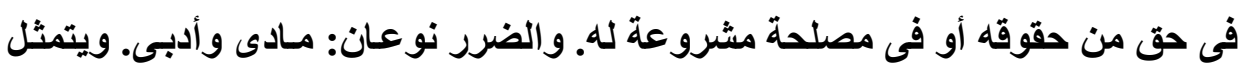

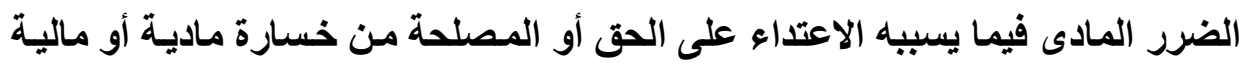

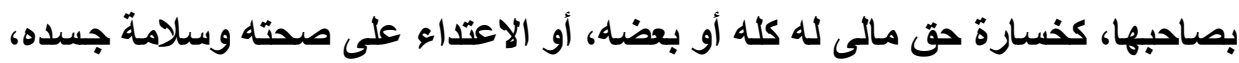

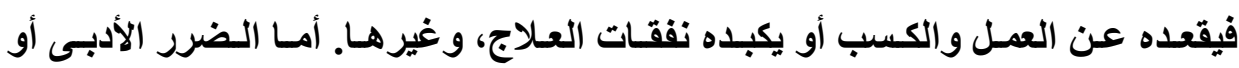

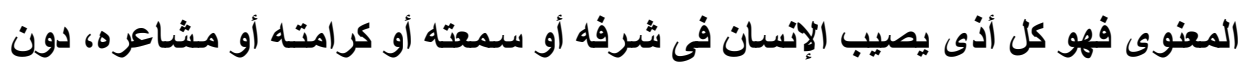

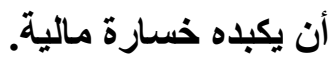

ولا شـك فـ أن جرائم الاتجـار بالأثـخاص غالبـا مـا تحـدث كـلا النـوعين مـن

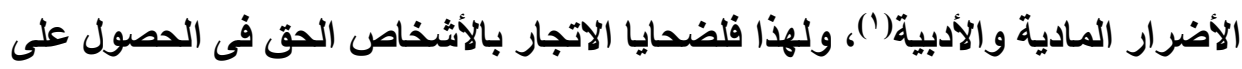

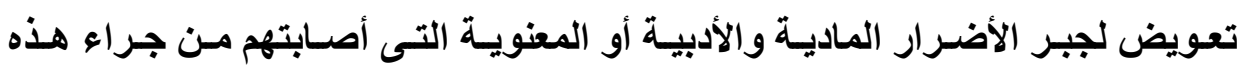

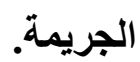

وعلى ذلك، نصت المادة V من القانون النموذجى لمكافحة الاتجار بالأشخاص

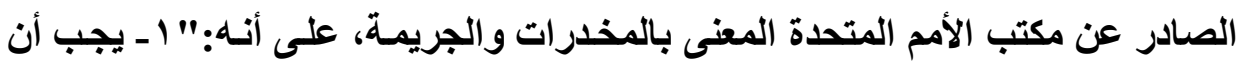

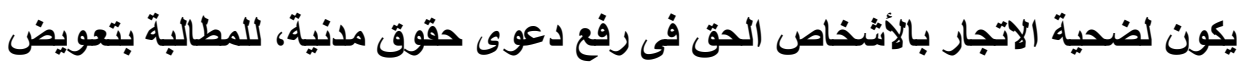

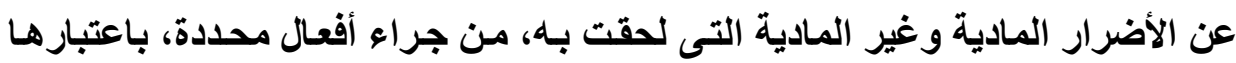

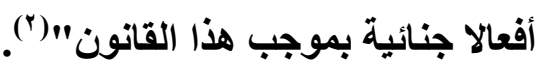

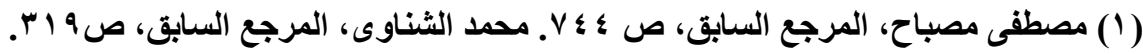

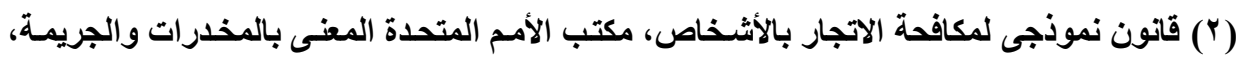

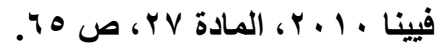

مجلت البحوث القانونيت والإقتصاديت ا ـ 
وقد عرف القانون المصرى رقم ع \ لسنة ـ 1 ـ ب بشأن مكافحة الاتجار بالبشر

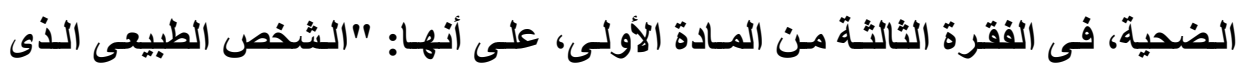

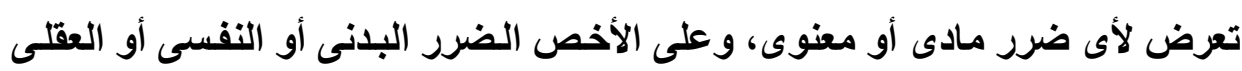

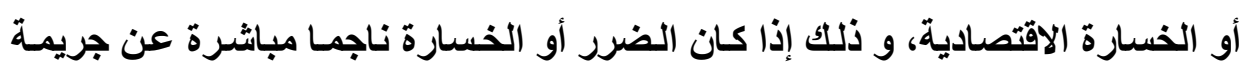

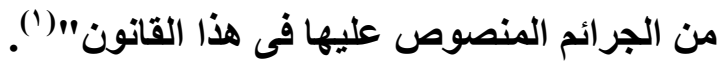

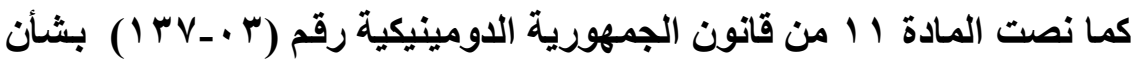
تهريب المهاجرين المخالف للقانون والاتجار بالأشخاص، على أن: "تستخدم العائدات المتأتية من الغرامـات على جرائم الاتجار لأجل تعويض ضحايا الاتجـار عن الأضرار

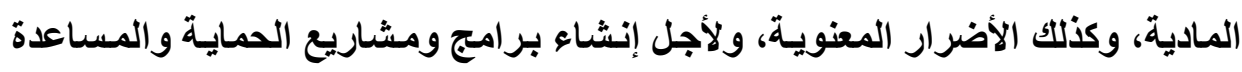

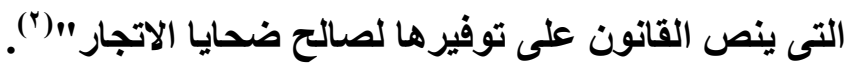
ونبين أنواع الأضرار التى تصيب ضحية الاتجار بالبشر، والتى يجب أن يعوض عنها، وذلك على النحو الآتى:

\section{أنواع الأضرار الناتجة عن جرييمة الاتجار بالبشر:}

يصيب ضحية الاتجار بالبشر نوعين من الأضرار يجب التعويض عنهما، وهما:

1 - الأضرار المادية

ينبغى أن يحصل ضحايا الاتجار بالأشخاص على تعويض عن جميع الأضرار والخسائر المادية التى لحقتهم من جراء الاتجار بهم أو استغلالهم.

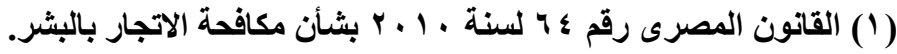

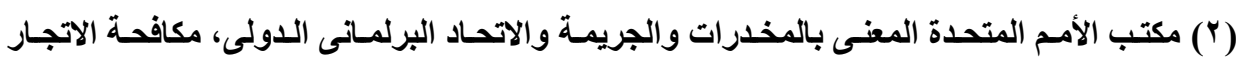
بالأثخاص، كتيب إرشادى للبرلمانيين، منشورات الأمم المتحدة، بدون تاريخ نشر ، ص 9 هـ 
فأولا، يجب أن تحصل الضحية على تعويض عن الأضرار أو الإصابات الجسدية

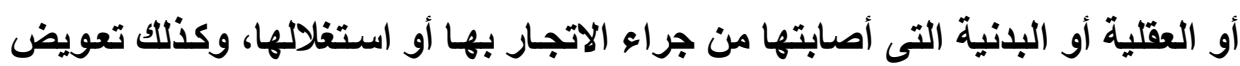

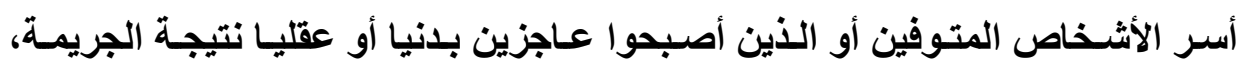
وبصفة خاصة من كانوا يعتمدون فى إعالتهم على هؤلاء الأثخاص.

وعلى ذلك نصت المادة r ا من إعلان المبادئ الأساسية لتوفير العدالة لضحية

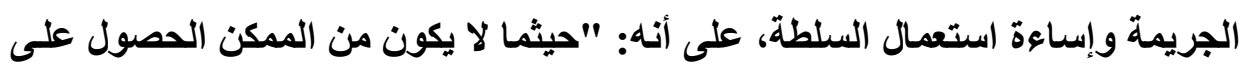
تعويض كامل مـن المجرم أو من مصادر أخرى، ينبفى للـاول أن تسعى إلى تقديم تعويض مالى إلى: - تعزئ

أ ـ الضحايا الذين أصيبوا بإصابات جسدية بالغة أو بـاعتلال فى الصحة البذنيـة أو

$$
\text { العقلية نتيجة لجرائم خطيرة. }
$$

بـ أسـر الأثـخاص المتـوفين أو الذين أصبحوا عـاجزين بـنيا أو عقليـا نتيجـة

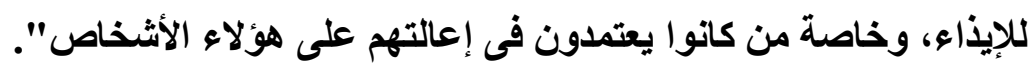
وكما قدمنا من قبل، بمناسبة الكلام عن التعويض لرد الحقوق، "فينبغى أن يدفع

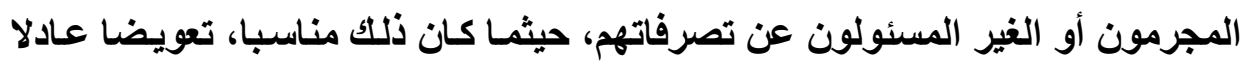

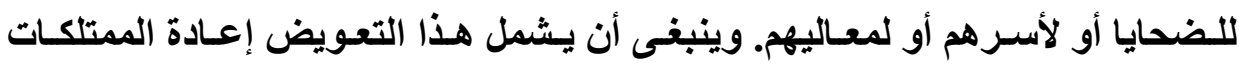

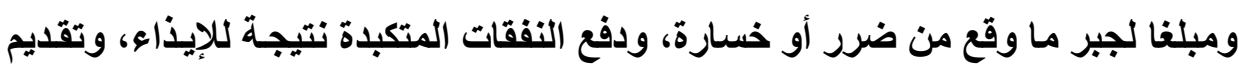

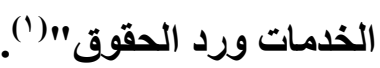

(1) Declaration of Basic Principles of Justice for Victims of Crime and Abuse of Power, Resolution adopted by the General Assembly, November 29, 1985, UN Doc. A/RES/40/34.Articles 12 and 8. 
كذلك بينت المادة ^ Y من القانون النمونجى لمكافحة الاتجار بالأثخاص أمثلة

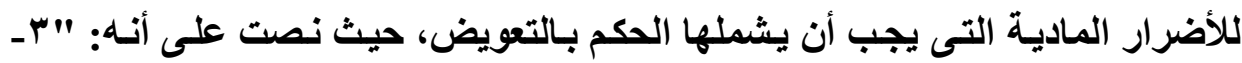

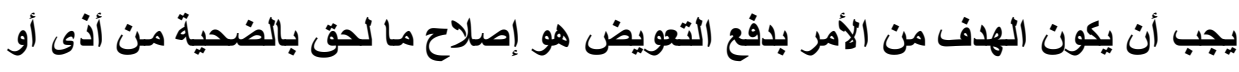

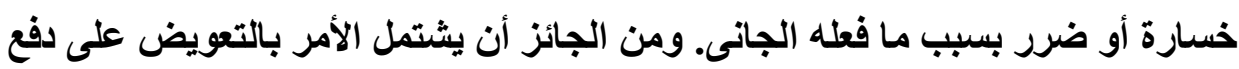

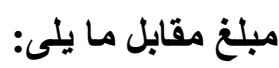

أ ـ تكاليف المعالجة الطبية أو الجسدية أو النفسية أو العقلية اللازمة للضحية.

بـ تكاليف العلاج الجسدى أو المهنى الطبى أو إعادة التأهيل اللازمة للضحية.

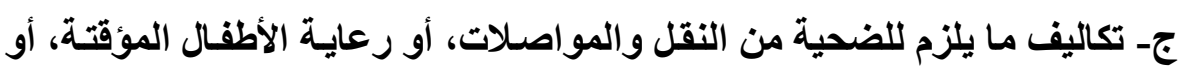
السكن المؤقت، أو نقل الضحية إلى مكان إقامة آمن مؤقت.

دـ ـ فقدان الــلـل والأجـور المستحقة وفقـا للقـانون الـوطنى واللـوائح التنظيميـة

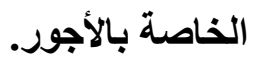

هـ الرسوم القانونية وغيرها من التكاليف أو النفقات المتكبدة، بما فى ذلك التكاليف

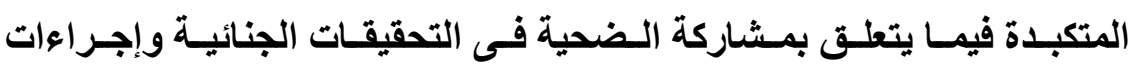

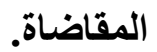

و- .... ز- أى تكاليف أو خسائر أخرى تكبدتها الضحية كنتيجة مباثرة لخضوعه

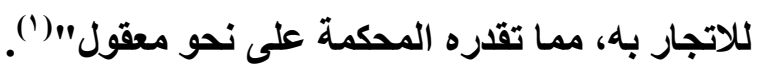

إذن، الأضرار الماديـة يمكن أن تكون ذات قيمـة ماليـة، وتكون نتيجة مباشئهرة

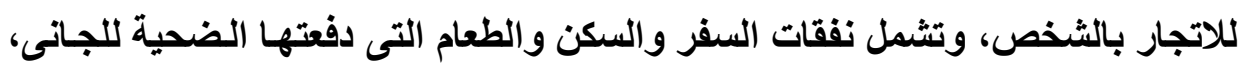

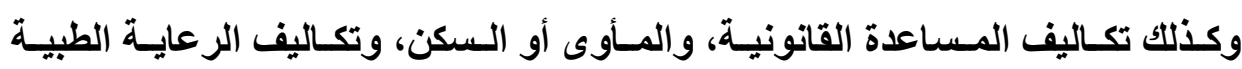

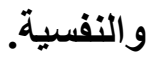

(1) قانون نمونجى لمكافحة الاتجار بالأشخاص، مكتب الأمم المتحدة المغى بالمخدرات والجريمة،

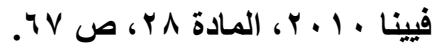

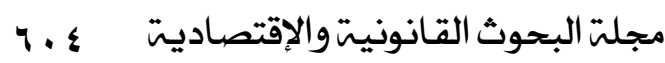




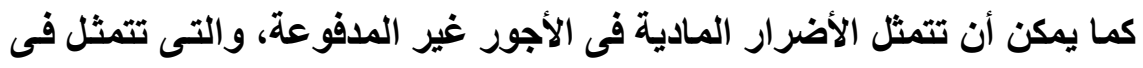
مقابل أو أجر الذدمات والعمل الذى قدمته الضحية للجانى، ولم يأخذ أجر كمقابل لها أو الو الوكي جزء منه. وأيضا الاخل الذى حصل عليه الجانى من الضحية مقابل استغلالها فى أعمال البغاء.

وتطبيقا لذلك، حكم فى قضية Fermin Pedro وهو الجانى ضد J.D وهى

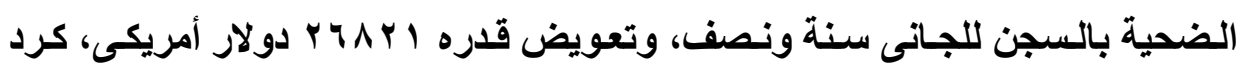

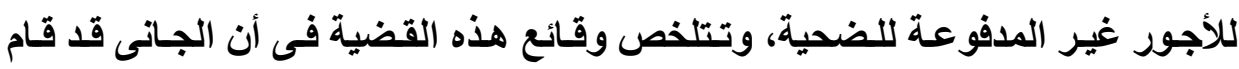

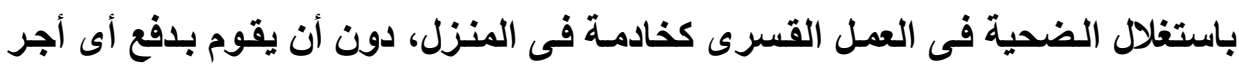
لها، واستخدم فى ذلك وسائل تهايد وعنف بدنى من أجل السيطرة عليها، كما أخذ منها

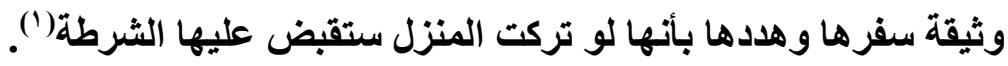

ويعتبر من قبيل الخسائر والأضرار المادية أيضا، الأموال التى أخذها الجانى من

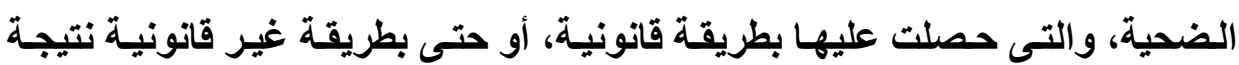

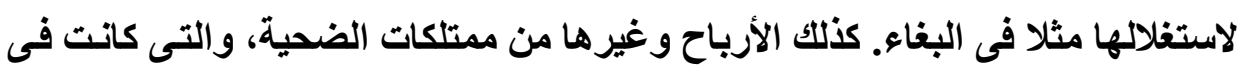

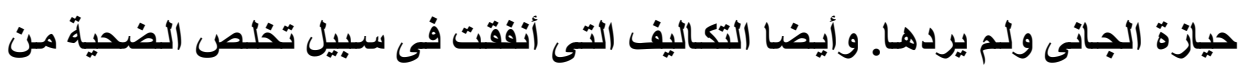
وضع الاتجار بها أو استغلالهاب().

(1) United States Of America, United States District Court for the Western district of Michigan, Sentence date: 24-10-2007. Available at: https://www.law.umich.edu/clinical/HuTrafficCases/ Pages/CaseDisp.aspx? caseID=99

(2) Comp. act, European Action for compensation for trafficked persons, Guidance on representing trafficked persons in compensation claims, A practical tool for lawyers, counselling centers and service providers, toolkit on compensation for trafficked persons, No Date, P. 6.

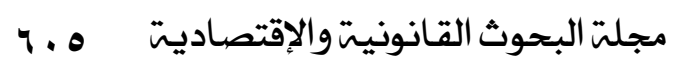


وبالإضافة إلى تعويض الضحية عن الأضرار المادية التى نتجت بصورة فورية

ومباثرة عن الجريمة، فإنه ينبغى أيضا أن تحصل على تعويض عن الأضرار المادية

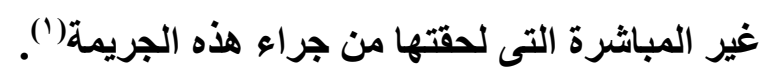

كما يتم تعويض الضحية عن الفرص الضائعة، بمـا فيها فرص العمل والتعليم

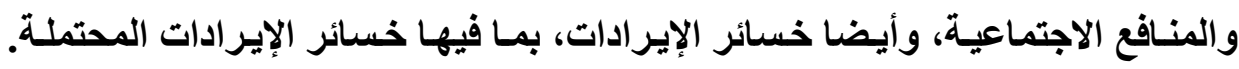

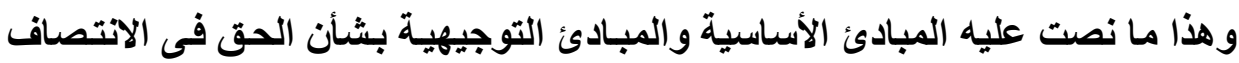

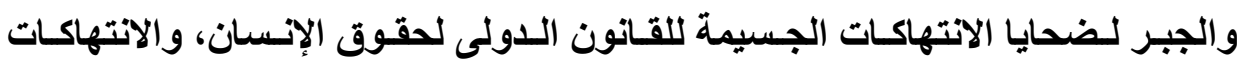

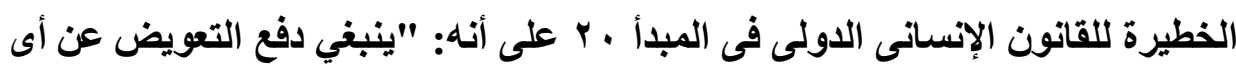

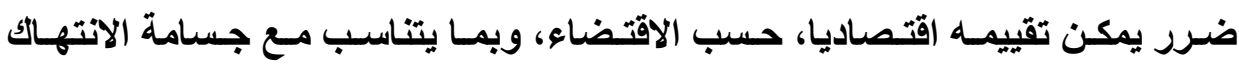
وظروف كل حالة، ويكون ناجما عن انتهاكات جسيمة للقانون الدولى لحقوق الإنسان، و الانتهاكات الخطيرة للقانون الإنسانى الدولى، من قبيل ما يلى:

$$
\text { (أ) الضرر البدنى أو العقلى؛ (- (الف) }
$$

(ب) الفرص الضائعة، بما فيها فرص العمل والتعليم والمنافع الاجتماعية؛

$$
\text { (ج) الأضرار المادية وخسائر الإيرادات، بما فيها خسائر الإيرادات المحتملة؛ }
$$

(د) ... (ه) التكاليف المترتبة على المساعدة القانونية أو مساعدة الخبراء والأدوية

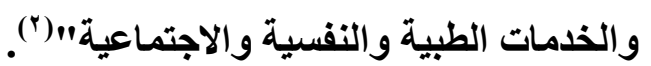

(1) Mohamed Mattar, Expert Consultation, Effective Remedies for Victims of Trafficking in Persons, Convened by the U.N. Special Rapporteur on trafficking in persons, especially women and children, Ms. Joy Ngozi Ezeilo, Bratislava, Slovakia, November 22-23, 2010, P. 17.

(2) Basic Principles and Guidelines on the Right to a Remedy and Reparation for Victims of Gross Violations of International Human=

$$
\text { مجلة البحوث القانونيت والإقتصاديت ج ـ }
$$


وباسـتقراء النـصوص القانونيـة السـابقة، نجــ أن إعـلان المبـادئ الأسـاسـية

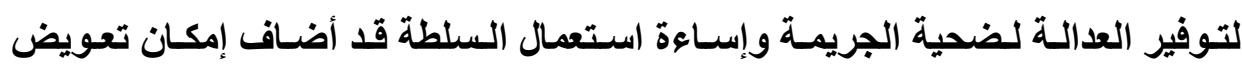
أسر الأثخاص المتوفين أو الذين أصبحوا عاجزين بذنيا، والذين يعتمدون فى إعالتهم

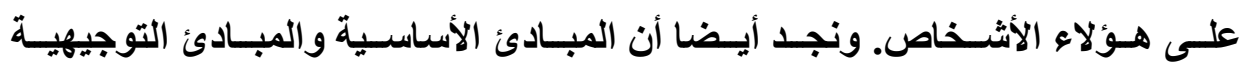
بثأن الحق فى الانتصاف والجبر لضحايا الانتهاكات الجسيمة للقـانون الدولى لحقوق الإنسـان قـ أضـافت التعويض عن الفـرص الـضائعة، وخسائر الإيـرادات المحتملـة،

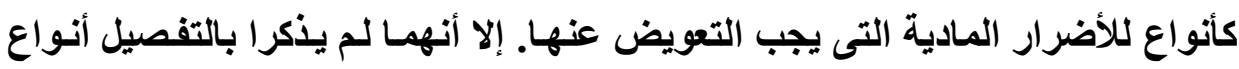
الأضرار الماديـة التى يمكن أن تصيب ضـية الاتجـار بالبشر، والتى يجب التعويض

فى حين نجد أن أكثر النصوص القانونيـة تفصيلا لأنواع الأضرار المادية التى تصيب الضحية هو نص القانون النموذجى لمكافحة الاتجار بالأثخاص.

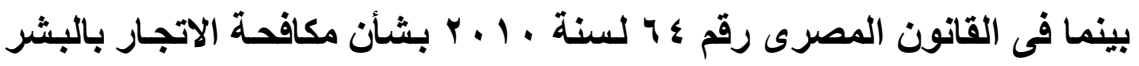
وإن كان قد نص فى الفقرة الثالثة من المادة الأولى منه على أن الضحية هو الشخص

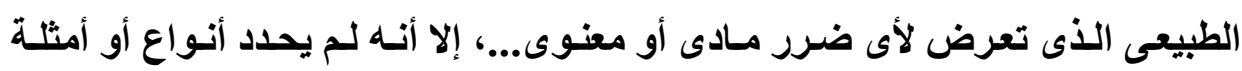
للأضرار المادية التى يجب تعويض ضحية الاتجار عنها.

$=$ Rights Law and Serious Violations of International Humanitarian Law, Adopted and proclaimed by General Assembly resolution 60/147 of December 16, 2005, UN Doc. A/RES/60/147 (2005). 


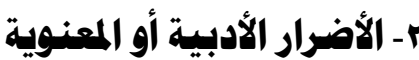

لا يقتصر تعويض ضحايا الاتجـار بالبشر على الأضرار المادية التى تصيبهم

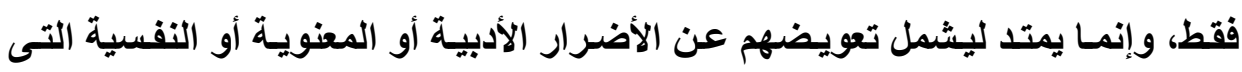
أصابتهم من جراء خضوعهم للاتجار بهم أو استغلالهم (').

وعلى ذلك، نصت المادة ^ ^ من القانون النموذجى لمكافحة الاتجار بالأشخاص

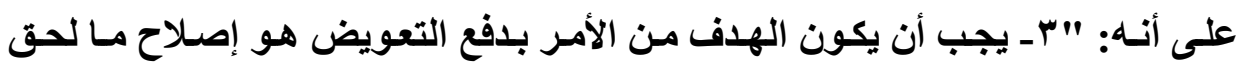
بالضحية من أذى أو خسارة أو ضرر بسبب مـا فعله الجـانى. ومـن الجـائز أن يشتمل فئل الأمر بالتعويض على دفع مبلِغ مقابل مـا يلـى: ... وـ دفع تعويض عن الأضرار غير المادية، المتأتية عن الأذى المعنوى أو البدنى أو النفسانى، والقهر العاطقى ومـا وقع

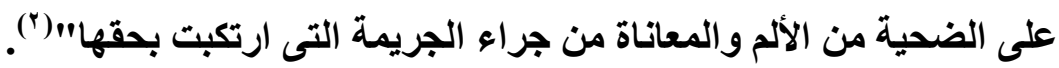
وقد عرف القانون المصرى رقم ء ؟ لسنة ـ 1 ـ ب بشأن مكافحة الاتجار بالبشر

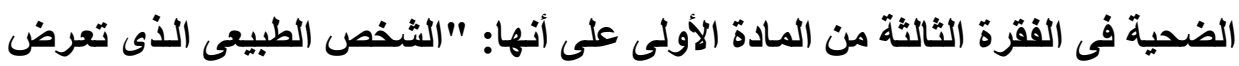

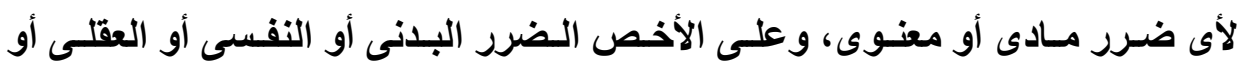

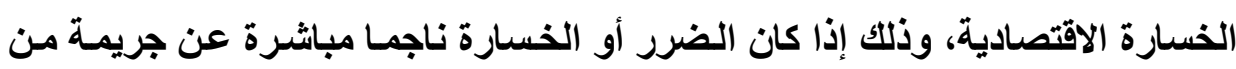
الجرائم المنصوص عليها في هذا القانون"(").

(1) Mohamed Y. Mattar, Incorporating the Five Basic Elements of a Model Antitrafficking in Persons Legislation in Domestic Laws: From the United Nations Protocol to the European Convention, Tulane J. of INT'L \& COMP. LAW, Vol 14:1, 2006, P. 36.

$$
\begin{aligned}
& \text { (ץ) قانون نموذجى لمكافحة الاتجار بالأثخاص، مكتب الأمم المتحدة المعنى بالمخدرات والجريمـة، }
\end{aligned}
$$

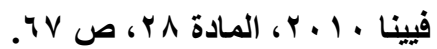

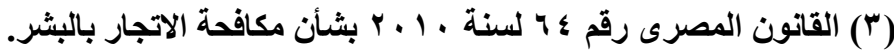

$$
\begin{aligned}
& \text { مجلت البحوث القانونيت والإقتصاديت ـ ـ }
\end{aligned}
$$


إذن، فالأضرار الأدبية أو المعنوية هى عبارة عن الأضرار أو الصدمة النفية الناجمة عن الاتجار بالبشر. ولكن ينبفى أن ندرك فى هذا الصدد أنه ليس كل ضرر نفسى ناتج عن الاتجار، وإنما غالبا ما يكون لـى ضـحايا الاتجـار بالبشر درجـة معينة من المشاكل النفسية السابقة على الاتجار بهم، نتيجة لظروف الفقر والمستوى المتلنى للمعيشة، أو وقوعهم ضـحايا لجريمـة اغتصـاب أو اعتـاءع جنسى، أو إسـاءة معاملـة

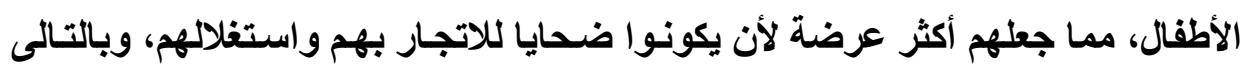
ليست كل المشاكل النفسية ناتجة عن الاتجار بهم.

ومن أمثلة الأضرار المعنوية، أن المرأة التى تم استغلالها فى ممارسـة البغـاء لا تستطيع مواجهة أسرتها أو مجتمعها، ولا تستطيع العيش بينهما، وإنما تكون مستبعدة ومستنكرة من المجتمع نتيجة لوصمة العار والسمعة السيئة التى لحقت بها.

كـلكف، تعيـق واقعـة الاتجـار والـصدمة النفسية المترتبـة عنهـا الـضحية عن ممارسة حياتها بشكل طبيعى، بل تؤثز بشكل سلبح ولمدى طويل على قدرتهم على

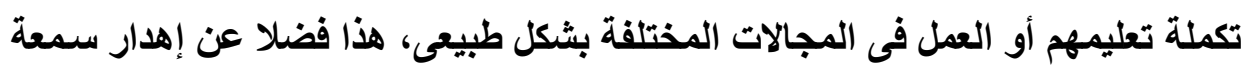

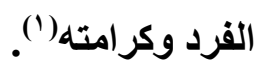

Teresa R. Castro and Roland M. وتطبيقا لذلك، حكم على الجنـاة Cuico كتعويض عن الأضرار المعنوية التى لحقت بضحايا جريمتهم، التى تتلخص وقائعها فى

(1) Comp. act, European Action for compensation for trafficked persons, Guidance on representing trafficked persons in compensation claims, A practical tool for lawyers, counselling centres and service providers, toolkit on compensation for trafficked persons, No Date, P. 5, 6 . 
أنهم قاموا باستغلال 9 فتيات قصر للقيام بأعمال جنسية منافية للآداب مع العملاء فى

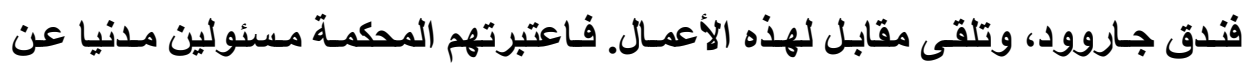

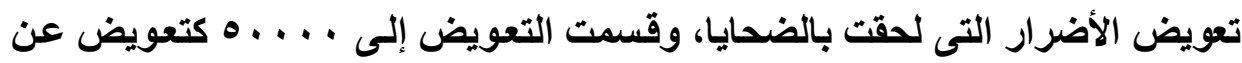

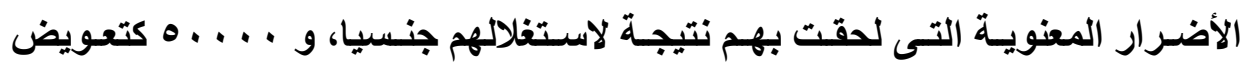
عقابى أو ردعى لعقابهم على عملهم غير المشروع، ولردع وتحذير غيرهم من ارتكاب لهني

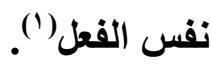

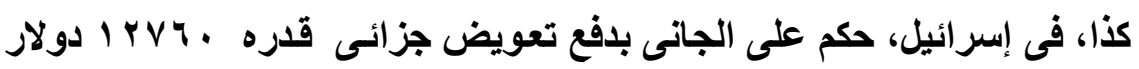

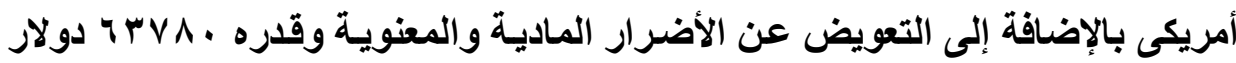

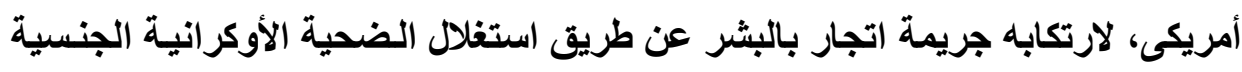

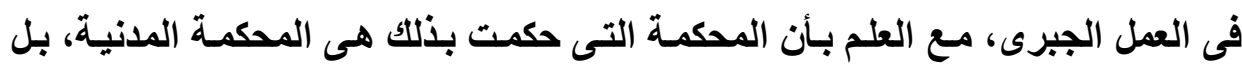
والأكثر من ذلك حكمت بالتعويض دون أن تثبت الضحية وقوع الأضرار التى لحقت بها،

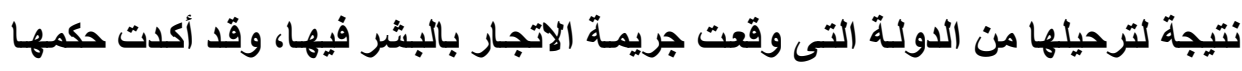
المحكمة العليا(").

(1) Philippines, Regional trial court, Branch 14, Criminal case No. CBU71993, Sentence date: 20-7-2007, UNODC No. PHL002,

(2) Israel, Supreme Court, Civil Appellate 3806/06, Sentence date: 26-52009, UNODC No. ISR005.

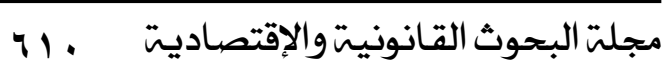




\section{المبحث الثالث}

\section{علاقة السببية بين الجريمة والضرر}

يشترط لإمكان المطالبة بالتعويض أن يكون الضرر ناتجا عن الجريمة، أى أن تكون الجريمة هى السبب فى حدوث هذا الضرر المطلوب التعويض عنه. ولذلك لكى

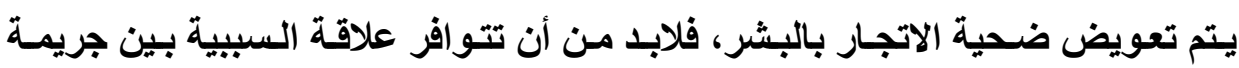

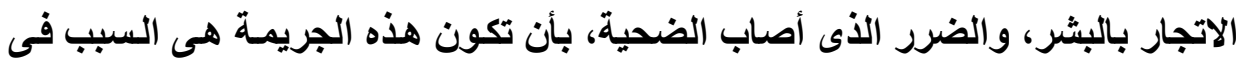

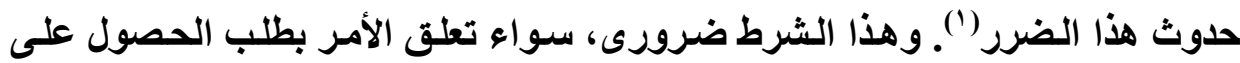
تعويض من الجانى، أو من الدولة.

وجدير بالذكر، أنـه لا يشترط أن تكون الجريمـة قد وقعت مباشرة على مـن أصابه ضرر منها، فقد تقع الجريمـة على شخص ويتعدى ضررها على آخر، فيكون

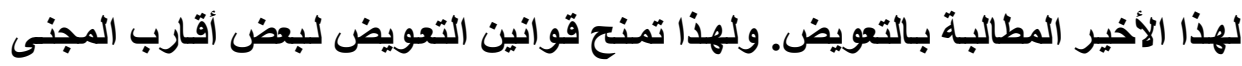
عليه حق المطالبة بالتعويض عن الأضرار التى أصابتهم من جراء الجريمة(؟). وعلاقة السبيية بين الضرر والجريمة حتى تكون متصلة، لابد أن لا يدخل بينها عامل أجنبى يقطعها، ويكون السبب فى إحداث الضرر، بحيث لا يكون للمتهم دخل في لإنى حدوثه. فالسبب الأجنبى هو حادث أو فعل لا ينسب إلى المتهم، ويترتب عليه أن يصبح

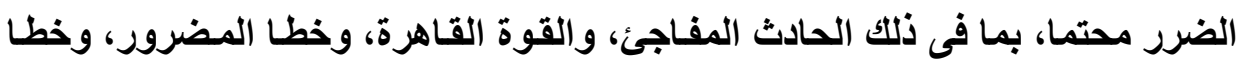


الغير. وعلى ذلك، إذا أثبت المـتهم أن الضرر حدث بسبب أجنبى، ولـم يكن لـه دخل بوقوعه، كان غير ملتزما بتعويض الضرر ('). 


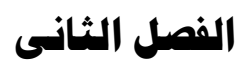 \\ تعويض ضحايا الاتجار بالبشر \\ وعقبات الصصول عليه بالطرق التقليدية}

\section{تمهيد وتقسيم: - n - n}

بعد توافر أركان المسئولية المدنية للجانى، من خطأوضرر وعلاقة السبيبة

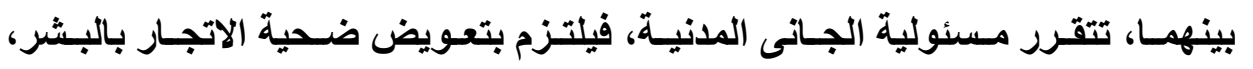
وغيرهم ممن تضرر من الجريمة، عن الأضرار المادية والأدبية التى لحقتهم من جراء

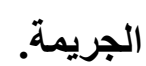

و هناك طرق تقليدية متعددة للحصول على التعويض، ولكن قد تصطدم بعقبات تحول دون الحصول عليه. وبناء على ذلك، نرى تقسيم هذا الفصل إلى ثلاثة مباحث، على النحو الآتى:

$$
\text { المبحث الأول: صاحب الحقى فى التعويض. }
$$

المبحث الثالث: الطرق التقليدية للحصول على التعويض والعقبات التى تواجهها. 


\section{المبحث الأول \\ صاحب الحق فى التعويض}

صاحب الحق فى التعويض هو المضرور من الجريمة، ولو لم يكن المجنى عليه

فيها. أما إذا لم يلحقه ضرر منها، فليس له الحق فى التعويض، ولو كان مجنيا عليه.

ويتمثل صاحب الحق فى التعويض فى ضحية الاتجـار بالبشر، وأسرته ومعاليه

الأين أصيبوا بضرر، وأيضا المتطوعين لمنع وقوع الجريمـة أو ضبط مرتكبها، ونبين ذلك بالتفصيل، على النحو الآتى:

أولا: الضمية

من البديهى أن الثخص الذى سيتم تعويضه هو ضحية جريمـة الاتجـار بالبشر،

باعتباره الشخص الذى وقع عليه الاعتداء وأصيب بالضرر، هذا بالطبع إن كان حيا.

وعلى ذلك، نصت الفقرة الثانية من المادة هب من اتفاقية الأمم المتحدة لمكافحة

الجريمة المنظمة عبر الوطنية على أنه: "تضع كل دولـة طرف قواعد إجرائية ملائمـة توفر لضحايا الجرائم المشمولة بهذه الاتفاقية سبل الحصول على التعويض وجبر

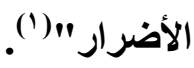

كما نصت الفقرة السادسة من المادة السادسة من بروتوكول منع وقمع ومعاقبة الاتجار بالأشخاص، وبخاصة النساء والأطفال، المكمل لاتفاقية الأمـ المتحدة لمكافحة الجريمة المنظمة عبر الوطنية على أنه: "تكفل كل دولة طرف احتواء نظامها القانونى

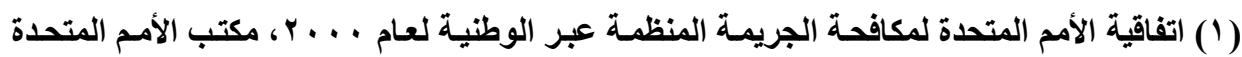

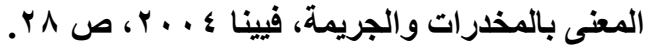

مجلت البحوث القانونيت والإقتصاديت 
الداخلى على تدابير تتيح لضحايا الاتجار بالأثخاص إمكانية الحصول على تعويض عن الأضرار التى تكون قد لحقت بهم"(').

\section{| - إتصود بالضمية:}

ويقصد بضحية الاتجار بالبشر، كما عرفها القانون النموذجى لمكافحة الاتجـار بالأشخاص، فى المادة ه فقرة أولى (ث) بأنه: "أى شخص طبيعى ممن كـان موضوع

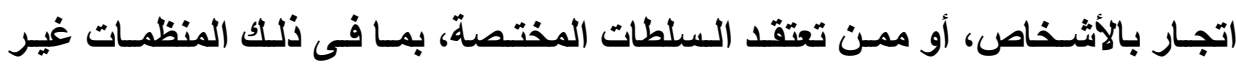
الحكومية المعنية، حيثما ينطبق ذلك، على نحو معقول بأنـه ضحية اتجـار بالأشخاص، بصرف النظر عمـا إذا كـان مرتكب الجرم قد عرفت هويتهـ أو قبض عليه أو حوكم أو بو

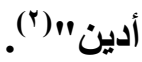

وهناك تعريفـا آخر للضحية أوسبع نطاقا، فى إعلان المبادئ الأساسية لتوفير العدالة لضحايا الجريمـة وإسـاءة استعمال السلطة: " ا ـ يقصد بمصطلح 》الضحايا《 الأشخاص الذين أصيبوا بضرر، فرديا أو جماعيا، بما فى ذلك الضرر البدنى أو العقلى أو المعانـاة النفسية أو الخسـارة الاقتـصادية، أو الحرمسان بلرجـة كبيـرة مـن التمتـع بحقوقهم الأساسية، عن طريق أفعال أو حالات إهمـال تشكل انتهاكـا للقوانين الجنائية الناقذة فى الدول الأعضاء، بما فيها القوانين التى تجرم التعف الإجرامى فى السلطة. Y - ويجوز اعتبار شخص ما ضحية، بصرف النظر عما إذا كان مرتكب الفعل قد عرف أو قبض عليه أو قوضى أو أدين، وبصرف النظر عن العلاقة الأسرية بينه وبين

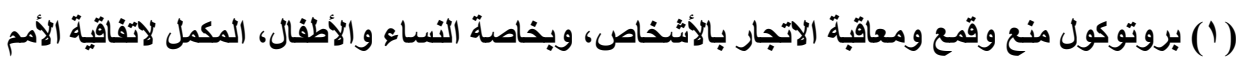

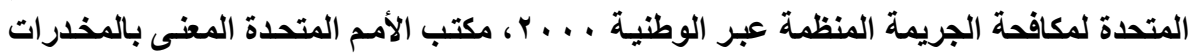

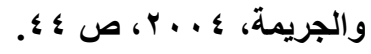
(ץ) قانون نموذجى لمكافحة الاتجار بالأشخاص، مكتب الأمم المتحدة المغنى بالمخدرات والجريمـة،

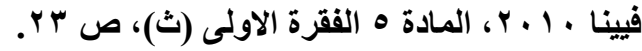

مجلت البحوث القانونيت والإقتصاديت 110 
الضحية..." ويشمل مصطلح 》الضحيةه أيضا، حسب الاقتضاء، العائلة المباشرة

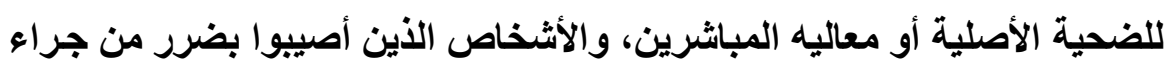
التخل لمساعدة الضحايا في محنتهم أو لمنع الإيذاء"('). وقد عرف الضحية أيضا القـانون العربى الاسترشـادى لـكافحة جرائم الاتجار

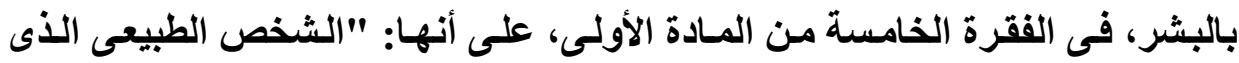

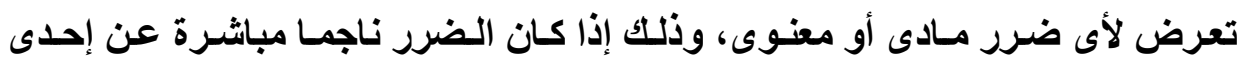
جرائم الاتجار بالبشر المنصوص عليها فى هذا القانون، بصرف النظر عما إذا كان النان

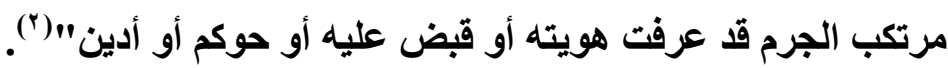

وقد عرف القانون المصرى رقم ع ؟ لسنة ـ 1 ـ ب بشأن مكافحة الاتجار بالبشر

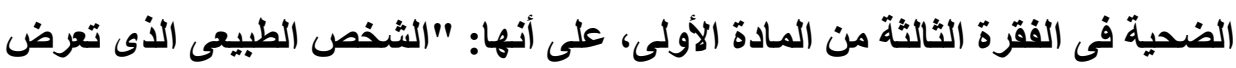

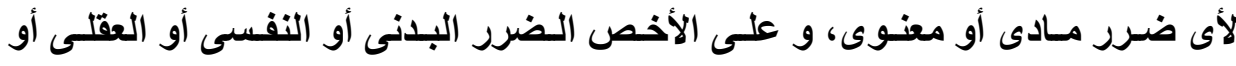

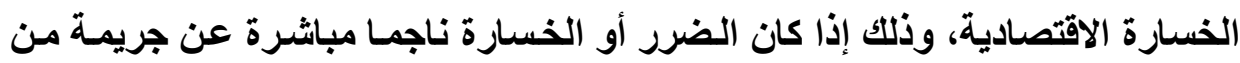
الجرائم المنصوص عليها فى هذا القانون"("). وتعليقا على هذه النصوص القانونية السابقة التى تعرف ضحية الاتجار بالبشر، نجد أن إعلان المبادئ الأساسية لتوفير العدالـة لضحايا الجريمسة وإسـاءة استعمال

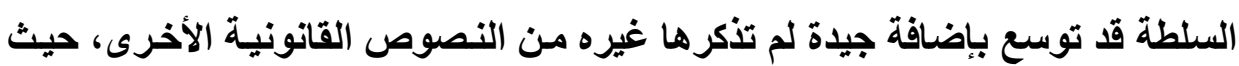

(1) Declaration of Basic Principles of Justice for Victims of Crime and Abuse of Power, Resolution adopted by the General Assembly, November 29, 1985, UN Doc. A/RES/40/34.

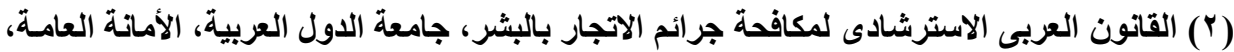

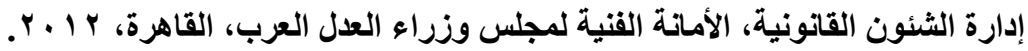

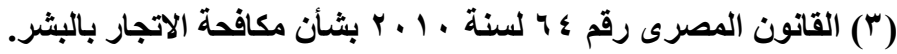

مجلة البحوث القانونيت والإقتصاديت ج الج 
توسـع فـى مفهـوم الـضحية ليسشمل العائلــة المباشـرة للـضحية الأصـلية أو معاليـه المباشرين، والأثخاص الذين أصيبوا بضرر من جراء التدخل لمساعدة الضحايا فى

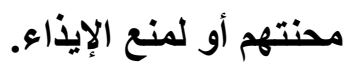

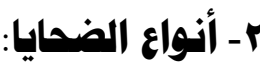

قد يكون الضحايا من الأطفـال، بمـا فى ذلك ضحايا الاستغلال الجنسى بهدف تحقيق منفعة مادية، أو ضحايا الاستغلال فى التسول، أو ترويج المخدرات، أو البغاء والمواد الإباحية، أو الاستغلال فى النزاعات المسلحة، أو الضحايا من فئة خدم المنازل، والذين يجبرون على القيام بأعمال تفوق احتمـالهم، وحرمـانهم من الأجر المتفق عليه فقى عقودهم.

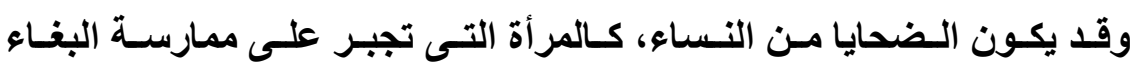
أو الأعمـال المنافيـة لـلآداب، والمـرأة التـى تجبـر على العمـل فـى الأمـاكن الخطرة، كالملاهى الليلية وغيرها. وأيا كاتت الضحية، فتنقسم إلى خمسة أنواع: اــ الـضحية الأصـلية: وهـو شـخص تعـرض لأذى مـا، سـواء جسـديا أو عقليـا أو اقتصاديا، بسبب تعرضـه لمجموعة من العوامل والأفعال ووسـائل وأغراض كمـا هـ مبينـة فى المـادة ب فقرة (أ) مـن البروتوكول المكمل لاتفاقية الأمـم المتحدة لمكافحة الجريمة المنظمة.

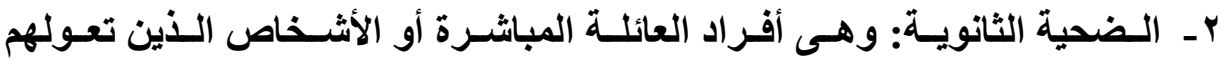
الـضحية، والأشـخاص الـذين عـانوا فـى مسـاعدة الـضحايا فـى شـدتهم أو لمنـع وقوعهم كضحايا. 
r- الضحية المستضعفة: هو شخص يعرف بأنه فى حالـة استضعاف أو ضيق غير عادية، إما بسبب السن، أو الحالة الجسمية أو العقلية، أو ممن لايه قابلية خاصـة

$$
\text { للوقوع فى فعل إجرامى (') }
$$

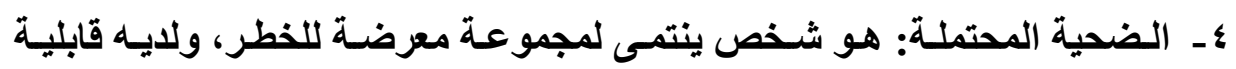
خاصة كى يكون عرضـه للاتجـار بـه، ويجب اتخـاذ إجراءات لمنع تحول الضحية

$$
\text { المحتملة إلى ضحية فعلية. }
$$

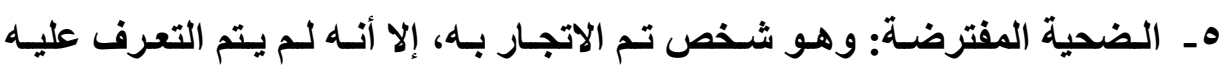

$$
\text { كضحية)(') }
$$

\section{ثانيا: أسرة الضحية وهماليه:}

من المعروف أن الجريمة تصيب بأضرارها أشخاصا آخرين غير المجنى عليه، وأكثر هؤلاء ضـررا هـم أقـارب المجنى عليـه الـذين كـان يعولهم المجنى عليـه قبـل

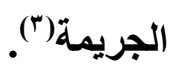

على ذلتك، لا يقتصر التعويض على الضحية الأصلية للاتجار بالبشر، وإنمـا

$$
\text { يثمل أيضا أسرته ومعاليه الذين أصييوا بضرر من جراء الجريمة(؛). }
$$

(1) Mohamed Y. Mattar, Incorporating the Five Basic Elements of a Model Antitrafficking in Persons Legislation in Domestic Laws: From the United Nations Protocol to the European Convention, previous reference, P. 28.

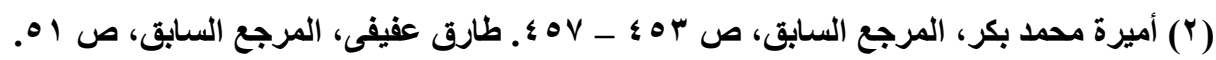

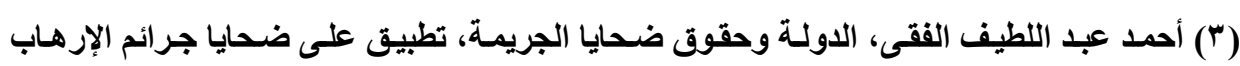

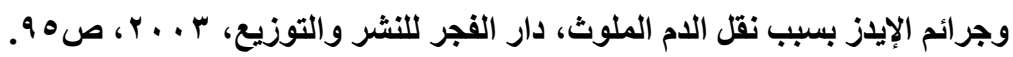

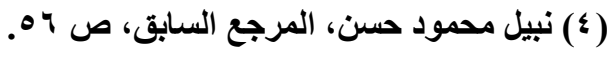


على ذلك، نص إعلان المبادئ الأساسية لتوفير العدالة لضحايا الجريمة وإساءة

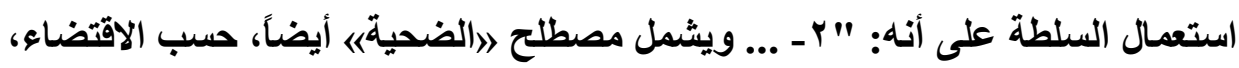

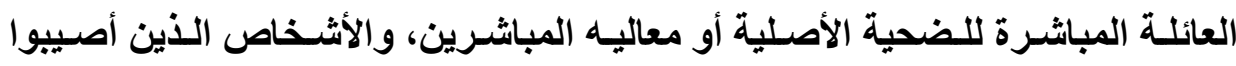
بضرر من جراء التخل لمساعدة الضحايا فح محنتهم أو لمنع الإيذاء". كنلك فى المادة 1 على أنه: "ينبغى أن يدفع المجرمون أو الغير المسئولون عن

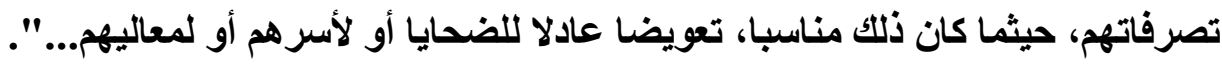
وفى المادة r 1 على أنه: "حيثـا لا يكون من المكن الحصول على تعويض

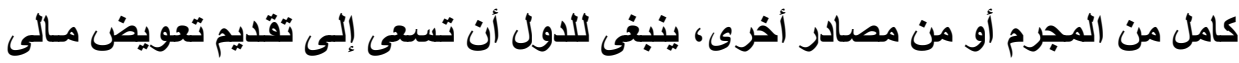
إلى

أــ الضحايا الذين أصيبوا بإصابات جسدية بالغة، أو باعتلال فى الصحة البننية أو

$$
\text { العقلية نتيجة لجرائم خطيرة. }
$$

بـ أسر الأشخاص المتوفين أو الذين أصبحوا عاجزين بننيا أو عقليا نتيجة للإيذاء،

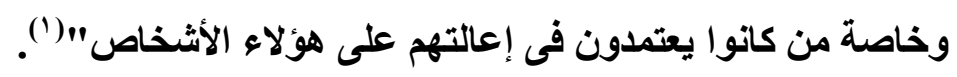

وقد عرف القانون النموذجى لمكافحة الاتجار بالأشخاص فى المـادة الخامسة

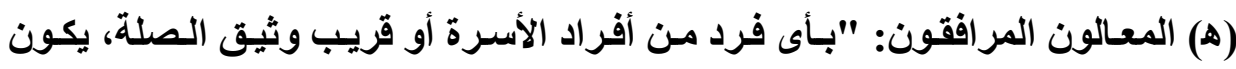

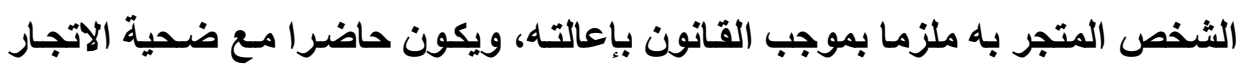

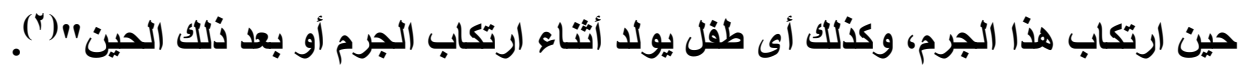

(1) Declaration of Basic Principles of Justice for Victims of Crime and Abuse of Power, Resolution adopted by the General Assembly, November 29, 1985, UN Doc. A/RES/40/34.

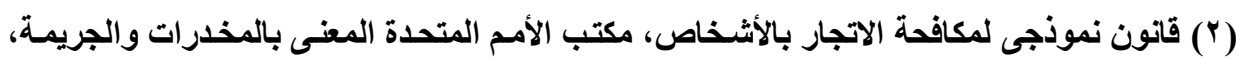

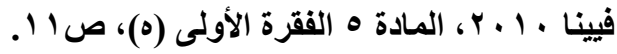

مجلت البحوث القانونيت والإقتصاديت 9 الب 119 
كذلك نص قانون إندونيسيا لمكافحة جريمة الاتجار بالأثخاص لعام V . . ب فى

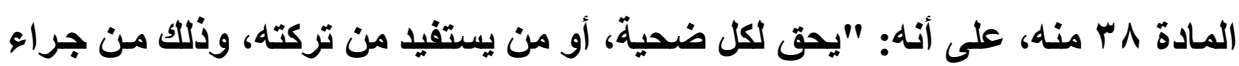
جريمـة الاتجـار بالبشر، الحصول على تعـويض لاسـترداد حقوقهم. والتعويض لـرد

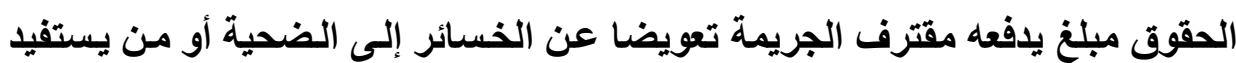

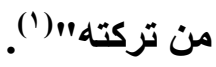

ولكن ينبغى أن نميز بين انتقال حق الضحية الأصلية فى التعويض إلى ورثنه، وبين حث أسرته أو معاليه فى التعويض عن الضرر الثخصى المباشر الذى لحقهم من الجريمة. فإن توفى المجنى عليه وله ورثة، فيكون لهم حق المطالبة بالتعويض المـادى

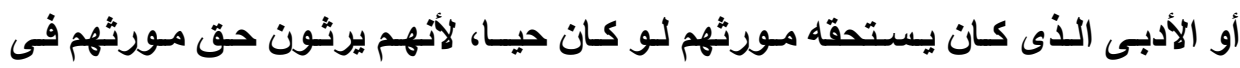

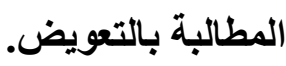

وينبغسى هنـا أن نميز بـين التعـويض مسن جـراء الـضرر المسادى، والتعـويض من جراء الضرر المعنوى. فالتعويض عن الضرر المـادى المتعلق بشـخص المجنى عليهِ يمكن تصور انتقالهِه إلى الورثة، الذين يخلفون المجنى عليه في دعوى وراثيـة

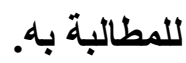

أمسـا التعويض عن الضرر الأدبى الذى ألم بشـخص المجنى عليه، وتعلق بـه ابتداء، والذى كان من المفروض أن يستحقه لو طالب به أثناء حياته، فلا يمكن انتقاله إلى ورثته، إلا إذا تحددت قيمته بمقتضى حكم قضائى، أو اتفـاق رضـائى. ويترتب على ذلك،، أنه إذا مات من له الحق فى التعويض عن الضرر الأدبى، قبل الاتفاق على مقدار التعويض، أو صدور حكم فيه يحدد مقداره، فالحق فى المطالبة به لا ينتقل إلى الورثة.

(1) Indonesia, Law on the Combat against the Crime of Trafficking in Persons, 2007.

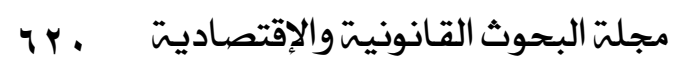


أما الأمر الأخر الذى نحن بصدده، فيحق لأسرة المجنى عليه ومعاليه المطالبة

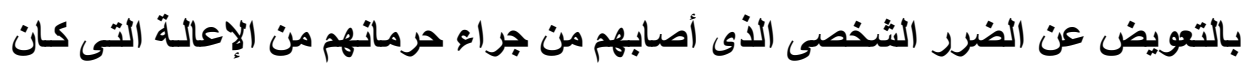

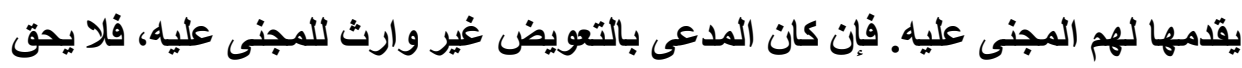

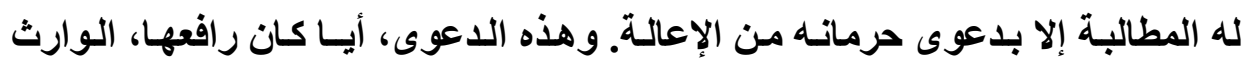

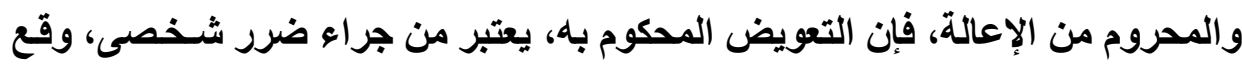

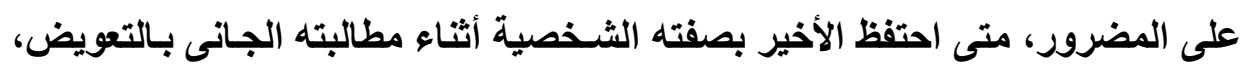

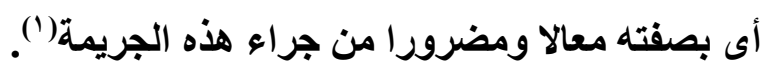

وباستقراء مـا سبق، نجد أن إعلان المبادئ الأساسية لتوفير العدالة لضحايا

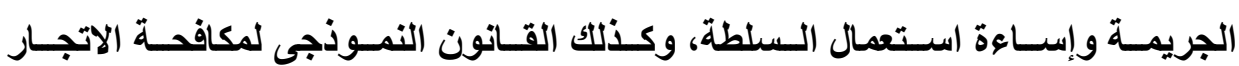
بالأشخاص، ورد بهما نص يعطى الأسرة والمعالين الحق فى التعويض، فى حين أنه لم

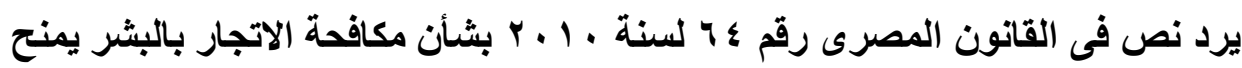

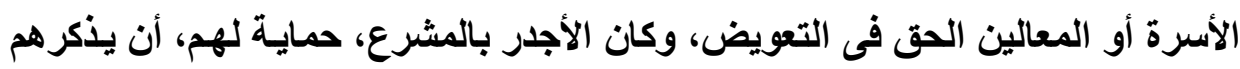
فى هذا القانون، دون أن يكتفى بالقو اعد العامة.

\section{ثالثا: المتطوع لمنع وقوع الجريية أو ضبط هرتكبها}

لقد نص إعلان المبادئ الأساسية لتوفير العدالـة لضحايا الجريمسة وإسـاءة

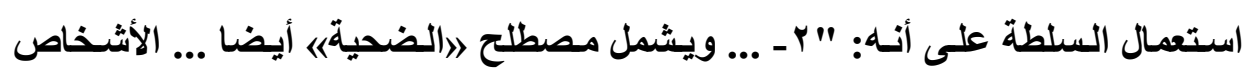

(1) أكرم فاضل، أسساس المسئولية المدنية عن الإصابات الجسدية وتحديد التعويض الناشنئ بسبيها،

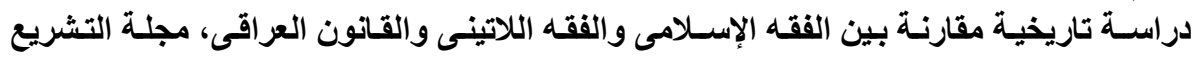

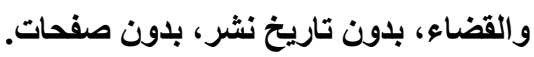

http://www.tqmag.net/body.asp? field=news arabic\&id=838, 5/3/2015.

مجلت البحوث القانونيت والإقتصاديت 
الـذين أصـيبوا بـضرر مسن جـراء التــلـل لمسـاعدة الـضحايا فـى محنـتهم أو لمنـع

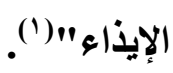

فمن المعلوم أن معظم القوانين تتيح للأفراد إمكانية التدخل لمنع وقوع الجرائم، سواء من خلال الحق فى الدفاع الشرعى، والأى يثبت للغير، كما يثبت للمعتدى عليه،

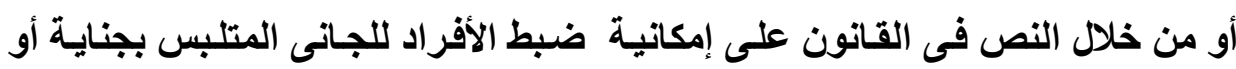
جنحة، يجوز فيها الحبس الاحتياطى، وتسليمه إلى أقرب رجل من رجال السلطة العامة،

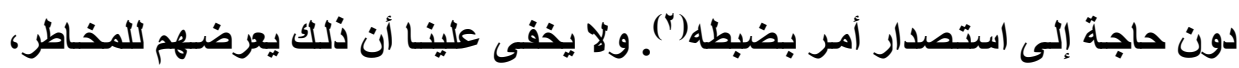
ولإصابتهم بالأضرار، نتيجة تلخلهم لمساعدة ضحايا الاتجـار، أو منـع وقوع الجريمـة، أو التخلص والهروب من الاتجار بهم أو استغلالهم. ومن أجل ذلك، وبغرض تشجيع

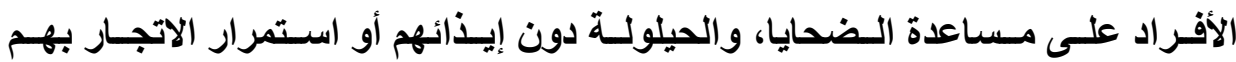
واستغلالهم، ولمساعدة العدالة فى ضبط المتجرين أو المستظلين، فيجب تعويضهم عن كافة الأضرار التى تصيبهم من جراء هذا التذخل("). وجدير بالأكر ، أن نص إعلان المبادئ الأساسية السابق يحسب له أنه توسع فى مفهوم الضحية، بحيث شمل هؤلاء، فى حين لم يـكرهم القـانون النمـوذجى أو القـانون المصرى بشأن مكافحة الاتجار بالبشر.

(1) Declaration of Basic Principles of Justice for Victims of Crime and Abuse of Power, Resolution adopted by the General Assembly, November 29, 1985, UN Doc. A/RES/40/34.

$$
\begin{aligned}
& \text { (Y) المادة V r من قانون الإجراءات الجنائية المصرى. }
\end{aligned}
$$

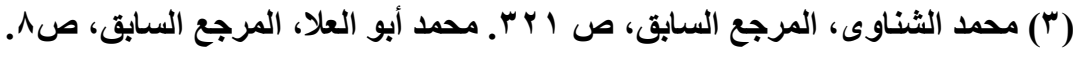

$$
\begin{aligned}
& \text { مجلت البحوث القانونيت والإقتصاديت }
\end{aligned}
$$




\section{المبحث الثانى \\ أنواع التهويض}

يتنوع التعويض الذى ينبغى أن تحصل عليه ضحية الاتجار بالبشر إلى تعويض لرد الحقوق والممتلكات وجبر الأضرار التى لحقته من جراء الاتجار بـه، وإلى تعويض

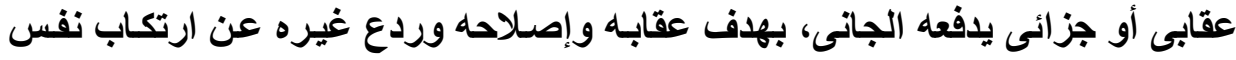

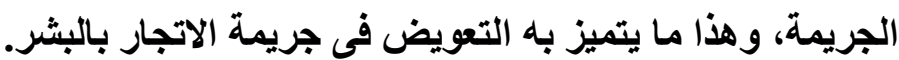

وأيضا قد يكون التعويض نقديا وهذا هو الأصل، وقد يكون عينيا فى صورة خدمات ومساعدات متنوعة تقدم إلى الضحية. ونعرض لهذه الأنواع المختلفة من التعويض بالتفصيل، على النحو الآتى:

\section{أولا: تعويض لرد الحقوق وجبر الأضرار}

إن تعويض ضحية الاتجار بالبشر برد الحقوق من أهم وسـائل الإنصاف التى ينبفى أن يحصل عليها الضحية، دون تطلب شروط معينة' (')

ويقصد برد الحقوق، أن يعيد الجانى إلى الضحية الحقوق التى انتههـا الفعل الإجرامى. وينصب رد الحقوق على الممتلكات أو الأموال التى تم الاستيلاء عليها نتيجة الهول السلوك الإجرامى الأى يحاكم عليه الجانى ()"

(1) Theodore R. Sangalis, Elusive empowerment: Compensating the sex trafficked persons under the trafficking victims protection act, Fordham Law Review, Vol. 80, 2011, P. 419. Also, NGO Committee to stop trafficking in persons, Recommendations on draft principles on the right to an effective remedy, 2012, P. 3.

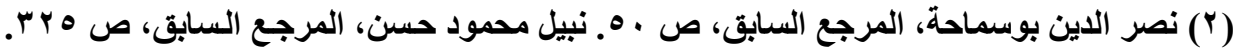

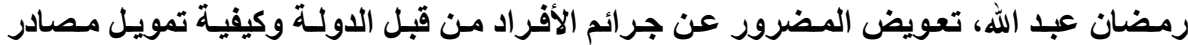

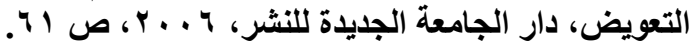

$$
\text { مجلتة البحوث القانونيت والإقتصاديت ب r }
$$


إذن فيتمثل هــا النـوع مـن التعـويض فـى حـى ضـحايا الاتجـار فـى الحصول

على تعويض لاسترداد حقوقهم، وجبر ما لحقهم من خسائر(') أو أضرار، ويهـف هذا

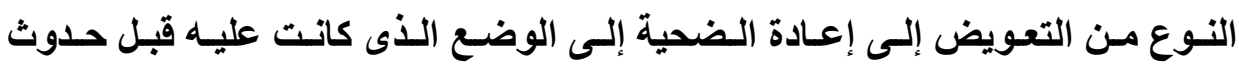

(الضرر) (ب).

وعلى ذلـك، نـص إعلان المبـادئ الأسـاسية لتوفير العدالـة لـضحية الجريمـة

وإساءة استعمال السلطة على أنه:" "ـ ينبغى أن يدفع المجرمون أو الغير المسئولون

عن تصرفاتهم، حيثما كان ذلك مناسبا، تعويضا عادلا للضحايا أو لأسرهم أو لمعاليهم.

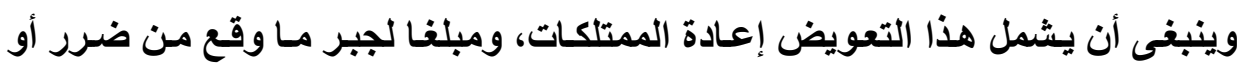

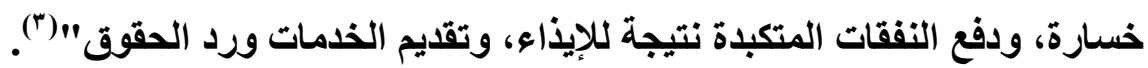

(1) مكتب الأمم المتحدة المغنس بالمخدرات والجريمـة والاتحساد البرلمسانى اللدولى، مكافحة الاتجـار

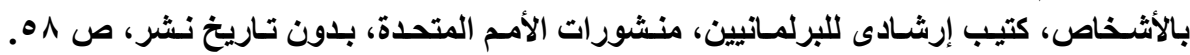

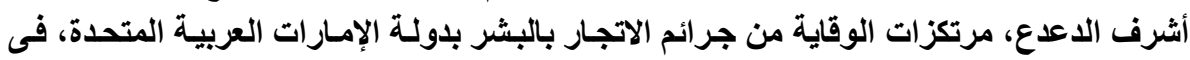

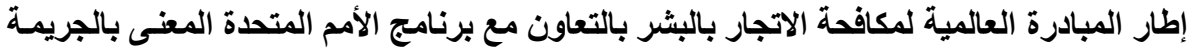

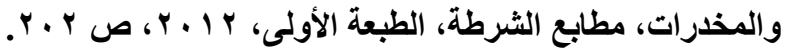

(2) Kathleen Kim, Civil litigation on behalf of victims of human trafficking,

The Legal Aid Foundation of Los Angeles, 2005, P. 53. Also, Anne T.

Gallagher, The right to an effective remedy for victims of trafficking in persons: A Survey of International Law and Policy, Paper submitted for the expert consultation convened by the UN Special Rapporteur on Trafficking in Persons, especially women and children, Ms. Joy Ngozi Ezeilo on: "The right to an effective remedy trafficked persons", Bratislava, Slovakia, 2010, P. 10.

(3) Declaration of Basic Principles of Justice for Victims of Crime and Abuse of Power, Resolution adopted by the General Assembly, November 29, 1985, UN Doc. A/RES/40/34. 
كذلك، نصت المـادة ^ r من القـانون النموذجى لمكافـة الاتجـار بالأشـخاص،

الصادر عن مكتب الأمم المتحدة المعنى بالمخدرات والجريمة، على أنـه: "بــ يجب أن يكون الهدف من الأمر بدفع التعويض هو إصلاح ما لحق بالضحية من أذى أو خسارة أو ضرر، بسبب ما فعله الجانى. ومن الجائز أن يشتمل الأمر بالتعويض على دفع مبلغ

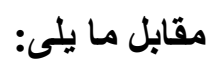

أ ـ تكاليف المعالجة الطبية أو الجسدية أو النفسية أو العقلية اللازمة للضحية.

بـ تكاليف العلاج الجسدى أو المهنى الطبى أو إعادة التأهيل اللازمة للضحية. ج- تكـاليف مـا يلزم للضحية من النقل والمواصـلات، أو رعايـة الأطفـال المؤقتـة، أو السكن المؤقت، أو نقل الضحية إلى مكان إقامة آمن مؤقت.

دـ فقدان الاخل والأجور المستحقة وفقا للقانون الوطنى واللوائح التنظيمية الخاصـة بالأجور.

هـ الرسوم القانونية وغيرها من التكاليف أو النفقات المتكبدة، بمـا فى ذلك التكاليف المتكبدة فيما يتعلق بمشاركة الضحية فى التحقيقات الجنائية وإجراءات المقاضاة. و ـ دفع تعويض عن الأضرار غير المادية، المتأتية عن الأذى المعنوى أو البدنى أو النفسى، والقهر العـاطفى ومـا وقع على الضحية مـن الألم والمعانـاة مسن جراء الجريمة التى ارتكبت بحقه. ز- أى تكاليف أو خسائر أخرى تكبلتها الضحية كنتيجة مباشرة لخضوعه للاتجار به،

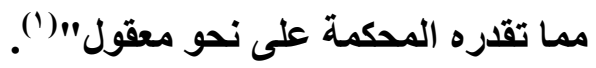
( (1) قانون نموذجى لمكافحة الاتجار بالأشخاص، مكتب الأمم المتحدة المعنى بالمخدرات والجريمـة،

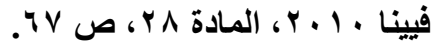


إذن، يشمل هذا النـوع مـن التعويض جبر كل الأضرار والخسائر التى لحقـت بالضحية من جراء الجريمـة، وتعويضها عن الفوائد والخدمات التى قدمتها للجـانى، وإعادة الأشياء إلى أصحابها الثرعيين(').

وعلى ذلـك، نـصت المبـادئ الأسـاسـية والمبـادئ التوجيهيـة بشـأن الحقى فـى الانتصاف والجبر لـضحايا الانتهاكسات الجسيمة للقـانون الــولى لحقـوق الإنسسان، والانتهاكات الخطيرة للقانون الإنسانى الدولى فى المـادة ه 1 والمتعلقة بجبر الضرر، على أن: "الغرض من الجبر الكـافى والفعـال والفورى هو تعزيز العدالة،، من خـلال معالجة الانتهاكـات الجسيمة للقـانون الدولى لحقوق الإنسان، أو الانتهاكـات الخطيرة

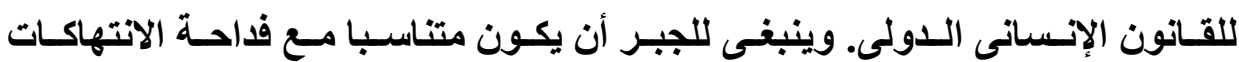
والأضرار المترتبة عليها. وتوفر الدولة، وفقـا لقوانينها المحلية والتزامـاتها القانونية

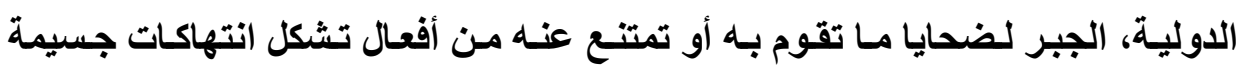
للقـانون الدولى لحقوق الإنسـان، وانتهاكـات خطيرة للقـانون الإنسانى الدولى. وفى الحالات التى يعتبر فيها شخص ما، أو شخصية اعتبارية،أو كيان آخر مطالبا بجبر أحد الدان الضحايا، ينبغي أن يوفر الطرف المسئول عن الانتهاك جبرا للضحية، أو للاولة إذا لـا كانت الدولة قد وفرت فعلا الجبر للضحية" لئية وبالإضافة إلى ذلك، نصت فى المادة 9 أعلى أن: "الرد ينبغى، متى أمكن ذلك،

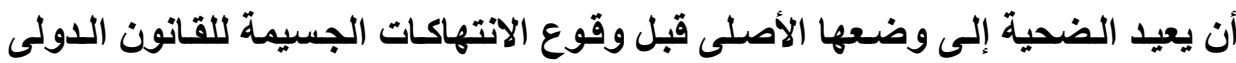
لحقوق الإنسان أو الانتهاكات الخطيرة للقانون الإنسانى الدولى. ويتضمن الرد، حسب

(1) Mohamed Mattar, Expert Consultation, Effective Remedies for Victims of Trafficking in Persons, Convened by the U.N. Special Rapporteur on trafficking in persons, especially women and children, previous reference, $P .14$. 
الاقتضاء، ما يلى: استرداد الدرية، والتمتع بحقوق الإنسان، واسترداد الهوية، والحياة الأسـرية والمواطنـة، وعـودة المـرء إلـى مكــان إقامتــه، واسـترداد الوظيفـة، وإعـادة

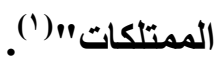

وتنص الفقرة الأولى من المادة ه V من نظام رومـا الأساسـى للمحكمة الجنائية

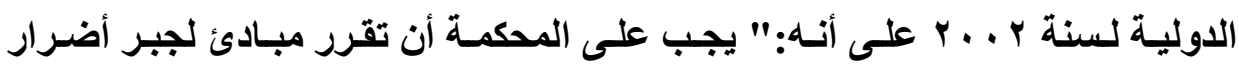

الضحايا، بما يشمل رد الحقوق والتعويض وإعادة التأهيل. وعلى هذا الأسـاس، يمكن للمحكمة فى حكمها، سواء بناء على طلب أو بمبادرة منها فى الظروف الاستثنائية، أن تحدد نطاق ومدى أى ضرر أو خسارة أو إصابة لحقت بالضحية"(r).

وتعتبر مسألة رد الحقوق الإجراء الوحيد الذى أقر بـه من بين إجراءات جبر

أضرار الضحايا أمام المحاكم الجنائية الدولية الخاصة. ويظهر ذلك جليا من خلال نص رله

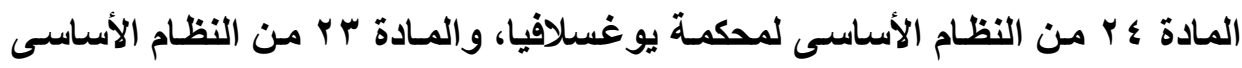
لمحكمة رواندا، والمادة 9 أمن النظام الأساسـى لمحكمة سيراليون، حيث نصت على إمكانية قيام المحكمة بإصدار أوامر بمصادرة أية ممتلكات أو عوائد تم الاستيلاء عليها بسلوك إجرامى، وأن تأمر بإعادتها إلى المالكين الشرعيين(").

(1) Basic Principles and Guidelines on the Right to a Remedy and Reparation for Victims of Gross Violations of International Human Rights Law and Serious Violations of International Humanitarian Law, Adopted and proclaimed by General Assembly resolution 60/147 of December 16, 2005, UN Doc. A/RES/60/147 (2005).

(2) Article 75 (1) (Reparations to Victims) of the Rome Statute of the International Criminal Court (2002).

$$
\text { ("آ) نصر الدين بوسماحة، المرجع السابق، ص ـ. }
$$$$
\text { Trv مجلة البحوث القانونيت والإقتصاديت }
$$ 
وفيما يتعلق بالقوانين الوطنية، فبموجب قانون الولايات المتحدة الأمريكية فى البند ب9ه 10 من الباب 1 1 فيما يتعلق برد الحقوق التعويضى الإلزامى، يلتزم الجـانى بدفع التعويض الأى يجبر كامل مقدار الخسائر والأضرار التى لحقت بالضحية، والتى

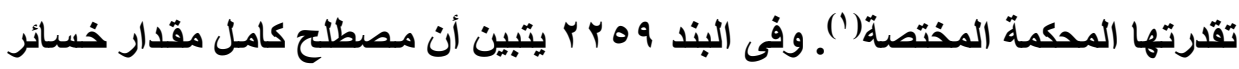
الضحية تشمل جميع النفقـات التى تكبدتها الضحية مقابـل الخدمات الطبيـة المتعلقة بالرعاية الجسدية أو العقلية أو النفسية، والعلاج الجسدى أو المهنى، أو إعادة التأهيل

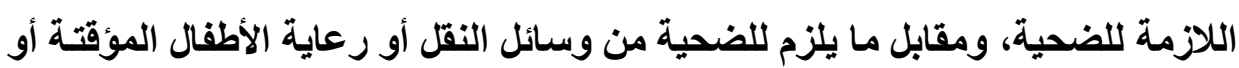
السكن المؤقت، ومقابل فقدان الاخل، وأتعاب المحاماة والتكاليف الأخرى، وأيضا مقابل أى خسائر أخرى تكبدتها الضحية كنتيجة مباشرة لخضوعله للاتجار به(؟).

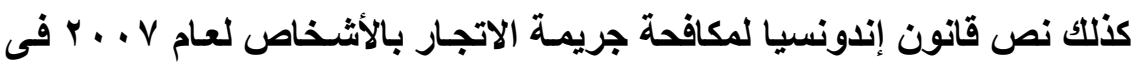

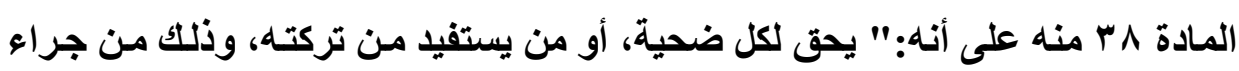

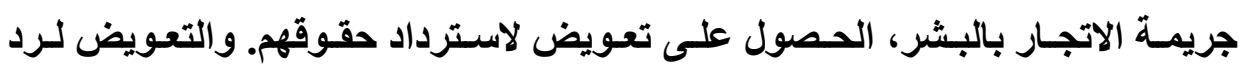
الحقوق مبلغ يدفعه مقترف الجريمة تعويضا عن الخسائر إلى الضحية أو من يستفيد من تركته "("ام).

(1) United States Code, Section 1593 of Title 18:Mandatory restitution: (1) The order of restitution under this section shall direct the defendant to pay the victim (through the appropriate court mechanism) the full amount of the victim's losses, as determined by the court under paragraph (3) of this subsection.

(2) United States Code, Section 2259 of title 18. Also, Alabama code 13A-6155 (2011).Arizona, REV. STAT. ANN. § 13-1309 (2011).

(3) Indonesia, Law on the Combat against the Crime of Trafficking in Persons, 2007. 
وباستقراء النصوص التى وردت فى الاتفاقيات الدولية والقوانين الوطنية، نجد أن القانون النموذجى لمكافحة الاتجار بالبشر، والقانون الأمريكى قد نصا بالتفصيل عن الحقوق التـى تـرد كتعـويض للـــية، كنفقـات العـلاج والسكن وتكـاليف النقل والمواصـلات والرسـوم القانونيـة، وغيرهـا. فـى حين ورد النص على التعويض لرد الحقوق، دون أن يقوم بتعدادها كلا من إعلان المبادئ الأساسية لتوفير العدالة لضحية

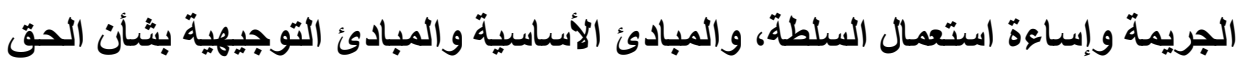
فى الانتصاف والجبر لضحايا الانتهاكـات الجسيمة للقانون الدولى لحقوق الإنسان والانتهاكـات الخطيرة للقانون الإنسانى الدولى، إلا أن هذا الأخير قد أضساف استرداد

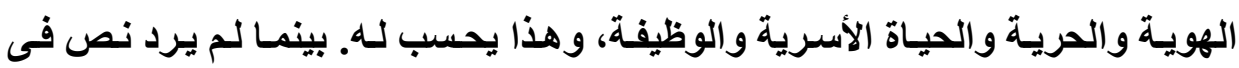

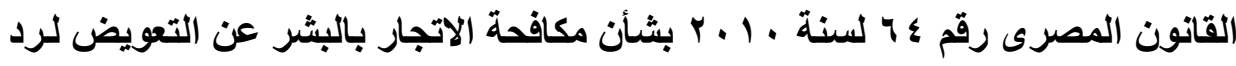
الحقوق والممتلكات، وكان الأجدر بالمشرع أن ينص على ذلك أسوة بالاتفاقيات الدولية والقوانين الوطنية الأخرى.

وتطبيقـا لذلك، حكم على خوزيـه الذى كـان يتـاجر بالأيدى العاملـة فى أمريكا

الثمالية، الذى كان يستعبد المواطنين المغرر بهم من أمريكا اللاتينية كعمال مزارع، وقد سبق أن أقر بالتآمر وإيواء رعايا أجانب ليس لايهم وثائق شخصية، كسبا للمـال، وحيازة وثائق شخصية مزورة، وأفعال إجرامية أخرى متأتية عن دوره فى حلقة اتجـار

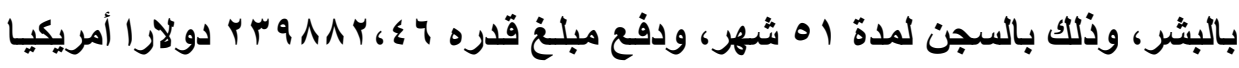

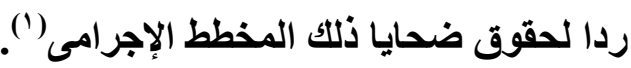

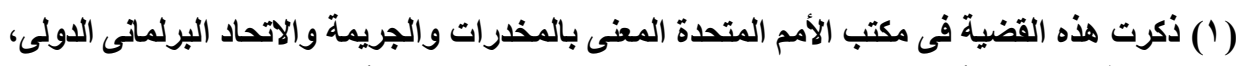

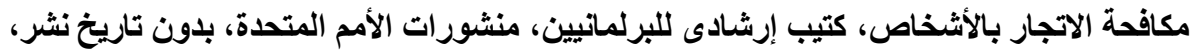




\section{ثانيا: التعويض الجزائى أو العقابى:}

لا يقتصر تعويض الضحايا، فى بعض النظم القانونيـة، على تعويضهم عن

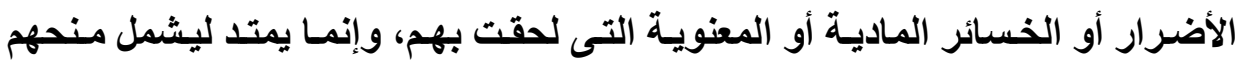

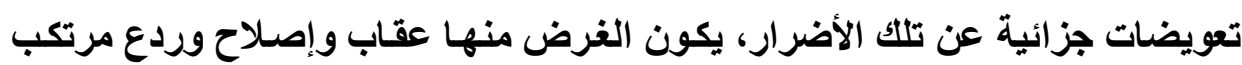
الجريمة، الأى نتج عن فعله غير المشروع الإضرار بالضحية'(')

إذن، فهـذه التعويضات تمـنح بالإضـافة إلسى التعويض عـن الأضـرار الفعليـة

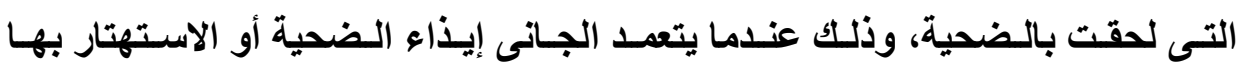

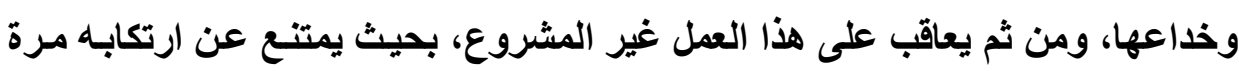

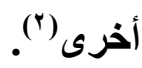

ومن النظم القانونية النى تمنح الضحايا تعويضات جزائية عن الأضرار، قانون

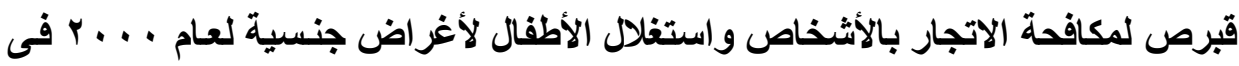

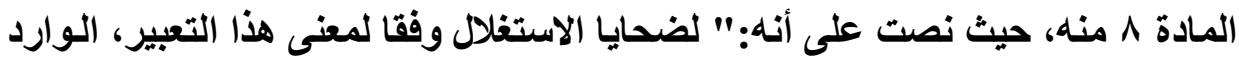
فى هذا القانون، حق إضـافى فى تلقى تعويضات عن الأضرار تجاه أى شخص يكون الهن مسئولا عن استغلالهم، ومن ثم عليه تحمل تبعة التعويض عن الأضرار، الخاصة منها فيأ

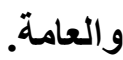

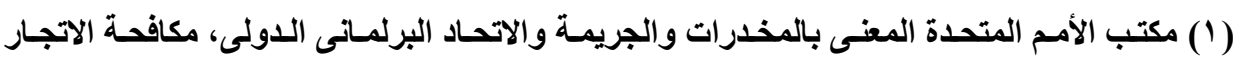

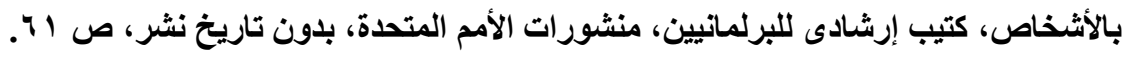

(2) Mohamed Mattar, Expert Consultation, Effective Remedies for Victims of Trafficking in Persons, Convened by the U.N. Special Rapporteur on trafficking in persons, especially women and children, previous reference, $P .13$. 
ويجب أن تكون التعويضات العامـة عن الأضـرار المشار إليهـا أعلاه منصفة ومعقولة، ويجوز للمحكمة، عند تقديرها تلك التعويضات، أن تأخذ فى الاعتبار ما يلى: أ ـ مـدى الاسـتفلال الواقع، والنفع الذّى اسـتمده الشخص الذّى تقع عليـه تبعـة التعويض من ذلك الاستغلال. بـ التوقعات المستقبلية لاى الضحية، ومدى تأثر تلك التوقعات بالاستغلال الذى وقع عليه.

$$
\text { ج- مقدار الذنب الواقع على عاتق مرتكب الجرم. }
$$

دـ علاقـة مرتكب الجـرم بالـضحية، أو مالـهـ مـن وضـعية سـيطرة أو تـأثير على الضحية.

ويجوز للمحكمة أن تمنح الموافقة على التعويضات الجزائية عن الأضرار عندما تقتضى ذلك درجة الاستغلال، أو درجة العلاقة بين مرتكب الجرم والضحية، أو وضعية مرتكب الجرم من حيث السيطرة أو التأثير على الضحية. وتأخذ المحكمة فى الاعتبار، للى منح الموافقة على التعويضات الخاصـة عن الأضرار، كل بند من بنود النفقات التى نتجت عن الاستغلال، بما فى ذلك تكاليف الإعادة

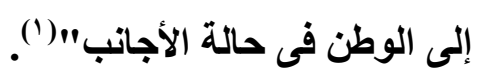

كذلك، نص البند V • ا من قانون الولايات المتحدة لإعادة التكليف بالصلاحيات

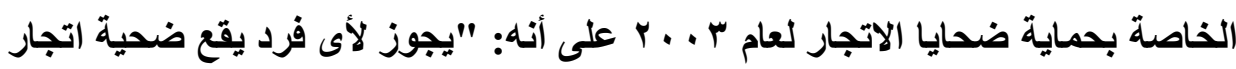
بالأشخاص أن يرفع دعوى مدنية على مقترف هذا الجرم إلى محكمة محلية مختصة فى

(1) Cyprus, Law on Combating of Trafficking in Persons and Sexual Exploitation of Children, 2000.

مجلت البحوث القانونيتو الإقتصاديت اسبT 
الولايات المتحدة، ويجوز له أن يحصل على تعويض عمـا لحق بـه من أضرار، وكذلك على مبلغ معقول لافع أتعاب المحامى" (')

ولم يأخذ القانون المصرى رقم ء ؟ لسنة ـ 1 ـ ب بشأن مكافحة الاتجار بالبشر بفكرة التعويض العقابى، ونرى أنه كان الأجلر بالمشرع المصرى أن ينص عليه، نظرا للخطورة والجسامة التى تتميز بها جرائم الاتجـار بالبشر، والتى تحتـاج إلى فرض تعويضات عقابية، يكون الهوف منها ردع مرتكب هذه الجريمة.

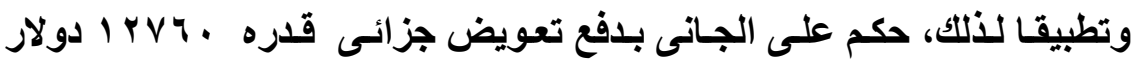

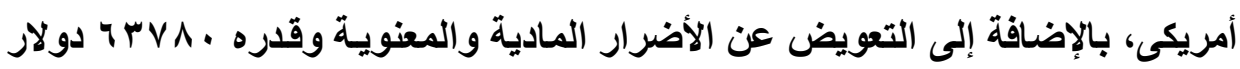
أمريكى، لارتكابه جريمة اتجار بالبشر، عن طريق استغلال الضحية الأوكرانية الجنسية فى العمل الجبرى، مـع العلم بـأن المحكمة التى حكمت بـللك هـى المحكمة المدنيـة، بـل والأكثر من ذلتك، حكمت بالتعويض دون أن تثبت الضحية وقوع الأضرار التى لحقت بها نتيجة لترحيلها من الدولة التى وقعت جريمـة الاتجـار بالبشر فيها، وقد أكدت حكمها

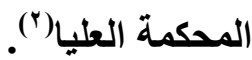

كنلك، حكم على الجناة Teresa R. Castro and Roland M. Cuico القلبينيبين الجنسية بـدفع تعويض قدره وقائعها فى أنهم قاموا باستغلال و فتيات قصر للقيام بأعمال جنسية منافيـة للآداب مـع العملاء فى فندق جـاروود، وتلقى مقابل لهذه الأعمـال. فـاعتبرتهم المحكمة مسئولين مـنيا عن تعويض الأضرار التى لحقت بالـحايا، وقسمت التعويض إلى . . . .

(1) United States Trafficking Victims Protection Reauthorization Act of 2003, Section 107.

(2) Israel, Supreme Court, Civil Appellate 3806/06, Sentence date: 26-52009, UNODC No. ISR005. 
كتعويض عن الأضرار المعنوية التى لحقت بهم نتيجة لاستغلالهم جنسيا، و . . . . . كتعويض عقابى أو ردعى لعقابهم على عملهم غير المشروع، ولردع وتحذير غيرهم

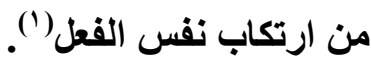

\section{ثالثا: التعويض النقدى}

الأصل هو أن يكون التعويض نقديا، أى بدفع مبلغ من النقود، تحكم به المحكمة على المسئول، لجبر الأضرار التى أصابت المضرور. فوظيفة النقود جبر الضرر النـاتج

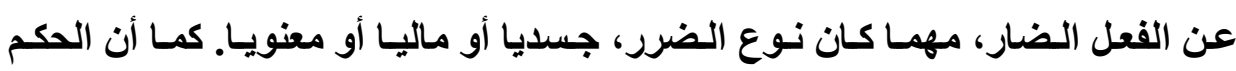

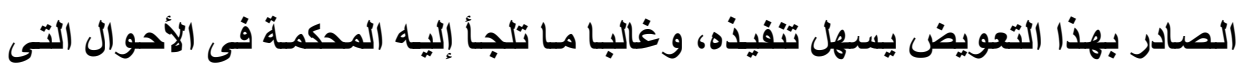

$$
\text { يتعذر فيها التعويض العينى (؟). }
$$

وعلى ذلـك، نـص إعـلان المبـادئ الأسـاسية لتـوفير العدالـة لـضحية الجريمـة وإساءة استعمال السلطة على أنه: "^-ـ ينبغى أن يدفع المجرمون أو الغير المسئولون

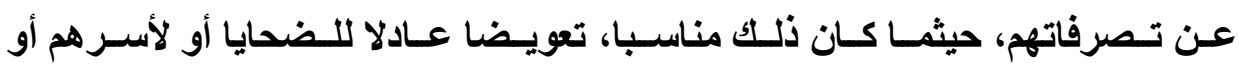
لمعـاليهم. وينبغس أن يـشمل هـذا التعويض إعـادة الممتلكـات، ومبلغـا لجبر مساوقع

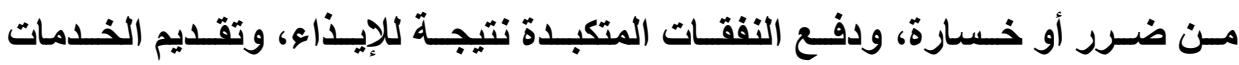

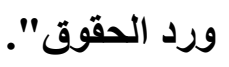

كمـا نص على أنـه: "ب ا ـ حيثمـا لا يكون من الممكن الحصول على تعويض كامل من المجرم أو من مصادر أخرى، ينبخى للاول أن تسعى إلى تقديم تعويض مسالى

(1) Philippines, Regional trial court, Branch 14, Criminal case No. CBU71993, Sentence date: 20-7-2007, UNODC No. PHL002,

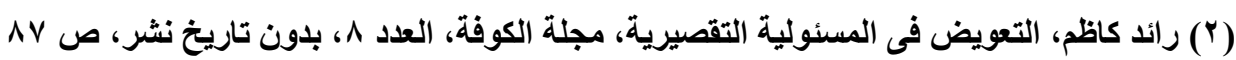
و مجلتّ البحوث القانونيت والإقتصاديت ب Tr 
إلىى: أـ الضحايا الذين أصييوا بإصـابات جسدية بالغة أو بـاعتلال الصحة البلنيـة أو العقلية نتيجة لجرائم خطيرة.." (').

كما يمكن أن يكون التعويض النقدى أو المالى فى صورة دفع أتعاب المحامى أو

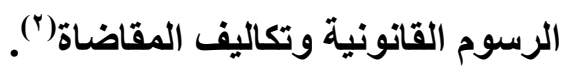

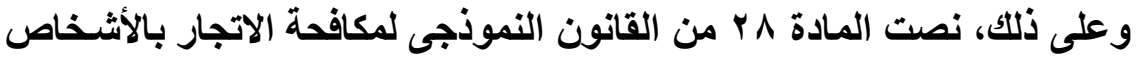

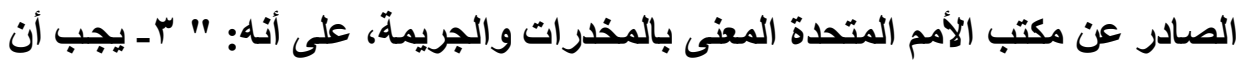
يكون الهاف من الأمر بدفع التعويض هو إصلاح ما لحق بالضحية من أذى أو خسارة

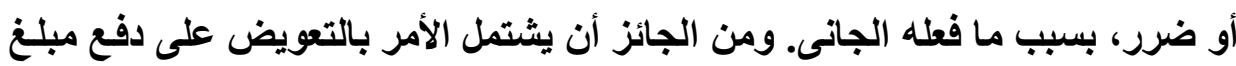

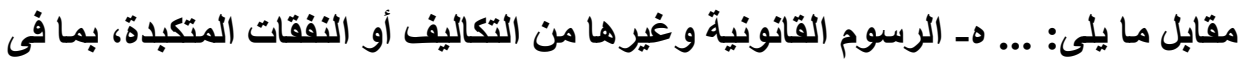
ذللك، التكاليف المتكبدة فيما يتطلق بمشاركة الضحية في التحقيقات الجنائية وإجراءات التهات

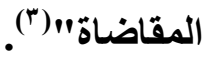

كنلك، نص البند V • 1 من قانون الولايات المتحدة لإعادة التكليف بالصلاحيات

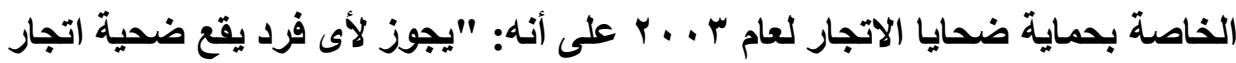

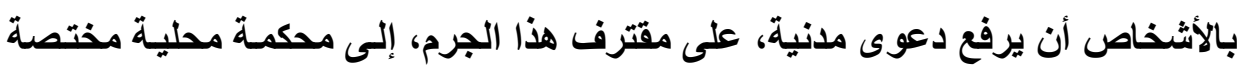

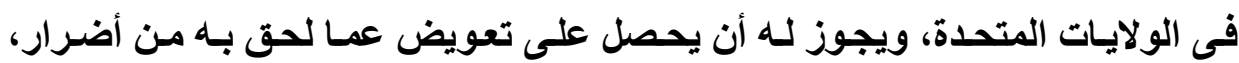
وكذلك على مبلغ معقول لافع أتعاب المحامى" (")

(1) Declaration of Basic Principles of Justice for Victims of Crime and Abuse of Power, Resolution adopted by the General Assembly, November 29, 1985, UN Doc. A/RES/40/34.

(2) Kathleen Kim, previous reference, P. 54.

(ए) قانون نموذجى لمكافحة الاتجار بالأثخاص، مكتب الأمم المتحدة المعنى بالمخدرات والجريمـة،

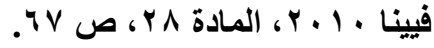

(4) United States Trafficking Victims Protection Reauthorization Act of 2003, Section 107.

$$
\text { مجلة البحوث القانونيت والإقتصاديت ع با }
$$


وقد يتمثل جزء من التعويض النقدى فى مبلـغ من المـال مقابل النفقات التـى

نتجت عن الاستغلال، بما فى ذلك تكاليف الإعادة إلى الوطن في حالة الأجانب(')، أو الو يتمثل فى مبلغ مقابل تكاليف ما يلزم للضحية من النقل و المواصلات، أو الو رعاية الأطفال

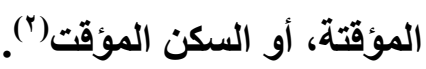

\section{رابعا: التعويض العينى (غير النقدى)}

إذا كان الأصل أن يكون التعويض نقديا، إلا أنسه أحيانـا قد يكون غير نقدى أو

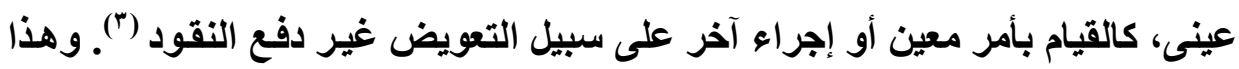

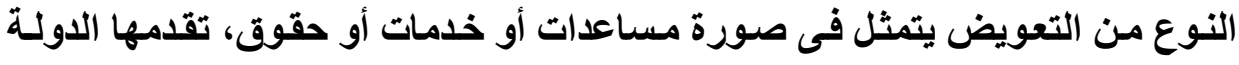
للضحايا، كتوفير السكن اللائق، وتقديم المعلومسات و المشـورة الخاصـة بحقوقههم،

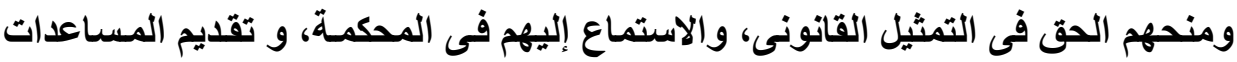

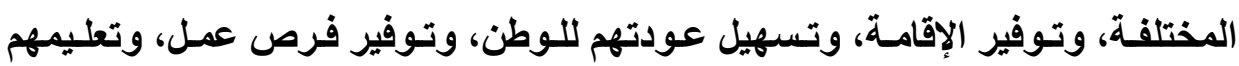

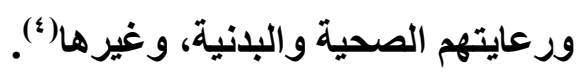

(1) Cyprus, Law on Combating of Trafficking in Persons and Sexual Exploitation of Children, 2000.

(ץ) قانون نموذجى لمكافحة الاتجار بالأثخاص، مكتب الأمم المتحدة المعنى بالمخدرات والجريمـة،

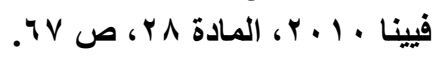

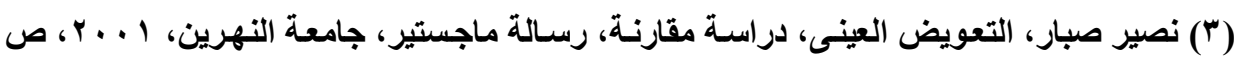

(4) Margaret Malloch, Tara Warden and Niall Hamilton, Care and Support for Adult Victims of Trafficking in Human Beings, Scottish Centre for Crime and Justice Research, 2012, P. 18. 


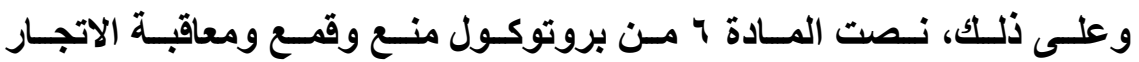
بالأثخاص، وبخاصة النساء والأطفال، المكمل لاتفاقية الأمم المتحدة لمكافحة الجريمة المنظمة عبر الوطنية على أنه:

" ا ـ تحرص كل دولة طرف، فى الحسالات التى تقتضى ذلكت وبقدر مـا يتيحه قانونها

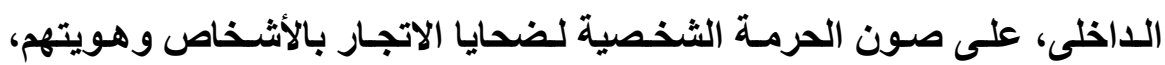
بوسائل منها جعل الإجراءات القانونية المتعقة بذلك الاتجار سرية. r ـ تكفل كل دولة طرف احتواء نظامها القانونى أو الإدارى الداخلى على تدابير توفر لضحايا الاتجار بالأشخاص، فى الحالات التى تقتضى ذلك، ما يلى: أ ـ معلومات عن الإجراءات القضائية والإدارية ذات الصلة. بـ مساعدات لتمكينهم من عرض آرائهم وشواغلهم وأخذها بعين الاعتبار فى الحى

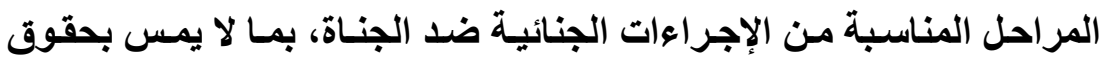

$$
\text { الدفاع. }
$$

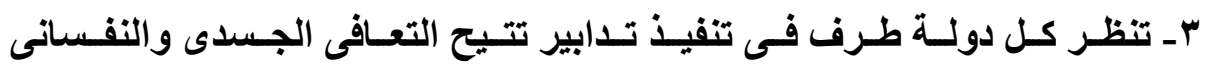

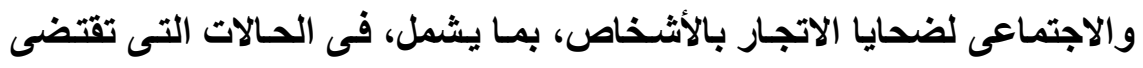

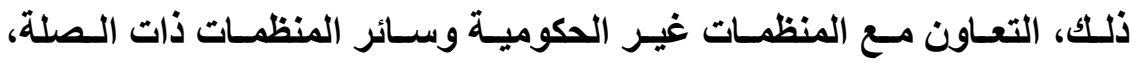
وغيرها من عناصر المجتمع المدنى، وخصوصا توفير ما يلي:

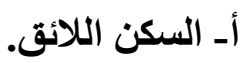
بـ المشورة والمعلومات، خصوصا فيما يتعلق بحقوقهم القانونية، بلغة يمكن لضحايا الاتجار بالأثخاص فهمها. ج- المساعدة الطبية والنفسانية والمادية. 


$$
\text { د ـ فرص العمل والتعليم والتدريب. }
$$

عـ تأخذ كل دولـة طرف بعين الاعتبار، للدى تطبيق أحكام هذه المـادة، سن ونوع جنس ضــايا الاتجـار بالأثـخاص واحتياجـاتهم الخاصـة، ولا سـيما احتياجـات الأطفال الخاصة، بما فى ذلك السكن اللائق والتعليم والرعاية. هـ تحرص كل دولة طرف على توفير السلامة البدنية لضحايا الاتجار بالأشخاص أثناء وجودهم داخل إقليمها. جـ تكفل كل دولة طرف احتواء نظامها القانونى الداخلى على تدابير تتيح لضحايا

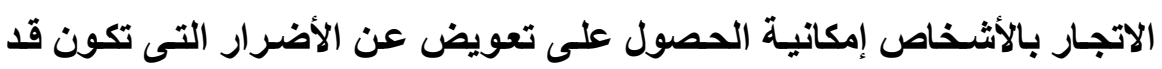

$$
\text { لحقت بهم". }
$$

كمـا أضسافت المسادة V على ضـرورة اهتمسام كل دولـة طرف بضـايا الاتجـار

$$
\text { الموجودين على إقليمها، حيث نصت على: }
$$

" ا - بالإضافة إلى اتخـاذ التدابير المبينة في المـادة 7 من هذا البروتوكول، تنظر كل دولة طرف فى اعتمـاد تدابير تشريعية أو تدابير أخرى مناسبة، تسمح لضحايا الاتجـار بالأشخاص، في الحالات التى تقتضى ذلك، بالبقاء داخل إقليمها بصفة

$$
\text { مؤقتة أو دائمة. }
$$

ץ ـ لـدى تنفيذ الحكم الـوارد في الفقرة ا مـن هذه المـادة، تـلى كل دولـة طرف

$$
\text { الاعتبار الواجب للعوامل الإنسانية والوجدانية". }
$$

وأيـضا أكـدت المـادة ^ على وجـوب حـرص كل دولـة طـرف، يكسون ضـحية

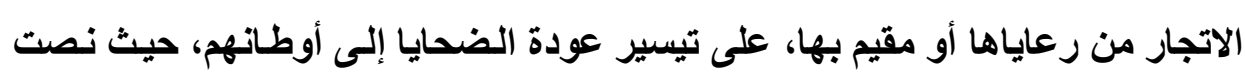
على أن: 
" ا ـ تحرص الدولة الطرف، التى يكون ضحية الاتجار بالأشخاص من رعاياها، أو التى كان يتمتع بحق الإقامة الدائمة فيها وقت دخوله إقليم الدولة الطرف المستقبلة، على أن تيسر وتقبل عودة ذلك الشخص، دون إبطاء لا مسوغ له أو غير معقول، مع إيلاء الاعتبار الواجب لسلامة ذلك الثخص.

r - عندما تعيد دولة طرف ضحية اتجار بالأشخاص إلى دولة طرف يكون ذلك الثخص

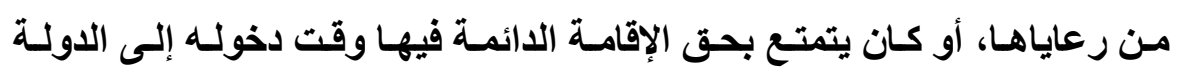
المستقبلة، يراعى فى إعادة ذلك الشخص، إيلاء الاعتبار الواجب لسلامته، ولحالة الإلة أى إجراعات قانونية تتصل بكون الشخص ضحية للاتجـار. ويفضل أن تكون تلك العودة طوعية.

r- بناء على طلب من دولـة طرف مستقبلة، تتحقق الدولة الطرف متلقية الطلب أن تتحقق دون إبطاء لا مسوغ لـه أو غير معقول، ممـا إذا كـان الشخص الذى هو

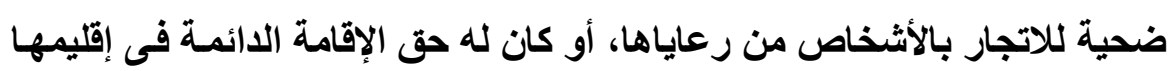
وقت دخوله إلى إقليم الدولة الطرف المستقبلة.

ع ـ تسهيلا لعودة ضحية اتجار بالأشخاص لا توجد لايسه وثثائق سليمة، توافق الدولة الطرف التى يكون ذلك الشخص من رعاياهـا، أو التى كـان يتمتع بحق الإقامـة الدائمة فيها وقت دخوله الدولة الطرف المستقبلة، على أن تصدر، بناء على طلب الدولة الطرف المستقبلة، ما قد يلزم من وثائق سفر أو أذون أخرى، لتمكين ذلك الثخص من السفر إلى إقليمها أو معاودة دخوله. هـ لا تمس أحكام هذه المـادة بأى حق يمنح لضحايا الاتجـار بالأشخاص بمقتضى أى قانون داخلى للاولة الطرف المستقبلة. 
\- لا تمس هذه المادة بأى اتفاق أو ترتيب ثنائى أو متعدد الأطراف منطبق، يحكم كليا

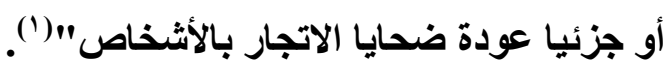

كمـا نـص القـانون العربـى الاسترشــــ لمواجهـة جـرائم الاتجـار بالأثـخاص،

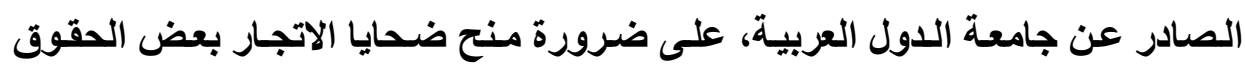

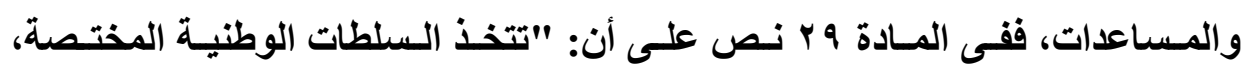

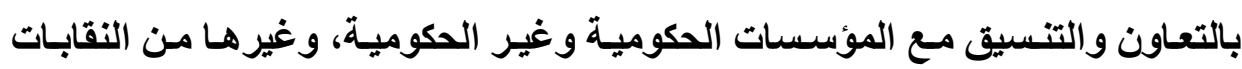

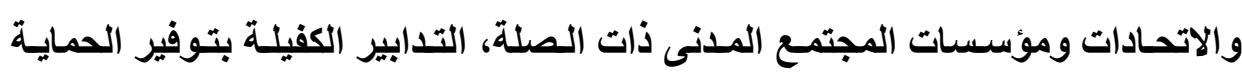
المناسبة لضحية الاتجار وتعمل على تهيئة الظروف المناسبة لمساعدتها على التعافى الجسدى والنفسى والاجتمـاعى، وإعـادة تأهيلهـا ودمجهـا فـى المجتمـع، مـع مراعـاة كرامتها الإنسانية وحقوقها الأساسية".

$$
\text { وفى المادة . ب على أنه: "... كما يراعى كفالة الحقوق الآتية لها: }
$$

ا ـ سلامتها الجسدية والنفسية والمعنوية.

r- - صون حرمتها الثخصية وهويتها.

r- تبصيرها بالإجر اعات الإدارية والقانونية والقضائية ذات الصلة، وحصولها على المعلومات المتعلقة بها بلغة تفهمها. ع ـ الاستماع إليها وأخذ آرائها ومصالحها بعين الاعتبـار، وذلك فى كافة مراحل

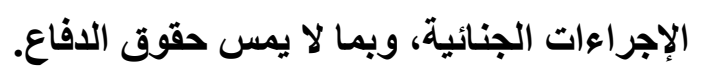

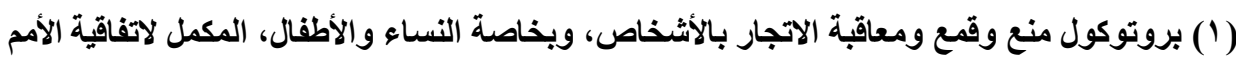

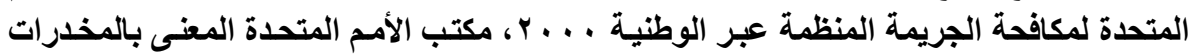

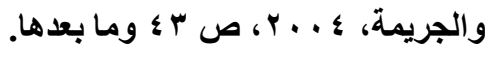
مجلة البحوث القانونيت والإقتصاديت و س 
هـ المسـاعدة القانونيـة، وعلى الأخص الحقى فـى الاسـتعانة بمحسام فى مرحلتى

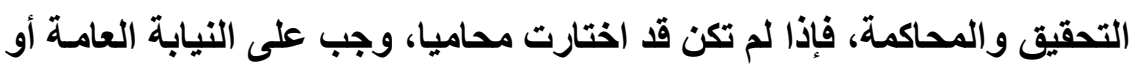

$$
\text { المحكمة بحسب الأحوال أن تندب لها محاميا. }
$$

7ـ حضور العنصر النسائى عنـــ إجـراء التحقيقـات الخاصـة بضحايا الاتجـار مـن النساء.

Vـ العمل على أن تمنع الإجراءات القضائية إعادة تعرض الضحايا، وبصفة خاصـة النساء والأطفال، للإيذاء. ^ـ منح الضحايا الأجاتب إقامة مؤقتة بالدولة، لحين الانتهاء من إجراءات التحقيق

$$
\text { والمحاكمة، واستيفاء كافة حقوقهم". }
$$

ونـصت المـادة ب r علـى أن: "تـوفر السلطات المختصة فـى الدولـة أمساكن

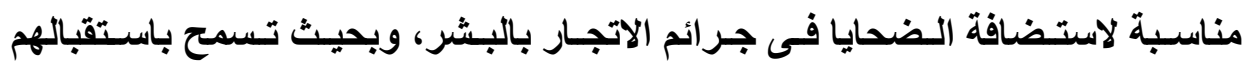

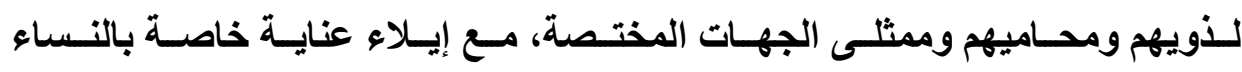

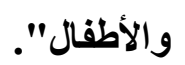

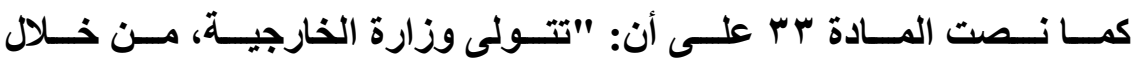

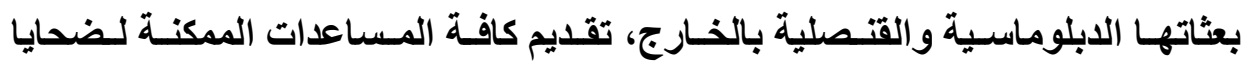
جرائم الاتجار بالبشر من مواطنى الدولة، وذلك بالتنسيق مـع السلطات المختصة فى بـ الدول المعتمدة لاديها، وتهيئة كافة الظروف لحمايتهم وتيسير إعادتهم إلى البلاد بأسرع

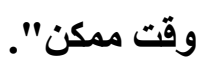

ونصت المادة ؛ ب على أن: "تعمل السلطات المختصة فى الدولة، بالتسسيق مع السلطات المعنية فى الدول الأخرى، على تسهيل عودة الضحايا الأجانب إلى وطنهم،

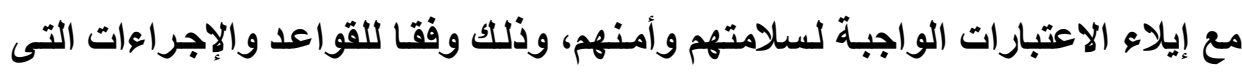
يصدر بها قرار من .........". يلاء الاعبارات 
وأخيرا، نصت المسادة هب على أن: " توفر السلطات المختصة برامج رعايـة

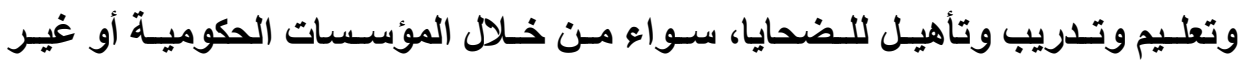

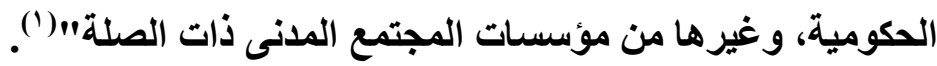

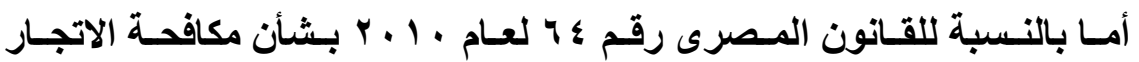

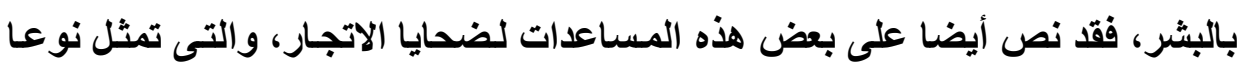

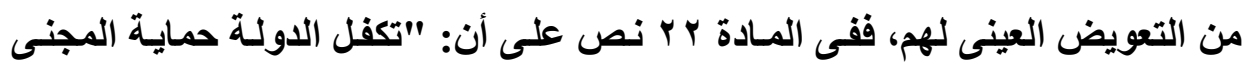

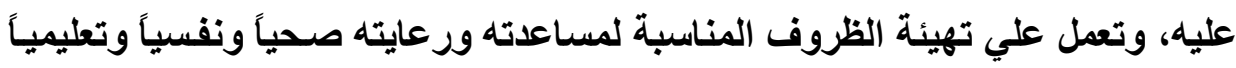

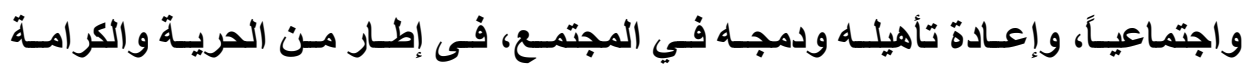

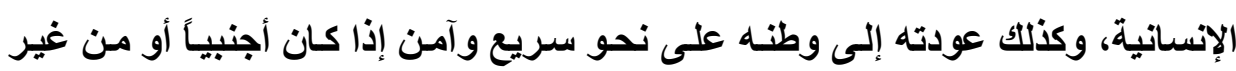

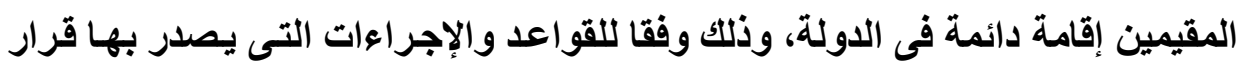

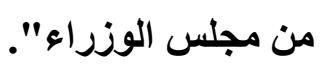

وفى المادة بr على أن: "...كما يراعى كفالة الحقوق الآتية للمجنى عليه: أـ الحق فى سلامته الجسدية والنفسية والمعنوية. بـ الحق فى صون حرمته الثخصية وهويته. ج- الحقى فى تبصيره بـالإجر اءات الإداريـة والقانونيـة والقضائية ذات الصـلة، وحصوله على المعلومات المتعلقة بها. دـ الحق فى الاستماع إليه وأخذ آرائه ومصصالحه بعين الاعتبار، وذلكت فى كافة

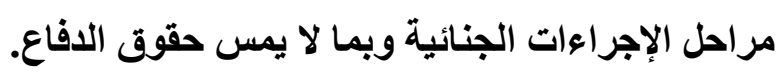


هـ الحق فى المساعدة القانونية، وعلى الأخص الحق فى الاستعانة بمحام فى

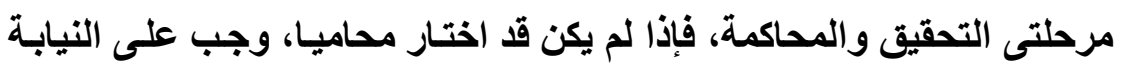

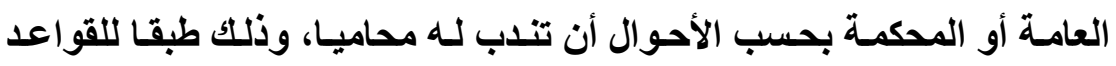

$$
\text { المقررة فى قانون الإجراعات الجنائية، بشأن ندب محام للمتهم...". }
$$

وفى المادة § ب على أن: "توفر الدولة أماكن مناسبة لاستضافة المجنى عليهم

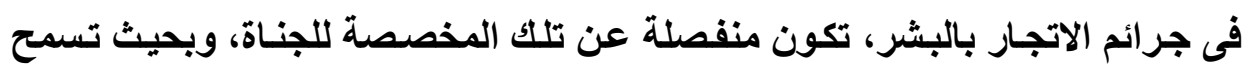
باستقبالهم لذويهم ومحاميهم وممثلى السلطات المختصة، وذلك كله بمـا لا يخل بسائر الضمانات المقررة فى هذا الشأن، فى قانون الطقل أو أى قانون آخر". وفى المادة ه على أن: "تتولى وزارة الخارجية من خلال بعثاتها الابلوماسية

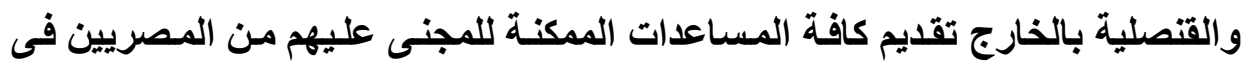
جرائم الاتجار بالبشر، وذلك بالتنسيق مع السلطات المختصة فى الدول المعتمدة للايها، وعلى الأخص، إعـادتهم إلـي جمهوريـة مصر العربية، وعلى نحو آمن وسريع، كمـا تتولى وزارة الخارجية بالتنسيق مع السلطات المعنية فى الدول الأخرى، تسهيل الإعادة الآمنة السريعة للمجنى عليهم الأجانب إلى بلادهم الأصلية".

وأخيرا، فى المادة צ Y على أن: "تقوم السلطات المختصة بتوفير برامج رعاية

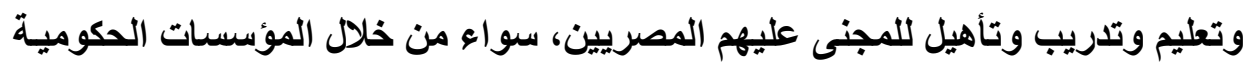

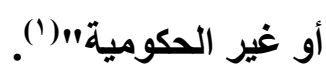

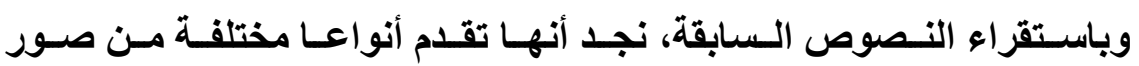
المساعدات والخدمات لضحايا الاتجار بالبشر، تمثل نوعا من التعويض العينى لهم،

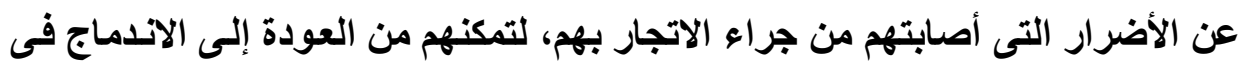
المجتمع، لممارسة حياتهم بشكل طبيعى. 


\title{
المبحث الثالث \\ الطرق التقليدية لالهصول على التعويض \\ والعقبات التى تواجهه
}

\begin{abstract}
تمهيد وتقسيم:
يجب على كل دولـة أن تتـــذ التـابير والإجراءات التى تمكن الضحية مـن

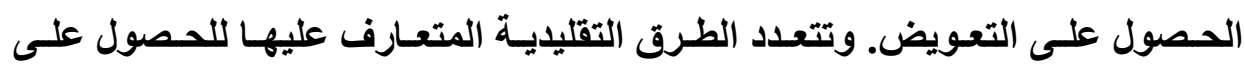

التعويض، حيث يمكن لضحية الاتجار بالبشر أن يرفع دعوى التعويض أمسام المحكمة

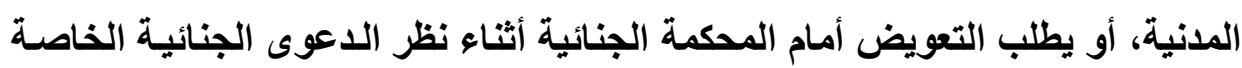

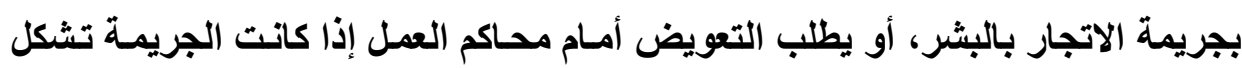
انتهاك لحقوق العمال أو العمل القسرى، وغيره.
\end{abstract}

وعلى الرغم من تعدد هذه الطرق، إلا أن الحصول على التعويض من خلالها يصطدم بعقبات كثيرة تحول دون الحصول عليه. ويناء على ما تقدم، نرى تقسيم هذا المبحث إلى مطلبين على النحو الآتى: المطلب الأول: الطرق التقليدية للحصول على التعويض. المطلب الثانى: عقبات الحصول على التعويض من خلال الطرق التقليدية. 


\section{المطلب الأول \\ الطرق التقليدية للحصول على التعويض}

وفقـا لنص الفقرة 7 من المـادة 7 من بروتوكول منـع وقمـع ومعاقبة الاتجـار

بالأثخاص، وبخاصة النساء والأطفال، المكمل لاتفاقية الأمم المتحدة لمكافحة الجريمـة المنظمـة عبر الوطنيـة، والتى تنص على أن: "تكفل كل دولـة طرف احتواء نظامها القانونى الداخلى على تدابير تتيح لضحايا الاتجار بالأشخاص إمكانية الحصول على الى

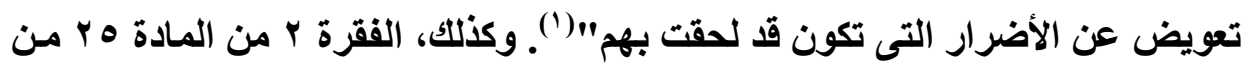
اتفاقية الأمم المتحدة لمكافحة الجريمة المنظمة عبر الوطنية، على أنه: "تضع كل دولة التهن طرف، قواعد إجرائية ملائمة، توفر لضحايا الجرائم المشمولة بهذه الاتفاقية، سبل الحصول على التعويض وجبر الأضرار"().

فيجب على الـدول أن تتخـذ تــابير وإجـراعات مناسبة لتمكين الضحايا مـن

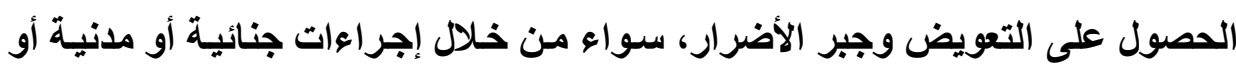

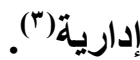

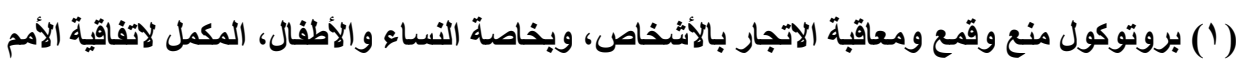

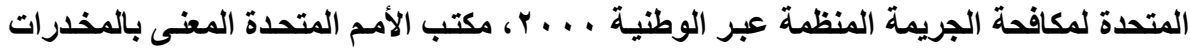

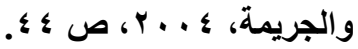

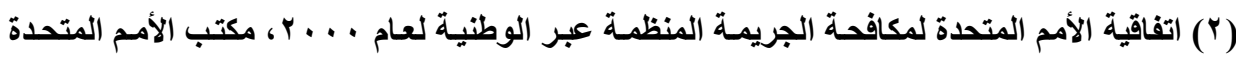

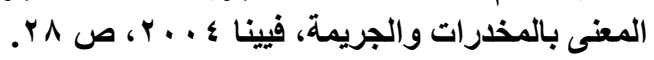

(3) Mohamed Mattar, Expert Consultation, Effective Remedies for Victims of Trafficking in Persons, Convened by the U.N. Special Rapporteur on trafficking in persons, especially women and children, previous reference, P. 14. And Comp. act, European action for compensation for trafficked persons, Guidance on representing trafficked persons in compensation claims, A practical tool for lawyers, counseling centres and service providers, $P .3$. 


$$
\text { ونعرض لهذه الطرق بالتفصيل، على النحو الآتى: }
$$

\section{أولا: المكميمة المدنية}

يمكن لضحية الاتجـار بالبشر أن يحصل على التعويض من خلال رفع دعوى

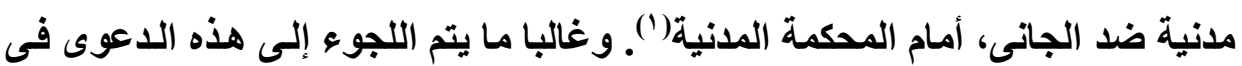

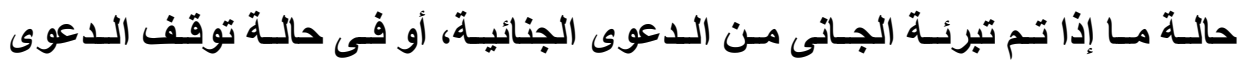

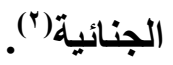

وحتى لو لم ينص على الحق فى رفع الدعوى المدنية فى قوانين بعض الدول،

إلا أنـه يحق للـصية أن يرفـع هذه الـدعوى، طالمـا أصـابه ضـرر أو خسارة، وذلكـ

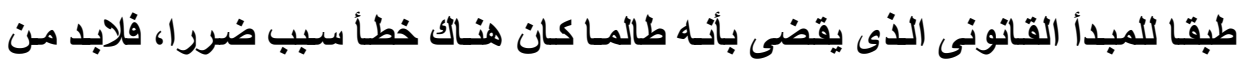

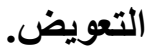

ففى معظم الولايـات القضائية، يمكن أن يحـاكم الشخص جنائيـا، ويـان في

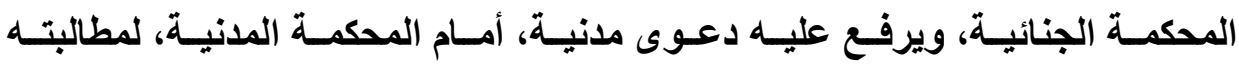

$$
\text { بالتعويض عن الضرر أو الخسارة التى لحقت بالضحية)("). }
$$

(1) Petra Follmar-Otto and Heike Rabe, Human trafficking in Germany, Strengthening Victim's Human Rights, German Institute for Human Rights, 2009, P.65.

(2) Comp. act, European Action for compensation for trafficked persons, Guidance on representing trafficked persons in compensation claims, A practical tool for lawyers, counselling centres and service providers, toolkit on compensation for trafficked persons, No Date, $P .7,8$.

(3) United Nations Office on Drugs and Crime, Global Initiative to Fight Human Trafficking, Anti-human trafficking manual for criminal justice practitioners, Module 13, Compensation for victims of trafficking in persons, 2009, P. 5,6.

$$
\text { مجلة البحوث القانونيت والإقتصاديت ـ }
$$


وعلـى ذلــك، نـصت المــادة rV مـن القــانون النمـوذجى لمكافحسة الاتجــار بالأشخاص، الصادر عن مكتب الأمسم المتحدة المعنى بالمخدرات والجريمـة، على حق

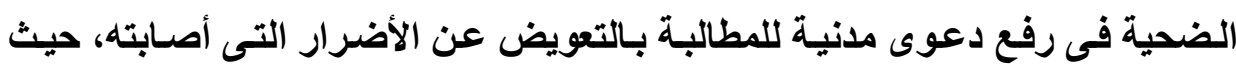
نصت على أنه:

" ا ـ يجب أن يكون لضحية الاتجـار بالأشخاص الحق فى رفع دعوى حقوق مدنيـة،

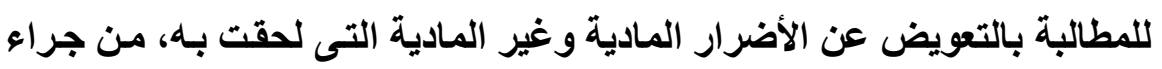
أفعال محددة، باعتبارها أفعالا جنائية بموجب هذا القانون.

r ـ الحق فى متابعة مطالبة مدنية بتعويض عن الأضرار المادية وغير الماديـة لا يتأثر بوجود إجراءات دعوى جنائية قائمة، فيما يتعلق بالأفعال نفسها تتأتى من جرائها

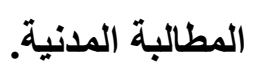

r- وضع الهجرة الخـاص بالضحية، أو إعادتهـ إلى وطنه، أو أى غيـاب آخر للضحية

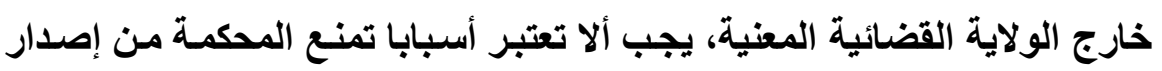
أمر بدفع تعويض بمقتضى هذه المادة".

وقد جـاء فى التعليق على المـادة ب مـن القـانون النموذجى أنـه ينبغى لأى

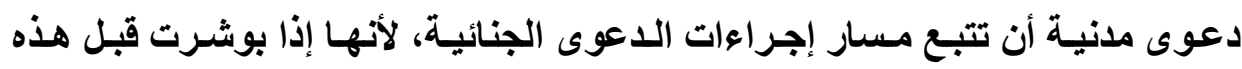
الأخيرة، فإنه لابد من إرجائها إلى حين إتمام الدعوى الجنائية) ('). وقد أعطت المادة و ب من القانون العربى الاسترشادى لمكافحة جرائم الاتجـار

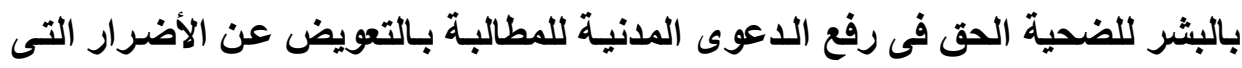

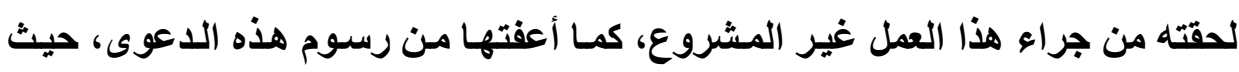
(1) قانون نموذجى لمكافحة الاتجار بالأثخاص، مكتب الأمم المتحدة المعنى بالمخدرات والجريمة،

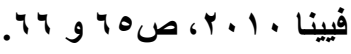


نـصت على أن: "تعفى الـضحية مـن رسـوم الـدعوى المدنيـة التى ترفعهـا للمطالبـة بالتعويض عن الضرر الناجم عن استغلالها فى إحدى جرائم الاتجار بالبشر" (1"). كمـا أعطى قــانون الولايــات المتحـدة الأمريكيـة الخـاص بإعـادة التكليـف

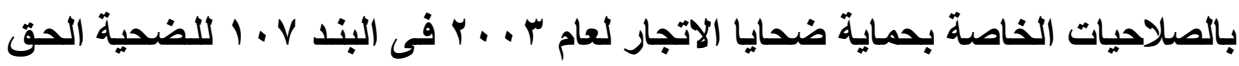
فى رفع دعوى مدنية للمطالبة بـالتعويض، فنص فيه على أنسه: "يجوز لأى فرد يقع ضحية اتجـار بالأشخاص أن يرفع دعوى مدنيـة على مقترف هذا الجرم إلى محكمة محلية مختصة فى الولايات المتحدة، ويجوز لله أن يحصل على تعويض عمـا لحق بـه من أضرار، وكذلك على مبلِغ معقول للدفع أتعـاب المحامى. وأى دعوى مدنيـة ترفع بمقتضى هذا البند توقف أثناء مواصلة النظر فى أى دعوى جنائية ناشئة عن الواقعة منس نفسها، التى يكون فيها المدعى هو الضحية"(؟). كمـا نصت على هذا الحق أيضا

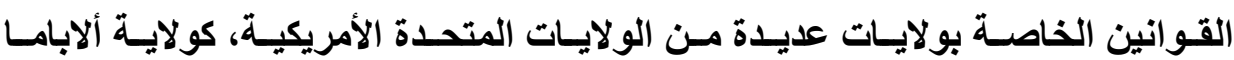
وأريزونـا وكاليفورنيا وكونيكتكت ومقاطعة كولومبيا، وغيرها").

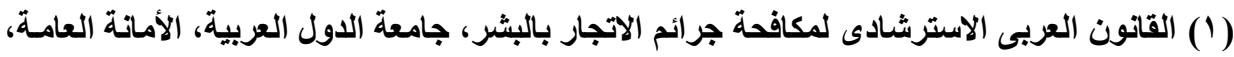

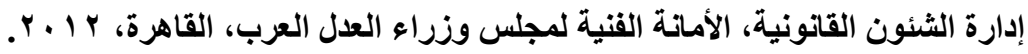

Trafficking victims protection reauthorization act of 2003 "TVPRA"(r)

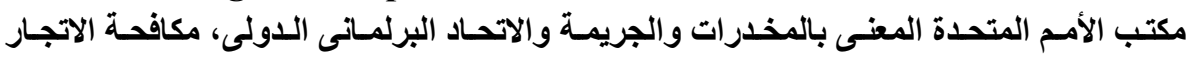

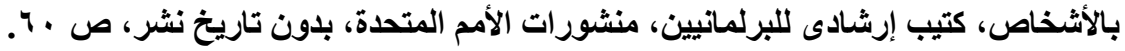

(3) Alabama. CODE § 13A-6-157 (2011).ARIZ. REV. STAT. ANN. § 13807 (2011). CAL. CIV. CODE $§ 52.5$ (2011).CONN. GEN. STAT. § 52571I (2011).D.C. CODE $§$ 22-1840 (2011). Also, Mohamed Y. Mattar, Incorporating the Five Basic Elements of a Model Antitrafficking in Persons Legislation in Domestic Laws: From the United Nations Protocol to the European Convention, previous reference, P. 35. 
كما يعفى القانون العمـانى المتضرر من مصروفات رفع الدعوى المدنية التى

يطالب من خلالها بتعويض ما أصابه من ضرر (').

وجدير بالذكر، أن القواعد العامة للتعويضات تنطبق أيضا على ضحايا الاتجـار

بالبشر، فمثلا، تمـنح المـادة الثالثة مـن قـانون الإجراءات الجنائية الجزائرى ضـحايا

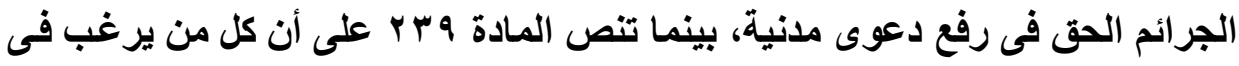
رفع دعوى مدنية، وفقا للحق المكفول له فى المادة الثالثة، بداعى أنه ضحية لجناية أو لو له جنحة، يجوز له أن يطالب بـالحق المدنى فى الجلسة نفسها التى ينظر فيها القضية. أيضا لكل من تعرض لأذى بسبب جريمة ما، الحق فى رفع دعوى مدنية منفصلة لطلب

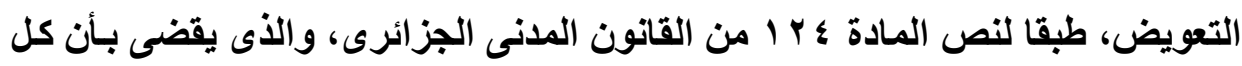
فعل ينتج عنه ضرر هو سبب للتعويض. وتنص المادة • 1 من القانون القطرى على أن للمحكمة الجنائية المختصة بنظر الاعوى الجنائية الخاصة بقضية الاتجار الصلاحية القضائية للنظر فى الدعوى المدنية

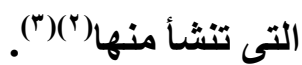
ونـرى مـع البعض أنـهـ وإن كـان الـصول على التعـويض مـن خـلال اللجـوء

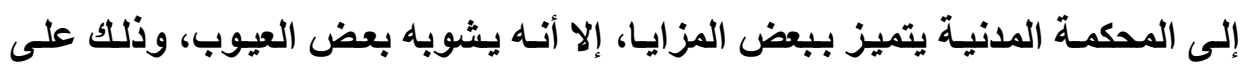

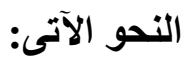

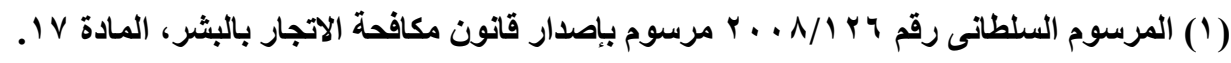

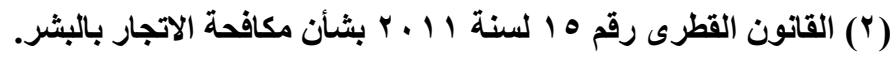

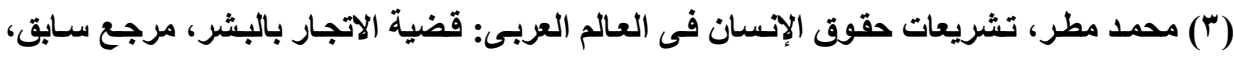
ص ا' 


\section{مزايا اللجوء إلى المحكمة المدنية}

1- تهذف هذه الدعوى إلى ضمان تعويض الضحية.

r- هناتك ما يكفى من الوقت خـلال هذه اللدعوى لمناقشة الأضرار سـواء العامـة أو الخاصة الناتجة عن جريمة الاتجار.

r- - هنايك أيضا إمكانية للتشاور مع الخبراء والمتخصصين، مثنل الأطباء خلال هذه

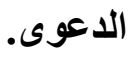

ع ـ كذلك اللجوء إلى هذه الدعوى يمكن الضحية من الحصول على التعويض، بـالرغم

من تبرئة الجانى فى الاعوى الجنائية، كمـا يمكن جلب الأدلة من الدعوى الجنائية إذا صدر حكم فيها ضد الجانى إلى الدعوى المدنية.

هـ نظرا لأن الضحية تكون طرفا فى الدعوى المدنية، فيمكنها استئناف الحكم أو الطعن عليه(')

\section{عيروب اللبرو إلى المكمة المدنية}

ا- طول مدة إجراعات الدعوى المدنية، حيث تظل قائمة لسنوات عديدة(؟). r- - يجب أن يبدأ إجراءاتها الضحايا أنفسهم، والذين يقع عليهم عبئ إثبات واقعة الاتجار والضرر وعلاقة السببية.

(1) Comp. act, European Action for compensation for trafficked persons, Guidance on representing trafficked persons in compensation claims, A practical tool for lawyers, counselling centres and service providers, toolkit on compensation for trafficked persons, No Date, P. 7,8.

(2) Elaine Pearson, Human traffic, Human rights: Redefining victim protection, Anti- Slavery international organization, 2002, P. 81.

$$
\text { مجلتة البحوث القانونيت والإقتصاديت 9 } 9 \text { ـ }
$$


r- فى حالـة خسارة الـدعوى، سـتتحمل الضحية تكاليفها، بمـا فيهـا أتعـاب محسمى

$$
\text { الجانى. }
$$

ع ـ قـ لا تسمح بعض الدول ببقـاء ضـحايا الاتجـار فيها للقيـام بـإجراعات الـدعوى

المدنية، بسبب مخالفة قوانين الهجرة(')

هـ ـ ويجب أن يكون الجانى معروفا ومحددا حتى ترفع عليه الدعوى المدنية، ويمكن أن ترفع الدعوى على الجـانى لو كان شخصا منفردا أو الشركة أو المنظمـة التى استظلت الضحية، ويجب أن يكون للى الجـانى بعض الأمـوال التى تمكنه من دفع التعويض، ويتوقف مقدار التعويض على القـانون المدنى فى كل دولة، وإن كـان الغالب أن يشمل التعويض عن الضرر المادى والأدبى.

ج- ويلاحظ أن بعض الضحايا يمكن أن ترى أن الدعوى المدنية بديل جيد عن المطالبة بالتعويض فى الاعوى الجنائية، ولكن تزال الضحية فى حاجة إلى تحديد المدعى عليه ومعرفته لرفع الاعوى المدنية عليه. كذلك يمكن أن تسأل المحكمة المدنية، لماذا لم يحاكم المدعى عليه فى محكمة جنائية طالما أن الضرر المزعوم قد حدث

$$
\text { نتيجة أنشطة إجرامية؟! }
$$

V- - ويلاحظ أنسه فى كثير مـن الولايـات القضائية، يختلف عبئ الإثبات فى الدعوى الجنائية عن الاعوى المدنية. فمن الممكن أن يحكم ببراءة الشخص فى الدعوى الجنائية، ومع ذلك يظل فى الإمكان مطالبته بالتعويض فى المحكمة المدنية. وهذا غالبـا مـا يكون بسبب أنسه فـى هذه الولايـات القضائية، يجب أن يكـون الإثبـات

(1) Comp. act, European Action for compensation for trafficked persons, Guidance on representing trafficked persons in compensation claims, A practical tool for lawyers, counselling centres and service providers, toolkit on compensation for trafficked persons, No Date, P. 7,8.

$$
\text { 70. مجلت البحوث القانونيت والإقتصاديت }
$$


المطلوب فى المحكمة الجنائية على نحو لا يدع مجالا للشك، بينما يكفى الاحتمسال

$$
\text { فى الإثبات فى الاعوى المدنية)('). }
$$

ثانيا: المحكمة الجنائية

إذا كان الأصل أن دعوى التعويض لا تختص بنظرهـا سوى المحـاكم المدنيـة، إلا أنه إذا كان الفعل الضار يشكل جريمة، فقد أجاز القانون استثناع لمن لحقه ضرر من

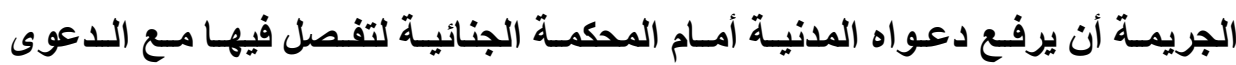
الجنائية، وذلك لتبسيط الإجراعات، ولوحدة الفعل الذى تنشأ عنه الدعوى("). وعلى ذلك، يمكن لضحية الاتجار بالبشر أن تحصل على تعويض عن الأضرار التى أصابتها من جراء الاتجار بها أو استغلالها من خلال المحكمة الجنائية، حيث يمكن أن تحكم له المحكمة الجنائية بالتعويض.

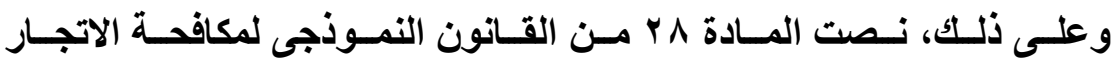
بالأشخاص، الصادر عن مكتب الأمم المتحدة المعنى بالمخدرات والجريمـة، والمتعلقة بالتعويض بأمر المحكمة، على أنه: " ا ـ فى حال إدانة مذنب بارتكاب جرم بمقتضى هذا القانون، يجوز للمحكمة أن تـأمر الجانى بدفع تعويض للضحية، إضافة إلى أى عقوبة أخرى تـأمر بها المحكمة، أو

بلالا منها.

(1) United Nations Office on Drugs and Crime, Global Initiative to Fight Human Trafficking, Anti-human trafficking manual for criminal justice practitioners, Module 13, Compensation for victims of trafficking in persons, previous reference, P. 5,6.

$$
\text { (Y) محمد صبحى نجم، المرجع السابق، ص } 9 \text { • ؛ . }
$$

$$
\text { مجلة البحوث القانونيت والإقتصاديت }
$$


ץ - حين فرض أمر بدفع تعويض، على المحكمة أن تضع فى الحسبان موارد الجانى،

ومقدرته على دفع التعويض، وعليها أن تجعل للتعويض الأولوية على الغرامة. rـ يجب أن يكون الهدف من الأمر بدفع التعويض هو إصلاح مـا لحق بالضحية من أذى أو خسارة أو ضـرر بسبب مـا فعلـه الجـانى. ومـن الجـائز أن يشتمل الأمـر بالتعويض على دفع مبلغ مقابل ما يلى:

أ ـ تكاليف المعالجة الطبية أو الجسدية أو النفسية أو العقلية اللازمة للضحية. بـ تكاليف العلاج الجسدى أو المهنى الطبى أو إعادة التأهيل اللازمة للضحية.

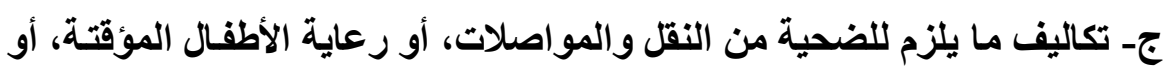
السكن المؤقت، أو نقل الضحية إلى مكان إقامة آمن مؤقت. دـ فقدان الـذخل والأجـور المستـقة وفقـا للقـانون الـوطنى واللـوائح التنظيميـة

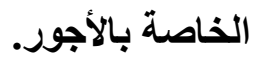
هـ الرسوم القانونيـة، وغيرهـا مـن التكاليف أو النفقـات المتكبدة، بمـا فى ذلكـ

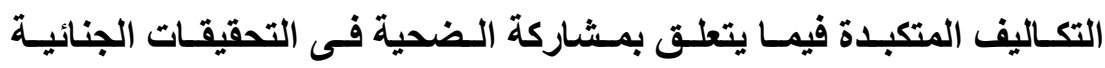

$$
\text { وإجراءات المقاضاة. }
$$

وـ دفع تعويض عن الأضرار غير المادية، المتأتية عن الأذى المعنوى أو البدنى

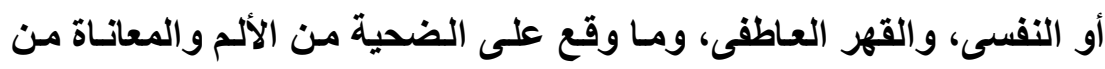

$$
\text { جراء الجريمة التى ارتكبت بحقه. }
$$

ز- أى تكاليف أو خسائر أخرى تكبدتها الضحية كنتيجة مباشرة لخضوعه للاتجار به، مما تقدره المحكمة على نحو معقول. 
ع - يجوز للاولة أن تستخدم كل الوسـائل المتاحة بمقتضى القانون الداخلى، من أجل إنفاذ أى أمر بالتعويض يصدر بمقتضى هذه المادة. هـ وضع الهجرة الخاص بالشخص الضحية، أو إعادتهـ إلى وطنه، أو أى غيـاب آخر للضحية خارج الولاية القضائية، لا تعتبر أسبابا تمنع المحكمة من أن تصدر أمرا بدفع تعويض بمقتضى هذه المادة. צ- عندما يكون الجانى موظفا عموميا قام بتصرفاته، التى تثكل فعلا جرميا بمقتضى هذا القانون، في إطار سلطة فعلية أو ظاهريـة تابعة للاولـة، يجوز للمحكمة أن تأمر الدول بدفع تعويض للضحية وفقا للتشريع الوطني. ويجوز أن يشمل أى أمر يصدر بشأن دفع الدولة تعويضا بمقتضى هذه المادة دفع مبلغ يستوعب كل البنود،

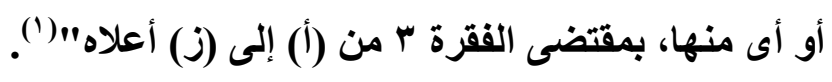

كمـا نـص إعـلان المبـادئ الأساسـية لتوفير العدالـة لـضحية الجريمـة وإسـاءة استعمال السلطة، فيما يخص جبر الضرر، وذلك فى المـادة 9 منـه على أنهـ: "ينبغى للحكومات إعادة النظر فى ممارساتها ولوائحها وقوانينها، لجعل رد الحق خيارا متاحسا لإصدار حكم به فى القضايا الجنائية، بالإضافة إلى العقوبات الجنائية الأخرى "(؟). وتنص الفقرة الأولى من المـادة ه V من نظام رومـا الأساسـى للمحكمة الجنائية

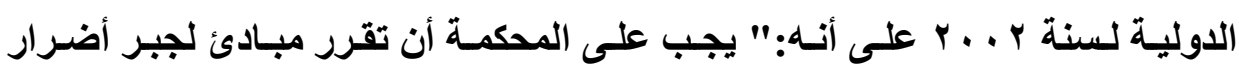
الضحايا، بما يشمل رد الحقوق والتعويض وإعادة التأهيل. وعلى هذا الأسـاس، يمكن

(1) قانون نموذجى لمكافحة الاتجار بالأشخاص، مكتب الأمم المتحدة المغنى بالمخدرات والجريمة،

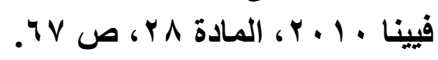

(2) Declaration of Basic Principles of Justice for Victims of Crime and Abuse of Power, Resolution adopted by the General Assembly, November 29, 1985, UN Doc. A/RES/40/34. 
للمحكمة فى حكمها، سواء بناء على طلب أو بمبادرة منها فى الظروف الاستثنائية، أن تحدد نطاق ومدى أى ضرر أو خسارة أو إصابة لحقت بالضحية"(').

وفى بعض الدول، يمكن للشرطة أن تقدم طلب للتيابـة العامـة ليشمل إجراءاتها المطالبـة بـالتعويض للمجنى عليـه. وفـى مـصر، يسمح قـانون الإجـراءات الجنائيـة

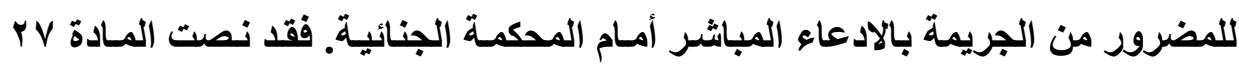

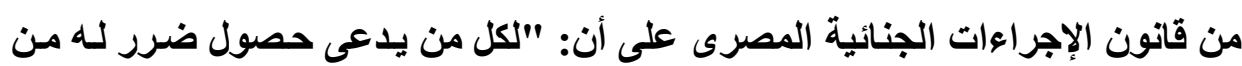
الجريمة، أن يقيم نفسه مدعيا بحقوق مدنية فى الثكوى التى يقدمها إلى النيابة العامـة أو أحد مأمورى الضبط القضائى". وفى المـادة 99 1 مكرر من نفس القانون على أن

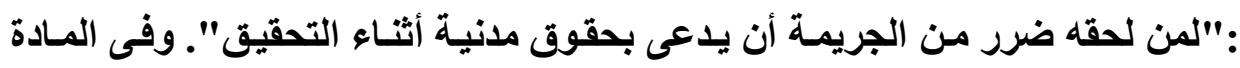
اهP على أن: "لمن لحقه ضرر من الجريمة أن يقيم نفسه مدعيا بحقوق مدنية أمسام المحكمة المنظورة أمامها الدعوى الجنائية".

ونرى مع البعض، أنه وإن كـان الحصول على التعويض من خلال اللجوء إلى

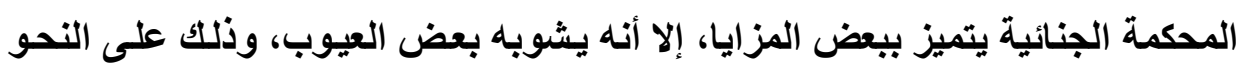
الآتى:

\section{هرايا البجوs إلى المككمة الجنائية:}

ا - يلتزم الجـانى قانونـا، فى الحساتات التـى تـنجع فيهـا الـدعوى، بـفع التعويض

\section{للضحية.}

r - يقع عبئ إثبات الواقعة الإجرامية على النيابة العامة، وليس على الضحية. r- يكون الحكم فى الدعوى الجنائية أسرع من الدعوى المدنية.

(1) Article 75 (1) (Reparations to Victims) of the Rome Statute of the International Criminal Court (2002).

مجلة البحوث القانونيت والإقتصاديت ـ 
؛- يكون هنالك إمكانية للضغط على الجـانى لدفع التعويض عن طريق الحكم عليه

بالسجن لمدة أطول إذا لم يقم بدفع التعويض، وفى بعض الدول، تعدل الدولة

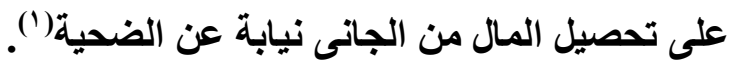

\section{عيرب البجوs إلى المكمة البنائية:}

إن التعويض من خلال الإجراعات الجنائية غير متاح بالنسبة لكثير من الضحايا،

$$
\text { ويرجع ذلك إلى عدة أسباب أهمها: }
$$

1- تعقيد وحداثة التشريعات المتعلقة بمكافحة الاتجار بالبشر، وبالتالى، صعوبة محاكمة الجانى، نظرا لاختلاف تفسيرات القضاة لهذه القوانين.

r - أيضا هناك صعوبات تتعلق بالإثبات، خاصة مع عدم الرغبة من جانب الضحايا

$$
\text { أو الثهود فى التعاون فى هذه الإجراعات. }
$$

r- استحالة الحصول على تعويض كامل للضرر، بسبب غياب أو عدم كفاية الأموال

أو المصادر المملوكة للجانى(')

ـ - غالبـا مـا يوجد ميعـاد محدد لإمكانيـة المطالبـة بـالتعويض مـن خـلال إجراءات

$$
\text { المحكمة الجنائية. }
$$

(1) Comp. act, European Action for compensation for trafficked persons, Guidance on representing trafficked persons in compensation claims, A practical tool for lawyers, counselling centres and service providers, toolkit on compensation for trafficked persons, No Date, P. 7.

(2) Lisanne de Weerd, Compensation for trafficked persons from state funds: Are compensation funds appropriate for trafficked persons? A critical examination of four state compensation funds in Europe, Master thesis, Amsterdam, 2011, P. 24.

$$
\text { مجلت البحوث القانونيت والإقتصاديت ه }
$$


0ـ إذا كاتت القضية معقدة، فغالبا ما يحيلها القاضى للمحكمة المدنية.

$$
\begin{aligned}
& \text { آ- إذا لم يمكن إثبات الواقعة فلا يحكم بالتعويض. } \\
& \text { V- الضحية لا تكون طرفا فى الدعوى ('). }
\end{aligned}
$$

^- ـ وفى كل الأحوال، يجب أن يعرف ويحدد الجـانى بواسطة السلطات المعنيـة،

$$
\text { ويجب أن يثبث ارتكابه للجريمة حتى يمكن الحكم عليه بالتعويض. }
$$

خلاصـة الأمـر، فبإذا كـان فى بعض الولايـات القضائية يمكن للضحية أن يرفع

دعوى مدنية للمطالبة بالتعويض فى نفس الوقت الذى تنظر فيه الدعوى الجنائية، ففى أنظمة أخرى، يمكن أن يحكم بالتعويض كجزء من العقوبة من خلال المحكمة الجنائية.

وفى بعض الولايات القضائية الأخرى، يمكن أن تجعل دفع الجانى للتعويضات للضحية

$$
\text { عاملا مخففا من العقوبة) (؟) }
$$

\section{ثالثا: هماكم العمل}

لقد جـاء فـى التعليق على المـادة ^ ب مـن القـانون النمـوذجى لمكافحـة الاتجـار

بالأشخاص، والتى تتعلق بالتعويض بأمر المحكمة، أنه: "يجوز فى بعض الدول، وفى حالات معينة، إلى جانب الإجراءات الجنائية، أن تلجـأ الضحية إلى رفع القضية إلى بلى بلى

(1) Comp. act, European Action for compensation for trafficked persons, Guidance on representing trafficked persons in compensation claims, A practical tool for lawyers, counselling centres and service providers, toolkit on compensation for trafficked persons, No Date, P. 7.

(2) United Nations Office on Drugs and Crime, Global Initiative to Fight Human Trafficking, Anti-human trafficking manual for criminal justice practitioners, Module 13, Compensation for victims of trafficking in persons, previous reference, P. 4.

$$
\text { مجلتة البحوث القانونيت والإقتصاديت }
$$


محكمة مختصة بقضايا العمل والعمـال. وقد تقوم منظمـات العمل بدور مهم فحى هذا الثأن، وفى تقديم المساعدة إلى الضحايا فى الحصول على جبر الأضرار التى لحقت بهم، أو على التعويض اللازم عنها، أو كليهما. ولكن يتعين لأى دعوى عمالية أن تتبع

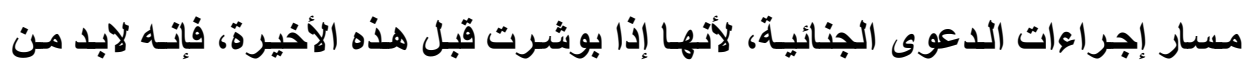
تأجيلها إلى حين إتمام الدعوى الجنائية"(').

يتضـح مـن هـا النص، أنسه فـى بعض الولايـات القضـائية، تكـون المحكمـة الرئيسية المختصة بقضايا الاتجـار بالأثـخاص، والتى يكـون محلهـا العمل وحقوق

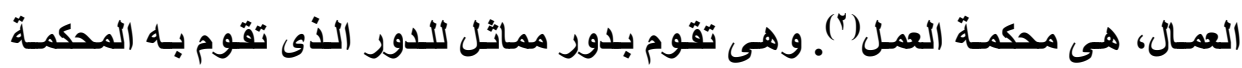
المدنية، فمعايير الإثبات المطلوبـة فى الحالتين واحدة، والهـف من هذه الدعوى هو جبر الضرر الذى يلحقه صاحب العمل بالعامل(").

إلا أن الفرق الجوهرى بين التعويض من خلال محساكم العمل، والتعويض من خلال المحساكم المدنيـة، هو خصوصية موضوع النزاع، والتى تتعلق بحقوق العـال،

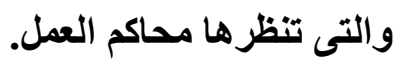

(1) قانون نموذجى لمكافحة الاتجار بالأشخاص، مكتب الأمم المتحدة المعنى بالمخدرات والجريمة،

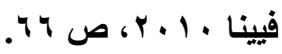

(2) Jean Bruggeman \& Elizabeth Keyes, Meeting the Legal Needs of Human Trafficking Victims, An Introduction for Domestic Violence Attorneys \& Advocates, the American Bar Association, 2009, P. 17.

(3) United Nations Office on Drugs and Crime, Global Initiative to Fight Human Trafficking, Anti-human trafficking manual for criminal justice practitioners, Module 13, Compensation for victims of trafficking in persons, previous reference, P. 6,7. 
إذن، فتستخدم هذه الآلية فى التعويض لضحايا الاتجـار لغرض الاستفلال فى العمل. ويلاحظ أنه فى كثير من الدول، لا ينظر إلى الدعارة على أنها نوع أو نشاط من الأن

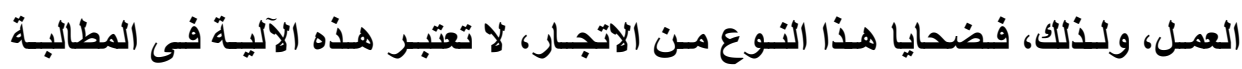
بالتعويض مجدية بالنسبة إليهم (')

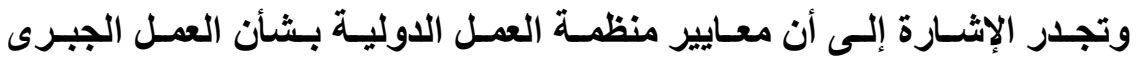

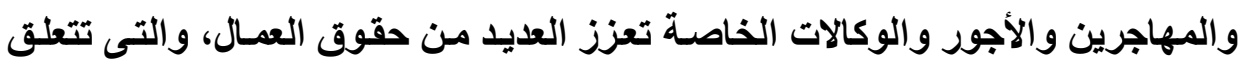

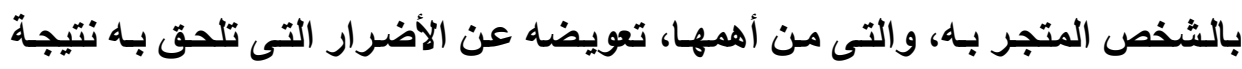

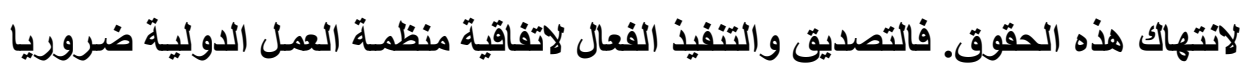

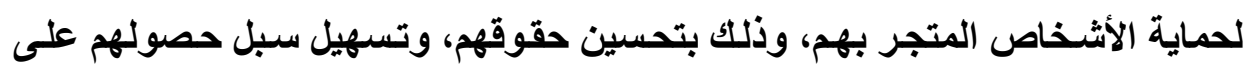

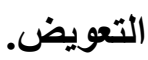
فالضحية لها حقوق أساسية بموجب قانون العمل، حتى ولو لم يكن هناك عقد

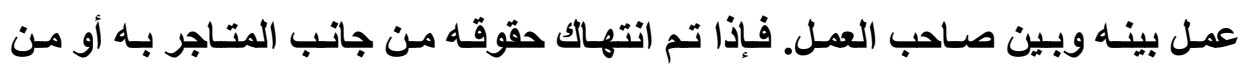
استظله، يمكن مطالبة هذا الأخير بالتعويض من خلال محاكم العمل. ويمكن أن تؤسس هذه المطالبة على الأجور غير المدفوعة للعامل، أو عدم

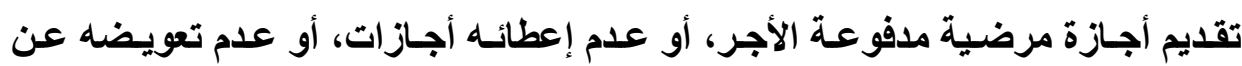

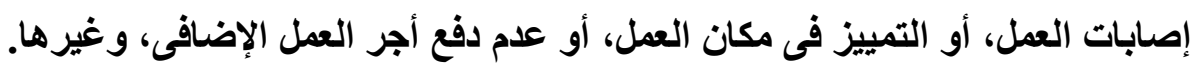
وفيما يتعلق بحساب الأجور غير المدفوعة للعامل أو الضائعة، والتى تكون

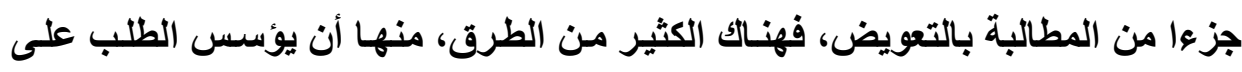

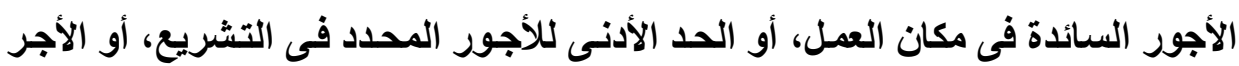

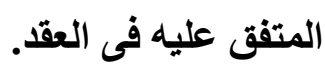
(1) Lisanne de Weerd, previous reference, P. 25. 
ويتميز اللجوء إلى محساكم العمـل للحصول على التعويض، فـى أن وسـائل أو

معايير الإثبات المطلوبة فى هذه الدعوى، أقل وأسـهل من تلك المطلوبـة فى الدعوى الجنائية. كمـا أن أصـحاب العمل، غالبـا، مـا يكون مؤمنـا عليهم مـن المسئولية تجـاه العمال، مما يجعل الحصول على التعويض أمرا يسيرا.

إلا أنـه، في كل الأحوال، يجب أن يكون مرتكب الفعل غير المشروع معروفـا ومحددا، ويمتلك أموالا ومصادر حتى يمكنهـ دفع التعويض، وجبر الضرر الذى لحق

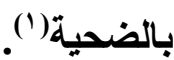

(1) United Nations Office on Drugs and Crime, Global Initiative to Fight Human Trafficking, Anti-human trafficking manual for criminal justice practitioners, Module 13, Compensation for victims of trafficking in persons, previous reference, P. 6,7.

مجلت البحوث القانونيت والإقتصاديت 909 


\section{الإطاب الثانى \\ عقبات الهصول على التعويض هن خلال}

الطرق التقاليدية

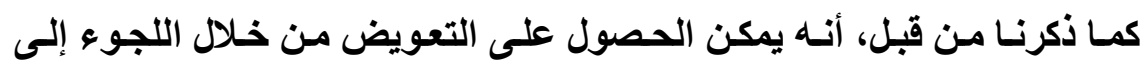

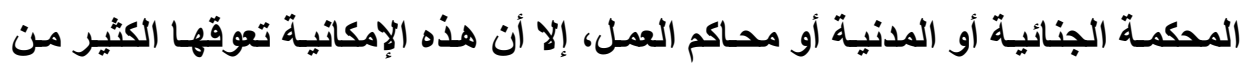

$$
\text { العقبات فى الواقع العملى. }
$$

فبالإضافة إلى العيوب التى ذكرناهـا بمناسبة الحديث عن كل من هذه الطرق،

فهناك الكثير من العوامل الأخرى التى تؤثر على فعالية اللجوء إلى الإجراءات الجنائية

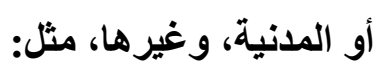

1 ـ البعض مـن الأثـخاص المتــاجر بهـم لا يـرون أنفسهم كضحايا لاتجـار بالبشر،

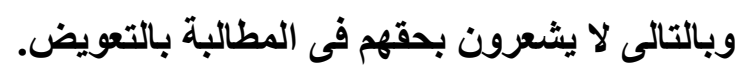

r - خوف الضحية من طلب التعويض من المتاجرين بهم، خشية الانتقام منهم نتيجة

$$
\text { ضغطهم على الضحايا أو تهديدهم. }
$$

r- - خوف الضحية من رد فعل أقاربهم وأصدقائهم.

ع - إحباط ضحية الاتجار بالبشر من تعقيد وبيروقراطية إجراءات المطالبـة القضائية

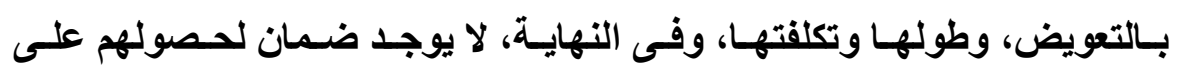

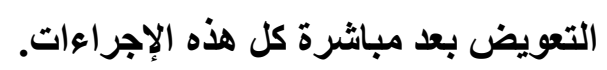

هـ ـ الحالة النفسية السيئة التى يمرون بها، ورغبتهم فى نسيان الجريمـة البشعة التى

$$
\text { وقعت عليهم (1). }
$$

(1) Comp. act, European Action for compensation for trafficked persons,

Findings and results of the European Action for compensation for=

مجلة البحوث القانونيت والإقتصاديت 
צ- الفشل فى تحديد ومعرفة الأشخاص المتجر بهم، وعدم منحهم إقامـة فى الدولة

$$
\text { التى تتم فيها إجراعات الحصول على التعويض. }
$$

V- - عدم وجود الدعم الكافى لاسترداد معافاة الثخص المتجر به.

^ــ نقص المعلومات والمعرفة من جانب الضحايا.

9 - عدم وجود المساعدة القانونية المجانية.

• 1 - نقص القدرات والمعرفة والخبرة مـن جاتب السلطة القضائية والمحامين فى القى التماس التعويض للأشخاص المتاجر بهم.

11 ـ عدم كفاية برامج حمايـة الشهود لضمان سـلامة وأمن الأثـخاص المتاجر بهم،

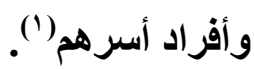

r ا ـ أن الدول لا تقوم بتوفير أو تقديم المعلومات للضحايا حول حقهم وآليات الحصول على التعويض، لأنهم لن يكونـوا قـادرين على الحصول على التعويض، إلا بعد

$$
\text { معرفتهم لهذه المعلومات المهمة (؟). }
$$

ب ا ـ غالبا ما تكون الإجراعات القضائية والإداريـة معقدة، مـع عدم وجود المسـاعدة

$=$ trafficked persons, Toolkit on compensation for trafficked persons, 2012, P. 38- 41.

(1) Joy Ezeilo, Report of the Special Rapporteur on trafficking in persons, especially women and children, United Nations, General assembly, 2011, P. 6.

(2) Tonny Moses and Radoslaw Lukasz, previous reference, P. 18. Also, Heather, Nicole, Amy, and Lisa, Study of HHS programs serving human trafficking victims, US department of health and human services, Final Report, December 2009, P. 18.

مجلت البحوث القانونيت والإقتصاديت ا 
القانونية، خاصة، لمن لم تكن لديه دراية كافية بالإجراءات القانونية الواجبة

$$
\text { الإتباع للحصول على التعويض. }
$$

؛ ا - يثترط للحصول على التعويض أن تكون الضحية مقيمة فى الدولة التى يسعى

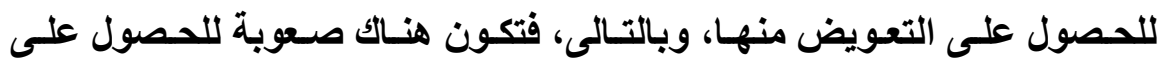

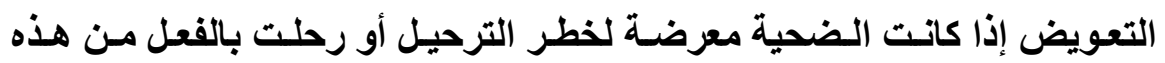

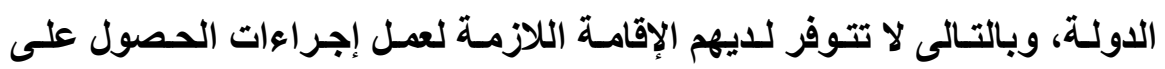

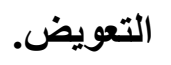

ه - ـ وحتى إذا تم الحصول على حكم بالتعويض ضد الجناة، فمن الصعب للغاية تنفيذ

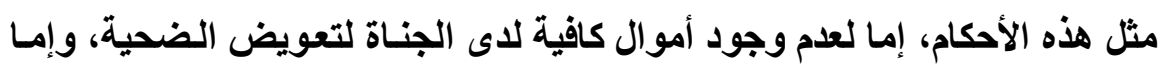

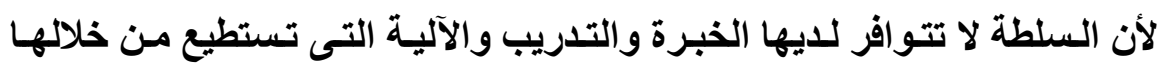
تجميل ومصادرة أموال الأشخاص المتجرين.

17 ا - طول وتأخر المحاكمات، والتى غالبا ما لا تصدر حكمها إلا بعد أن يكون الضحية

$$
\text { غادرت الدولة التى وقعت فيها الجريمة. }
$$

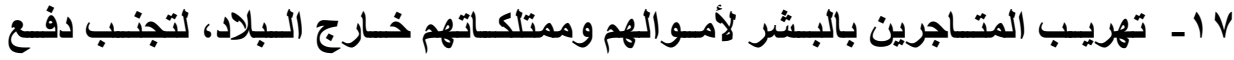

$$
\text { التعويض (') }
$$

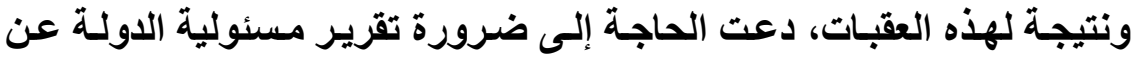

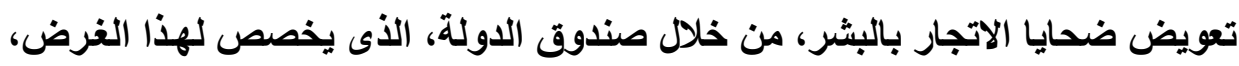
وهذا ما سنتناوله فى الباب الثانى من هذا البحث.

(1) Comp. act, European action for compensation for trafficked persons, Guidance on representing trafficked persons in compensation claims, A practical tool for lawyers, counseling centres and service providers, $P$. 4. 


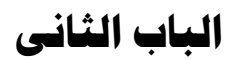

\section{تعويض ضحايا الاتجار بالبشر هن خلال}

صندوق الضشمان

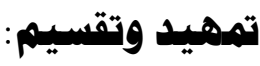

نتيجة لوجود العقبات السابق الإثارة إليها، والتى تعوق حصول الضحية على التى

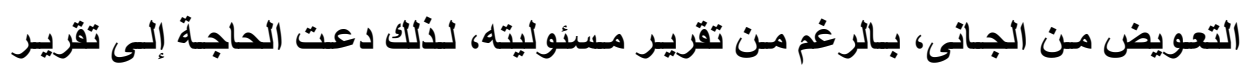

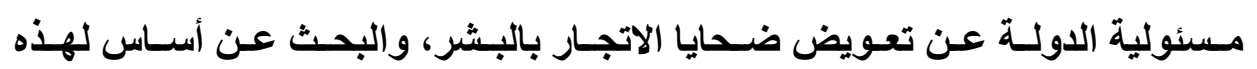

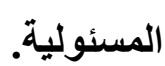

وبعد الانتهاء إلى تقرير مسئولية الدولة عن تعويض الضحايا، نجد أن آلية

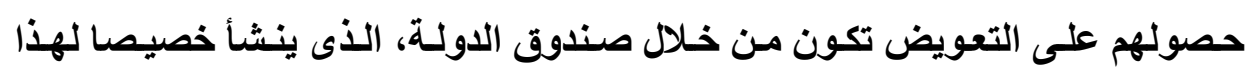

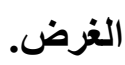
وبناء على ما تقدم، سنقسم هذا الباب إلى فصلين، على النحو الآتى: الفصل الأول: تقرير مسئولية الدولة عن تعويض ضحايا الاتجار بالبشر وأسساس

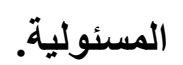

الفصل الثانى: صندوق الضمان كوسيلة لتعويض ضحايا الاتجار بالبشر. 


\title{
الفصل الأول \\ تقرير هسئولية الدولة عن تعويض ضحايا الاتجار بالبشر \\ وأساس المسئولية
}

\begin{abstract}
تقسيم:
نبين فى هذا الفصل مدى مسئولية الدولة عن تعويض ضحايا الاتجار بالبشر ، البهل

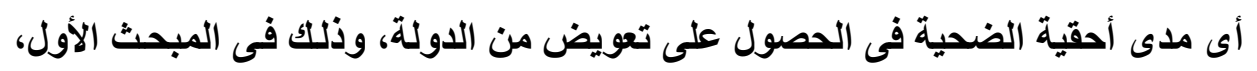

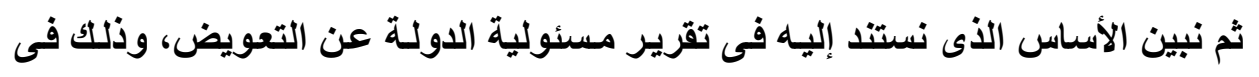

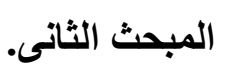




\section{المبحث الأول}

\section{تقرير مسئولية الدولة عن تعويض}

\section{ضحايا الاتجار بالبشر}

إذا كان من الثابت أن لضحية الاتجار بالبشر حق اقتضاء التعويض من الجـانى، باعتباره المتسبب فى ما تكبده من خسائر مادية، وأضرار جسدية، وأخرى معنويـة من جراء الجريمة، إلا أنه قليلا مـا يتحقق ذلك من الناحية العملية، نظرا لأن إعمـال هذا الحق يقتضى بالضرورة معرفة الجـانى، مـع قيـام مسئوليته بموجب حكم قضائى نافذ، مع قرتـه على دفع التعويض، ولكنتـا نجد فى حالات كثيرة أن الجانى يظل مجهولا، سواء من ناحية المجنى عليـه، أو من ناحية السلطـات، وبالتالى، تعجز الضحية عن استيفاء حقها فى التعويض، بل فى أوقات كثيرة يتم معرفة الجانى ولكن يعجز عن دفع التعويض المستحق، رغم جميع الإجراءات التى اتخذتها الدولة فى سبيل الضغط عليه

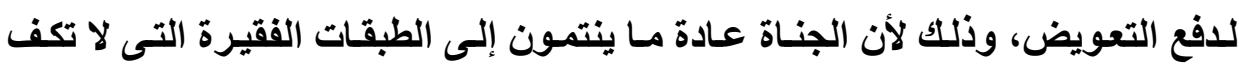
مصادر دخلها لتعويض المجنى عليهم (1).

إذن، فى معظم الأحوال يكون الجـانى غير معروف، أو وضعه المسالى لا يسمح بتعويض الضحية، ومن هنـا جـاوت فكرة مسئولية الدولة عن تعويض المجنى عليه.

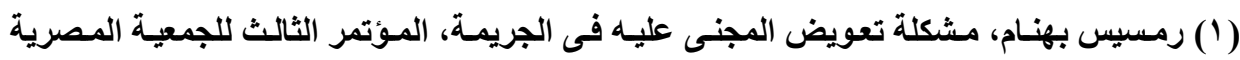

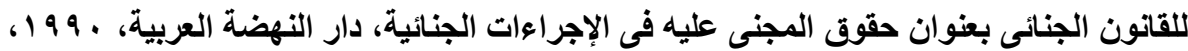

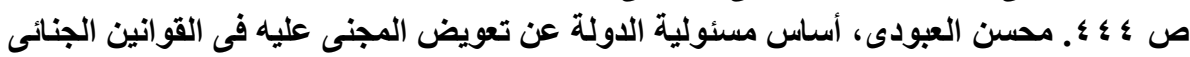

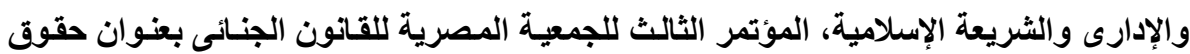

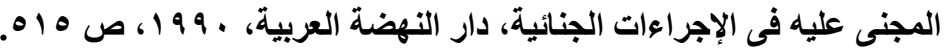


فأمام عجز كل السبل المعروضة فى التشريعات المقارنة فى تحقيق رغبة المجنى عليه فى الحصول على حقه فى التعويض المناسب، الذى يساهم على الأقل فى إزالة بعض الآثار الخاصة بالجريمة، فقد نشأ اتجاه يهذف إلى تقرير حق المجنى عليه فى الحصول

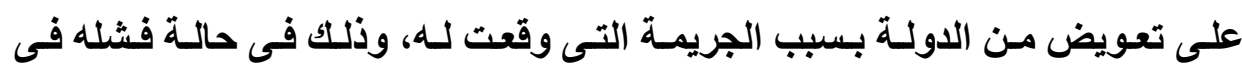
الحصول على التعويض من الجانى (')

وعلى ذلكت، نـص إعلان المبـادئ الأسـاسية لتـوفير العدالـة لـضحايا الجريمـة وإساءة استعمال السلطة على أنه: " | 1 ـ عندما يقوم الموظفون الحكوميون وغيرهم من الوكلاء الذين يتصرفون بصفة رسمية أو شبه رسمية بمخالفة القوانين الجنائية الوطنيـة، ينبغـى أن يحصل الضحايا على تعويض مـن الـول التى كـان موظقوهـا أو وكلاؤها مسئولين عن الضرر الواقع. وفى الحالات التى تكون فيها الحكومـة التى حدث العمل أو التقصير الاعتدائي بمقتضى سلطتها قد زالت من الوجود، ينبغى للاولـة أو الحكومة الخلف أن تقوم برد الحق للضحايا. 1 ـ حيثما لا يكون من الممكن الحصول على تعويض كامل من المجرم أو من مصادر أخرى، ينبغى للاول أن تسعى إلى تقديم تعويض مالى إلى:

(1) عبد الرحمن خلفى، مدى مسئولية الدولة عن تعويض ضحايا الجريمة (الأساس والنطاق)، دراسة

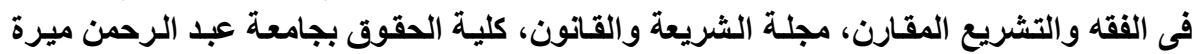

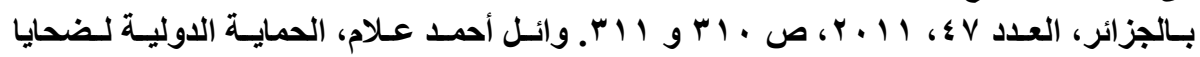

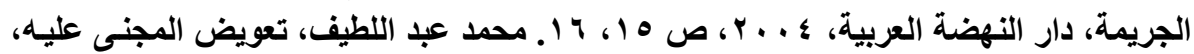

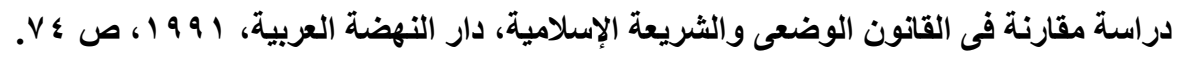




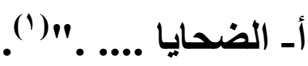

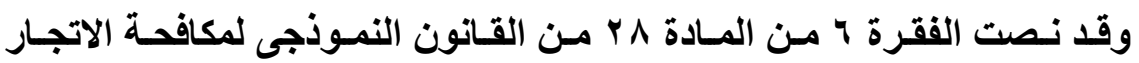

بالأشخاص على أنه: "عندما يكون الجـانى موظفاً عمومياً قام بتصرفاته، التى تشكل فعلا جرميا بمقتضى هذا القانون، في إطار سلطة فعلية أو ظاهريـة تابعة للاولـة، يجوز للمحكمة أن تأمر الدول بدفع تعويض للضحية وفقا للتشريع الوطنى. ويجوز أن يشمل أى أمر يصدر بشأن دفع الدولـة تعويضاً بمقتضى هذه المـادة دفع مبلـغ يستوعب كل البنود، أو أى منها، بمقتضى الفقرة ب من أ إلى ز أعلاه"(؟).

إذن، فمن واجب الدولـة أن تقدم التعويضات المناسبة لضحية الاتجار بالبشر

التى لم تتمكن من الحصول على التعويض من الجانى، لاسيما وأن الدولة لم تتمكن من حمايته ووقايته من وقوع الجريمة. ومن هنا كان لابد من إنثاء نظام لتعويض الضحية من جانب الدولة، فتم إنشاء صناديق للتعويضات، تهدف إلى تعويض ضحايا الاتجـار بالبشر عن الأضرار التى أصابتهم من جراء الاتجار بهم واستغلالهم، فى حالة عجزهم عن الحصول على تعويض من الجانى، سواء لعدم مقرته المالية أو لعدم القبض عليه أو عدم تحديد هويته أو لعدم إدانته(").

(1) Declaration of Basic Principles of Justice for Victims of Crime and Abuse of Power, Resolution adopted by the General Assembly, November 29, 1985, UN Doc. A/RES/40/34.

$$
\begin{aligned}
& \text { (ץ) قانون نموذجى لمكافحة الاتجار بالأثخاص، مكتب الأمم المتحدة المعنى بالمخدرات والجريمـة، }
\end{aligned}
$$

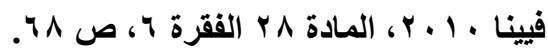

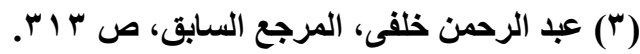

$$
\begin{aligned}
& \text { مجلت البحوث القانونيت والإقتصاديت }
\end{aligned}
$$




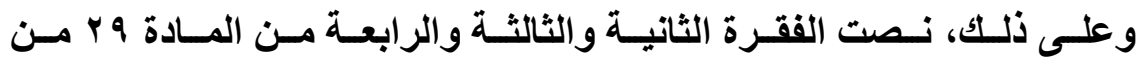

القـانون النمـوذجى لمكافحة الاتجـار بالأشـخاص على أنسه: "Y - يجب على السلطة المختصة ضمان إتاحة الإمكانية لضحايا الاتجـار بالأشخاص لتقديم طلب التماسـاً لدفع التعويض لهم بمقتضى هذه المادة، حتى وإن لم يتم تحديد هوية الجانى أو القبض عليه أو إدانته.

r- يستخدم هذا البند، حيث يجب العمل على إنشاء صندوق محدد لهذا الغرض. لغرض

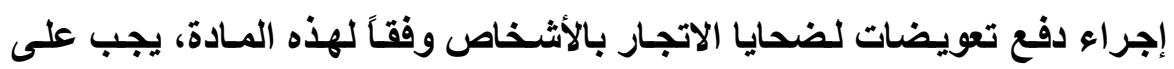
السلطة المختصة إنشاء صـندوق لـصالح الـضحايا، وكـلك تعيسين المسئولين الإداريين للصندوق. ويقبل المسؤولون الإداريـون تلقى المبالغ التى تدفع إلى الصندوق من: - (الصنا أـ الأموال المخصصة للصندوق وفقاً للقانون المالى المعنى؛ بـ الأمـوال المصادرة والعوائد المتأتية من بيع البضائع أو الموجودات المالية المصادرة بمقتضى أحكام القانون الوطنى؛ ج- المدفوعات الطوعية أو المنح أو الهبات المقدّمة إلى الصندوق؛ دـ الإيرادات أو الفوائد أو الأرباح المستمدة من استثمارات الصندوق؛ هـ أي مصدر آخر يسميه المسئولون الإداريون عن الصندوق. ع - يستخدم هذا البند، حيث يوجد مسن قبل صـندوق مناسب لـدفع التعويضات إلى الضحايا. يجب على السلطة المختصة ضمان أن يكون للى المسئولين الإداريين 
عن الصندوق الصلاحية للدع مبالغ التعويض لضحايا الاتجـار بالأشخاص، وفقاً

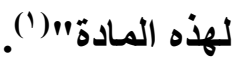

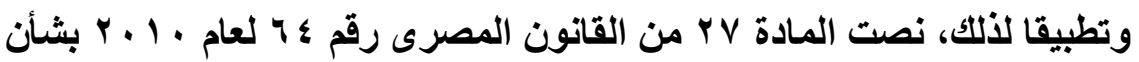
مكافحة الاتجـار بالبشر على أنـه: " ينشأ صندوق لمساعدة ضحايا الاتجـار بالبشر، تكون لـه الثخصية الاعتباريـة العامـة، يتبع رئسيس مجلس الـوزراء، ويتولى تقديم المساعدات المالية للمجنى عليهم، ممن لحقت بهم أضرار ناجمـة عن أى من الجرائم المنصوص عليها في هذا القانون. ويصدر بتظيم هذا الصندوق و تحديد اختصاصاته الأخرى وموارده ومصادر تمويله قرار من رئيس الجمهورية. وتؤول حصيلة الغرامـات المقضي بها فى الجرائم المنصوص عليها فى هذا القانون، والأموال والأدوات ووسـائل النقل التـى يحكم بمـصادرتها إلى الصندوق مباشـرة، وللـصندوق أن يقبل التبرعـات والمنح والهبات من الجهات الوطنية والأجنبية"(؟). يتضـح مسن النصوص السـابقة، أنسه يوجــ اعتراف دولسى بمسئولية الدولـة عن تعويض الضحايا، وبموجب هذه المسئولية، أنشأت العديـا مـن الدول صـناديق لتعويض الضحايا عن الأضرار المادية والمعنويـة التى أصـابتهم مـن جراء الجريمـة، والتى عجز الجـانى عن تعويضهم عنها، وتتمثل مصادر تمويـل هذه الصناديق فى: الأموال المصادرة والعوائد المتأتيـة من بيع البضائع أو الموجودات المالية، والأدوات ووسائل النقل المصادرة بمقتضى أحكام القانون الوطنى، والتبرعات والمنح والهبات

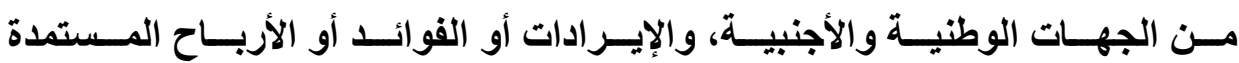

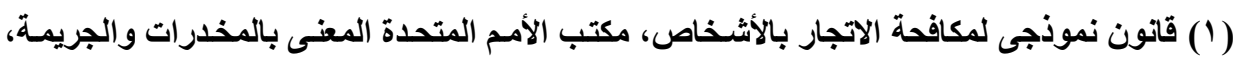

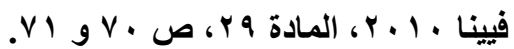

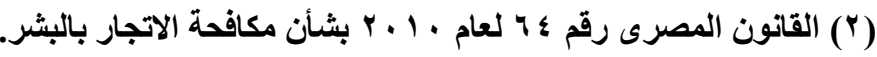


من استثمارات الصندوق، وأيضا الغرامسات المحكوم بها على الجانى لصالح الدولةة، بل إنـه على المحكمة أن تجعل للتعويض الأولويـة على الغرامـة، وهو مـا نصت عليه الفقرة الثانية من المـادة ^ ^ من القـانون النموذجى لمكافحة الاتجـار بالأشخاص على أنه: " ا ـ حين فرض أمر بدفع تعويض، على المحكمة أن تضع فى الحسبان موارد الجـانى ومقدرتـهـ على دفـع التعـويض، وعليهـا أن تجعل للتعـويض الأولويـة على

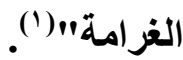




\section{المبحث الثانى}

\section{أساس مسئولية الدولة عن تعويض الضحايا}

إن مسئولية الدولة عن منع ووقف العمل غير المشروع وتعويض المضرور من

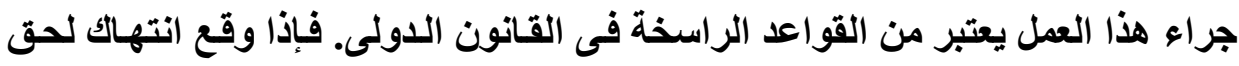
من حقوق الإنسان تقوم مسئولية الدولة، فتلتزم بتعويض الضحية عن الاضضرار التى التى

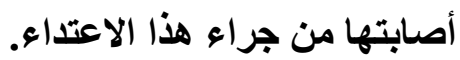

ولا شكك فى أن الاتجار بالبشر يشكل انتهاكا خطير الحقوق الإنسان، ولذك تتحمل

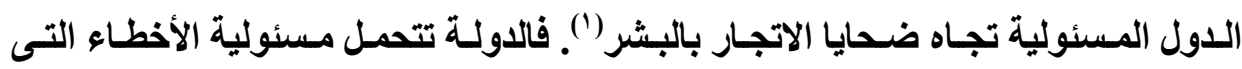

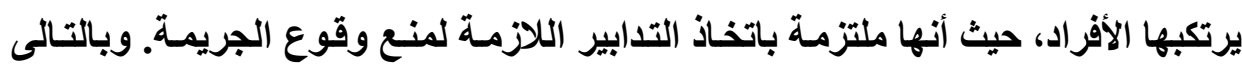

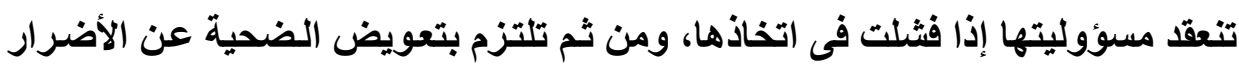
التى أصابتها من جراء الاتجار بهاب("). وقد ثار الخلاف بين الفقهاء بشأن أساس مسئولية الدولة عن تعويض الضحية،

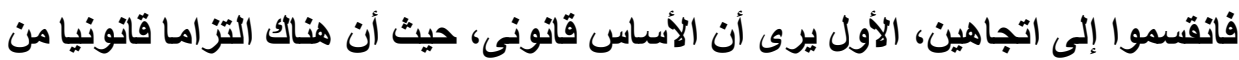

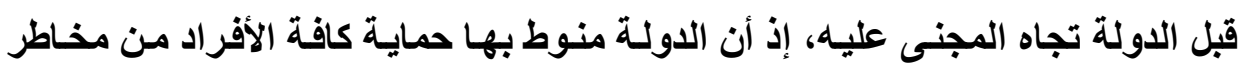

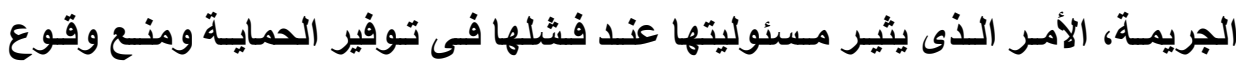

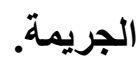

(1) Lisanne de Weerd, previous reference, P. 16,17.

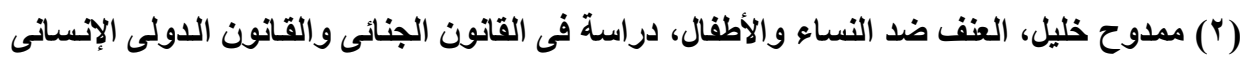

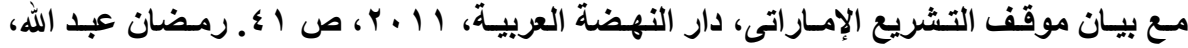

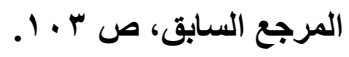

STV مجلت البحوث القانونيت والإقتصاديت 
أما الاتجاه الثانى، فيرجع مسئولية الدولة على أساس اجتمـاعى، فالدولة حينمـا تقوم بتعويض المجنى عليه إنما تفعل ذلك بناء على قواعد التضامن الاجتمـاعى، حيث أنها تلتزم أدبيـا بالمشاركة فى تخفيف الآلام والمعانـاة التى يعانى منهـا المجنى عليه المضرور من الجريمة. ونعرض لهذين الاتجاهين بالتفصيل على النحو الآتى:

\section{أولا: الأساس القانونى}

ويتمثل فى أن هنالك التزامـا قانونيا يقع على عاتق الدولة بمنع وحمايـة كافة الأفراد مسن وقوع الجريمـة، فِاذذا فشلت فـى منـع وقوعهـا، تقوم مسسئوليتها وتلتـزم بتعويض ضحية الجريمة.

فيستند هذا الأسـاس إلى فكرة وجود عقد ضـنى بين الفرد والدولـة، يلتزم بمقتضاه الفرد بأداء الضرائب المقررة عليه إلى الدولة، فى مقابل قيام الدولة بمكافحة الجرائم و حماية وتوفير الأمن للأفراد، لاسيما وأنها تحتكر حق العقاب، و تمنـع الأفراد من حمل السلاح واقتضاء وحماية حقوقهم بنفسهم، وبالتالى، فإن فثلت الدولة فى منع وقوع الجريمة وأصيب الفرد بأضرار من جرائها، فتكون الدولة بـللك قد أخلت بالعقد الضمنى، وتصبح بالتالى ملتزمة قانونا بتعويض كل الأضرار التى لحقت بالضحية من

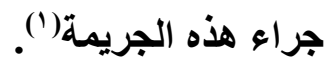

ومـن ناحيـة أخرى، فبإن الدولـة تفرض على الأفراد القيـام ببعض الواجبـات

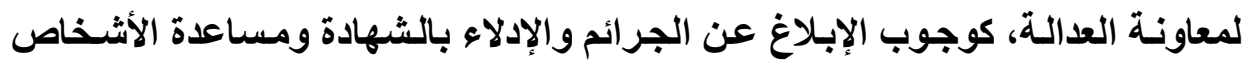

(1) محسن العبودى، المرجع السابق، ص 17 هـ TVY مجلت البحوث القانونيت والإقتصاديت 


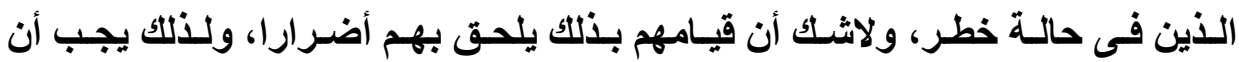
تعوضهم الدولة حتى لا يترددوا فى تقديم المساعدة ومعاونة العدالة('). كذلك، ليس من المنطقى أن تستفيد الدولة من وقوع الجريمة بتحصيل الغرامات

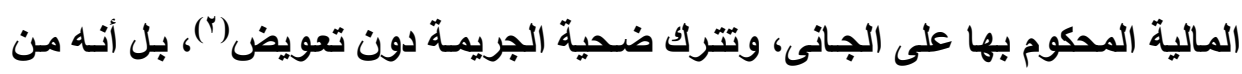
غير العدل أن تساهم الدولـة فى إعسار الجـانى من خلال فرض عقوبـات مالية عليه تحول دون حصول الضحية على التعويض. هذا فضلا عن الأجر الذى تعطيه الدولة للسجين مقابل عمله أثناء فترة عقوبته، وكان من الأولى أن تخصم منه نسبة لتعويض

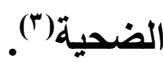

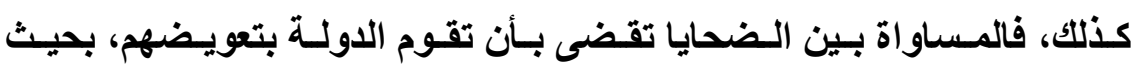
لا يتوقف الأمر على الحظ والمصادفة بحسب مـا إذا كـان الجـانى معروفـا أو مجهولا، مقبوضا عليه أو لا يزال حرا، ميسورا أو معسرا(؛). إذن، فمؤدى الأسـاس القـانونى لالتزام الاولـة بـالتعويض يجعل التعويض حقـا

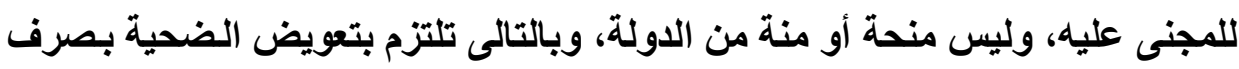
النظر عن حاجته أو مستوى دخله الاجتماعى(0).

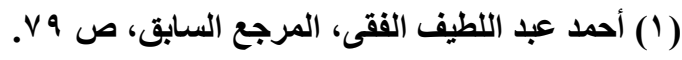

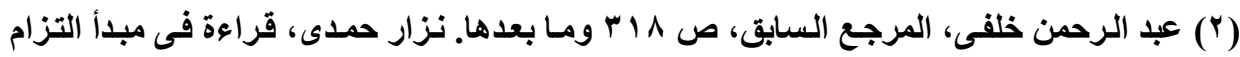

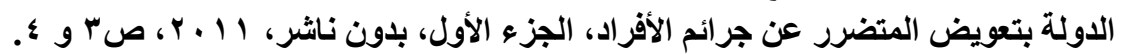

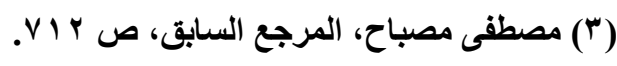

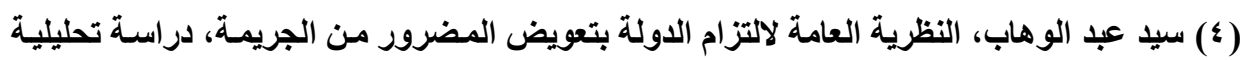

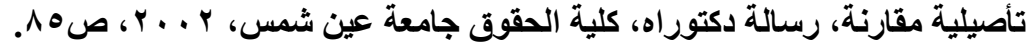

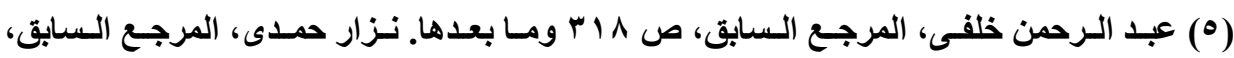

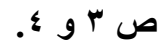

TVY مجلت البحوث القانونيت والإقتصاديت 


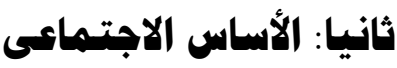

إذا كان الأسساس التقليدى لمسئولية الدولة بالتعويض، سواء ذلك المبنى على أساس الخطأ أو بدون خطأ لا يكفى فى أغلب الأحوال لتعويض ضحايا الاتجار بالبشر،

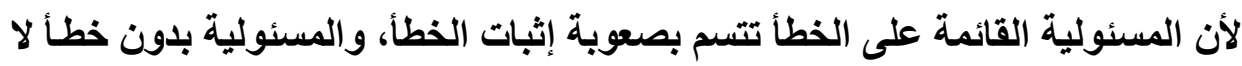

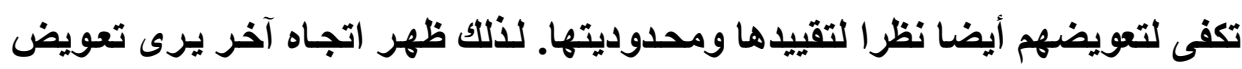

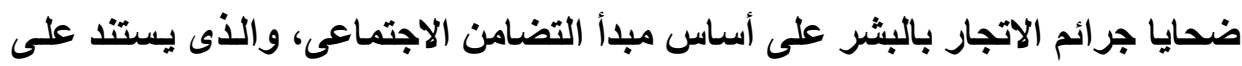

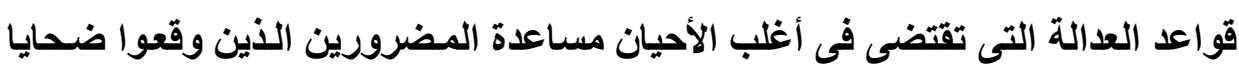

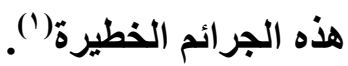

و وعلى ذلك، فالدولة عندما تقوم بتعويض ضحايا الجريمة، إنما تقوم بذلك بنـاء

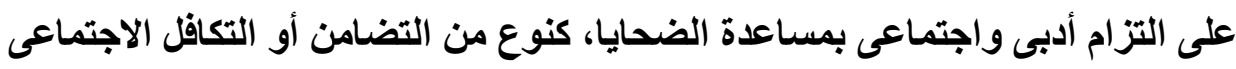

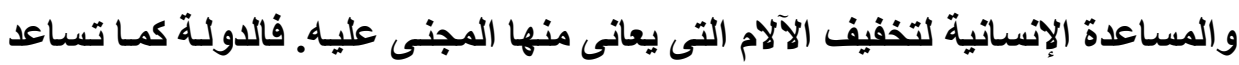

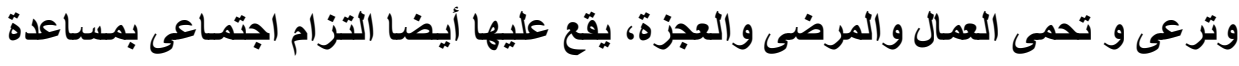

$$
\text { وتعويض المضرورين من الجرائم(") }
$$

فالدولة بناء على هذا الأساس ملزمة ببذل كل مـا يمكنها لمنع وقوع الجريمة،

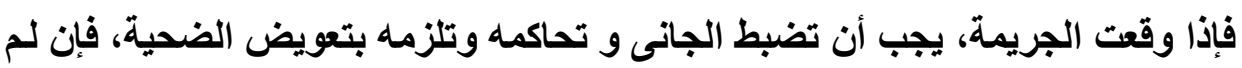

$$
\text { (1) نبيل محمود حسن، المرجع السابق، ص \& ^. }
$$

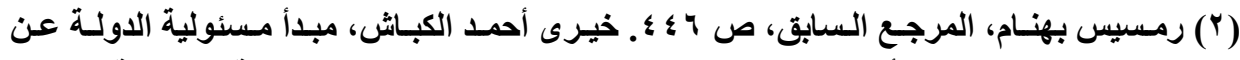

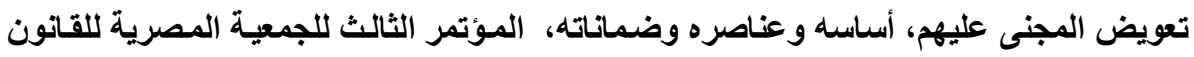
الجنائى بغوان حقوق المجنى عليه فى الإجراءات الجنائية، دار النهضية العربية، ـ99 19. 19 ص ص 
تتمكن من معرفة الجانى أو تبين أنهه معسر، لـ يبق أمامها إلا التزام أدبى واجتمـاعى بتعويض المضرور، من منطلق وظيفتها الاجتماعية فى مساعدة المضرورين('). وعلى ذلك، فالتزام الدولة بتعويض ضحية الجريمة هنا التزاما احتياطيا، بمعنى أن الدولـة ضـامنا احتياطيا، وبالتـالى تستطيع الحلـول محل المجنى عليهه قبل الجـانى المسئول عن الضرر. وإذا حصلت الضحية على تعويض عما أصابها من أضرار من جهة أخرى، فبان الدولة يمكنها المطالبة باسترداد كل أو بعض التعويض الأى دفعته له(). أما تحمل الدولة تبعة تعويض ضحايا الجرائم المرتكبة من رجال سلطتها العامـة بالتجاوز لحدود هذه السلطة، فهو يقوم قانونـا على فكرة مسئولية التابع عن أعمـال

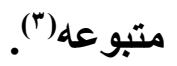
وبناء على الأسـاس الاجتمـاعى لمسئولية الدولة، يعتبر التعويض الذى تدفعه الدولـة منـــة أو مسساعدة اجتماعيـة منهـا، وليس حقـا للضحية، وبالتـالى، سبقتصر التعويض على من يحتـاج مساعدة الدولة، كمـا يمكن للاولـة أن تضع حدا أدنى وحدا أقصى للتعويض على حسب القدرة المالية للاولة)(؛)

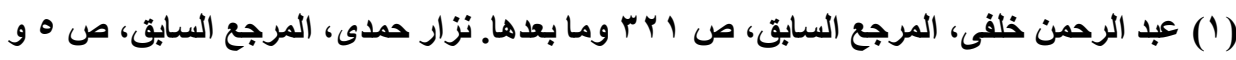

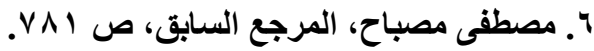

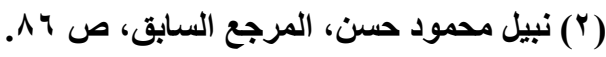

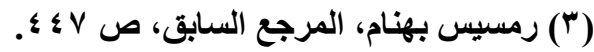

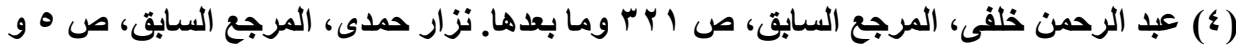

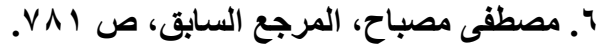

TV O مجلت البحوث القانونيت والإقتصاديت 
ونرى مع البعض(') أن أساس مسئولية الدولة عن تعويض الضحايا يرجع إلى

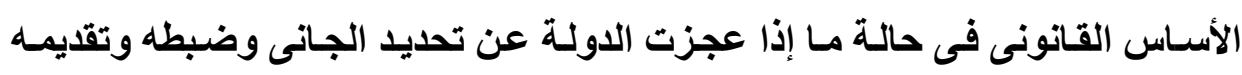

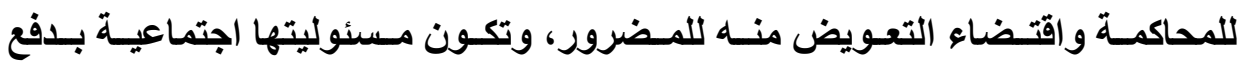
التعويض فى حالة ما إذا تمكنت من ضبطه وتقديمه للعدالة ولكن اتضح عجزه عن دفع التعويض نتيجة لإعساره. 


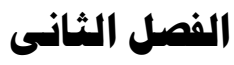 \\ صندوق الضمان كوسيلة لتعويض \\ ضحايا الاتجار بالبشر
}

\begin{abstract}
تمهيد وتقنيم
بعد أن انتهينا إلى تقرير مسئولية الدولة عن تعويض ضحايا الاتجار بالبشر، كان لابد من إنشاء نظام أو آلية لتعويض الضحية من جانب الدولة. فتم إنشاء صناديق تهدف إلى تعويض ضحايا الاتجار بالبشر عن الأضرار التى أصابتهم من جراء الاتجـار بهم واستغلالهم، فى حالة عجزهم عن الحصول على تعويض من الجـانى، سواء لعدم مقدرته المالية أو لعدم القبض عليه أو عدم تحديد هويته أو لعم إدانته. وبناء على ما تقدم، نرى تقسيم هذا الفصل إلى مبحثين، على النحو الآتى: المبحث الأول: القواعد المنظمة لعمل صندوق الضمان. المبحث الثانى: تقييم نظام التعويض من خلال صندوق الضمان.
\end{abstract}




\section{المبحث الأول}

\section{القواعد المنظمة لعمل صندوق الضمان}

نبين أولا المقصود بالـصندوق والهـف منـه، ثـم ثانيـا أنـواع التعويض الذَى يقدمه، ونتناول فى ثالثا تنظيم الصندوق، ورابعا نذكر مصادر تمويله، وذلك على النحو

\section{أولا: الاتصود بالصندوق والهدف هنه:}

قـ يـفع التعويض لـضحايا الاتجـار بالبشر، في بعض النظم القانونيـة، مـن صناديق تابعة للاولة، وسواء نشأت هذه الصناديق لتعويض ضحايا الجرائم الخطيرة بصفة عامة، أو لتعويض ضحايا الاتجار بالبشر بصفة خاصة('). ويُقصد به: صندوق ينشأ لتعويض ومساعدة ضحايا الاتجار بالبشر، وتكون لـه الثخصية الاعتبارية العامة، ويتولى تقديم المساعدات المالية لضحية الاتجـار بالبشر،

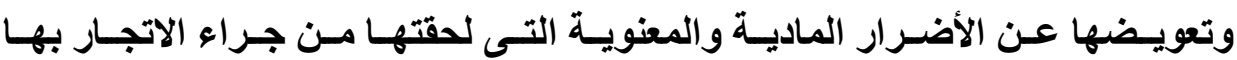
واستغلالها، فى حالة عجزها عن الحصول على تعويض من الجانى، سواء لعدم مقدرته المالية أو لعدم القبض عليه أو عدم تحديد هويته أو لعدم إدانته.

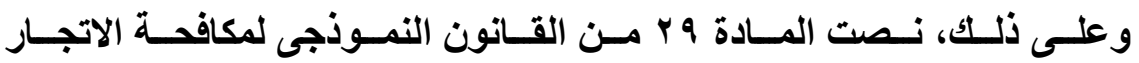
بالأشخاص، والمتعلقة بتعويض ضحايا الاتجار بالأشخاص، على أنه:

(1) Criminal Injuries Compensation Authority, A guide to the Criminal Injuries Compensation Scheme 2012, Crown, 2013, P. 1. Also, Frances Simmons, previous reference, P. 528.

TVA مجلة البحوث القانونيت والإقتصاديت 
" ا ـ دونما مساس بصلاحية المحكمة لتأمر الجانى بدفع تعويض إلى ضحية الاتجار

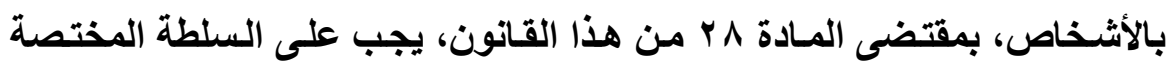

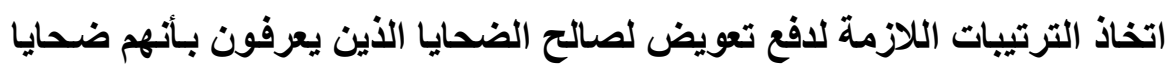

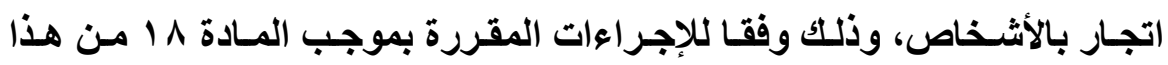
القانون. ويجب أن تحدد تلك الترتيبات جملة من الأمور، ومنها ما يلى: أ- الظروف التى يجوز أن يدفع فيها التعويض؛

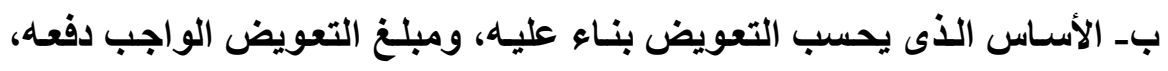

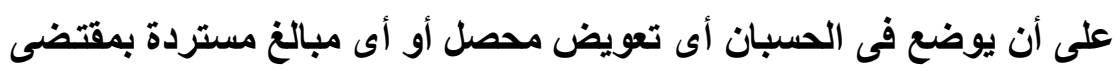

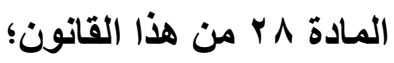
ج- الصندوق الذى تدفع منه المبالغ؛ لدـ إجراءات تقيم الطلبات لافع التعويضات؛ هـ إجراءات مراجعة واستئناف القرارات الصادرة بثأن المطالبات بالتعويض. r- يجب على السلطة المختصة ضمان إتاحة الإمكانية لضحايا الاتجار بالأشخاص لتقديم طلب التمساس لافع التعويض لهم بمقتضى هذه المـادة، حتى وإن لم يتم تحديد هوية الجانى أو القبض عليه أو إدانته.

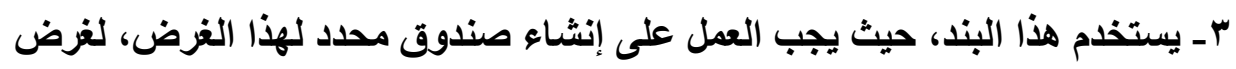

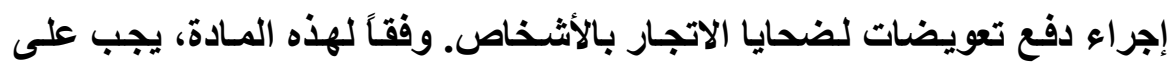
السلطة المختصة إنشـاء صـندوق لـصالح الضـايا، وكـللك تعيـين المسئولين الإداريين للصندوق. ويقبل المسئولون الإداريسون تلقى المبالغ التى تدفع إلى لى

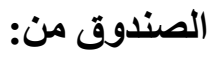


أ ـ الأموال المخصصة للصندوق وفقا للقانون المالى المعنى؛

بـ الأموال المصادرة، والعوائد المتأتية من بيع البضائع، أو الموجودات المالية

$$
\text { المصادرة، بمقتضى أحام القانون الوطنى؛ }
$$

جـ المدفوعات الطوعية أو المنح أو الهبات المقدمة إلى الصندوق؛

دـ الإيرادات أو الفوائد أو الأرباح المستمدة من استثمارات الصندوق؛

هـ أى مصدر آخر يسميه المسئولون الإداريون عن الصندوق.

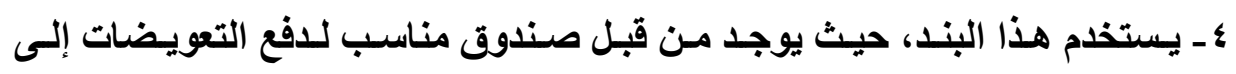

الضحايا. ويجب على السلطة المختصة ضمان أن يكون لاى المسئولين الإداريين عن الصندوق الصلاحية لدفع مبالغ التعويض لضحايا الاتجار بالأشخاص، وفقا

$$
\text { ل لهذه المادة. }
$$

ه - وضع الهجرة الخاص بالضحية أو إعادته إلى وطنه أو غياب آخر لله خارج الولاية القضائية المعنية، لا تعتبر أسبابا تمنع المحكمة من الأمر بدفع تعويض للضحية

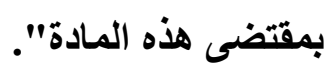

وقد جـاء فى التعليق على هذه المـادة أن: "إحدى الطرائق الكفيلة بتعويض

الضحايا عن الأضرار التي سببها الجانى، وذلك بمعزل عن القضية الجنائية، وسواء هوهاء أمكن التعرف على هويـة الجـانى أو الحكم عليهه أو معاقبته،، أم لا، إنمـا هى في إنشاء

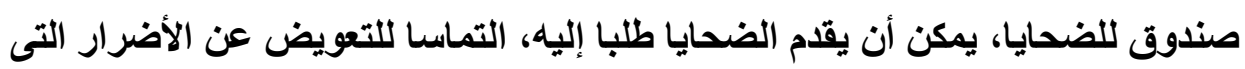

$$
\text { لحقت بهم. }
$$

وتتص الفقرتان r ا و با من إعلان المبادئ الأساسية لتوفير العدالـة لضحايا

$$
\text { الجريمة و إساءة استعمال السلطة على ما يلى: }
$$

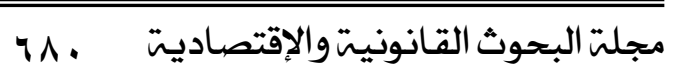


"Y ا ـ حيثمــا لا يكون مـن الممكن الحصول على تعويض كامـل مـن المجرم أو مـن مصادر أخرى، ينبغي للاول أن تسعى إلى تقديم تعويض مالى إلى:

أ ـ الضحايا الذين أصييوا بإصـابات جسدية بالغة، أو بـاعتلال الصحة البذنيـة أو

$$
\text { العقلية، نتيجة لجرائم خطيرة؛ }
$$

بـ أسـر الأشـخاص المتـوفين، أو الذين أصبحوا عـاجزين بـنيا أو عقليـا، نتيجة للإيذاء، وبخاصة، من كانوا يعتمدون فى إعالتهم على هؤلاء الأشخاص.

ب ا - ينبغى التشجيع على إنشاء وتعزيز وتوسيع الصناديق الوطنيـة المخصصة لتعويض الضحايا. ويمكن أيضا، عند الاقتضاء، أن تنشأ صناديق أخرى لهذا الغرض، بما فى ذلك، الحالات التى تكون فيها الدولة، التى تتنمى إليها الضحية،

$$
\text { عاجزة عن تعويضها عما أصابها من ضرر". }
$$

ويمكـن إنسشاء صـندوق للـضحايا يخـصص تحديــا لـصالح ضـحايا الاتجــار بالأشخاص، أو كما فى حالة عدد من البلدان، لصالح ضحايا الجرائم الخطيرة عموما'ا'. والخيار الثاني هو المفضل، لأن إدارة صندوق واحد فقط أسهل من إدارة عدة صناديق لأنـواع مختلفـة مـن الضحايا. ويمكن أن تقتصر الأهـاف المنشودة منـه على تقديم المساعدة والتعويض للضحايا، أو على توسيع نطاقه ليثمل التكاليف ذات الصلة بمنع

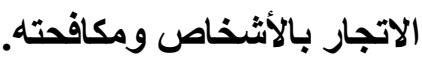
وينبغى إرساء أسس إدارة الصندوق وفقا للبنى التنظيمية القائمـة، وذلك على سبيل المثال، فى لوائح تنظيمية أو تشريعات جانبية.

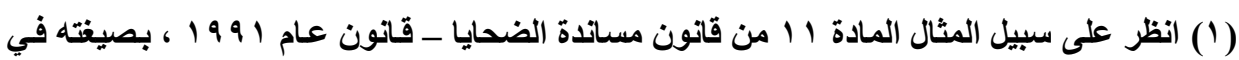

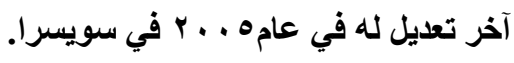

$$
\text { مجلت البحوث القانونيت والإقتصاديت 111 }
$$


ويجوز أن تشتنمل اللـوائح التنظيميـة على أحكام تفصيلية بشأن إدارة عمل

$$
\text { الصندوق، وعلى سبيل المثال، كما يلى: }
$$

"تستخدم أموال الصندوق وموجوداته المالية على النحو التـالى، (تدرج هنـا

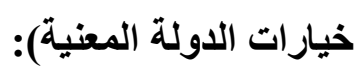

"أ ـ مـن أجل التعويض عن الأضرار الماديـة وغير الماديـة التى تلحق بضحايا

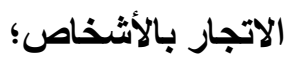

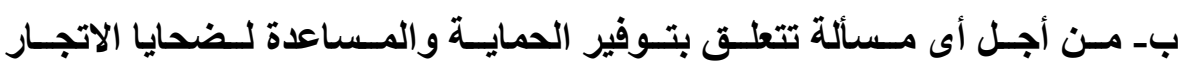

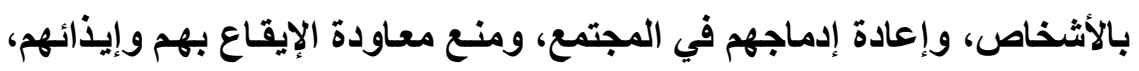

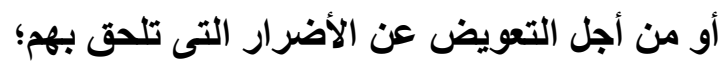
ج- بثأن توفير المساندة المادية الأساسية لضحايا الاتجار بالأثخاص؛ دـ من أجل توفير التعليم لضحايا الاتجار بالأثخاص، وكنلك التّريب المهنى لهه؛ هـ مـن أجل إنشاء مسأوى، وغير ذلكت مـن خدمات المسـاعدة للضحايا الاتجـار

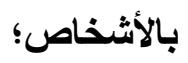
وـ من أجل توفير التـريب، وتنميـة القدرات للأشـخاص الذين لهم صلة بتوفير

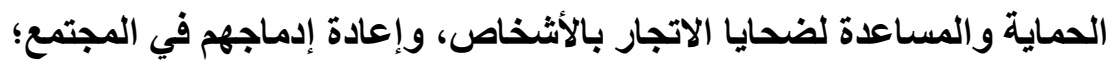
زـ من أجل أى عمل يتعلق بمشاركة الضحايا في الإجراءات الجنائية المتخذة بشأن

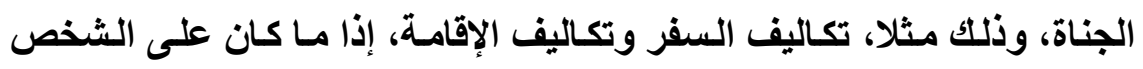
الضحية أن يمكث فى مكان آخر، غير مكان إقامته المعتاد، والتكاليف الطارئـة

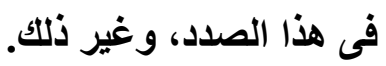


"يتولى إدارة شئون الصندوق مجلس أمناء يعين من قبل الوزير". "يتولى مجلس الأمناء تنظيم الإجراءات الخاصة بعمله فى لوائح تنظيمية، بمـا فى ذلك، إجـراءات النظر فـى طلبـات التمـاس المسـاعدة المقدمسة مـن ضـحايا الاتجـار بالأشـخاص والمواقةـة عليهـا؛ ويجب إقرار تلكـ الإجراعات الخاصـة بموجب مرسـوم حكومى" وقد جاء فى هذا التعليق، أحد الأمثلة على إدراج صندوق من هذا النوع فى

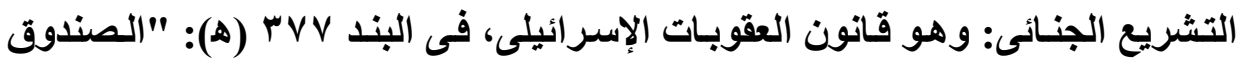

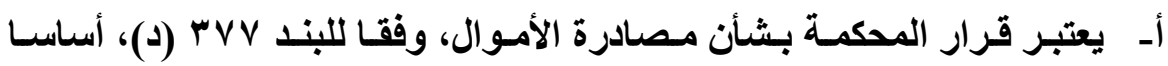
يستيتـ إليـه المسئول الإدارى العـام لـضبط الممتلكـات المـصادرة؛ وتحـول الممتلكات التى تمت مصادرتها، أو ما يقابلها من أموال، إلى المسئول الإدارى العام، الأي يودعها فى صندوق خـاص، تدار شئونه وفقا للوائح التنظيمية التى تصدر وفقا للبند الفرعى (د)، (في هذا البند - الصندوق). ب- تودع فى الصندوق أى غرامة تفرضها المحكمة بشأن جرم ما.

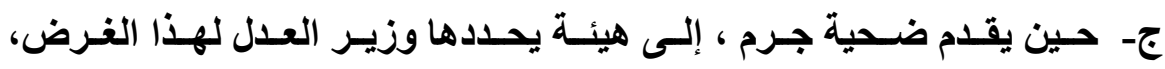
حكما صادرا بالحصول على تعويض، ويبين أنسه ليست لايسه إمكانية معقولنة لتحقيق الحكم الصادر، كليا أو جزئيا، وفقـا لأى قانون مطبق، يدفع لضحية الجرم من الصندوق، التعويض الوارد فى الصكم الصادر، والأى لم يتم سداده،

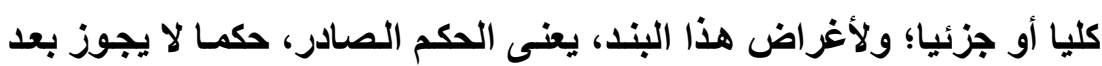


دـ يصدر وزير العدل، بموافقة لجنة الاستور والقانون والعدالة، التابعة للكنيست،

فى لائحسة تنظيميـة الطرائق التى تتبـع فـى إدارة شـئون الصندوق، وكيفيـة استخدام موجودات الصندوق المالية، وكيفية توزيعها لهذه الأغراض:

1 - إعادة تأهيل ضحايا الجرائم ومعالجتهم وحمايتهم؛ ولهذا الغرض، يخصص سنويا مبلغ لا يقل عن نصف قيمة موجودات الصندوق لعام واحد؛

ץ ـ دفع التعـويض المقرر فـى الحكـم الـصادر لـضحية الجـرم، وفقـا للأحكـام المنصوص عليها فى البند الفرعي (ج)؛

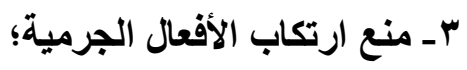

ـ ـ القيـام بوظـائف سـلطات إنفــاذ القـوانين، فـى إنفــاذ أحكــام هـذا القـانون،

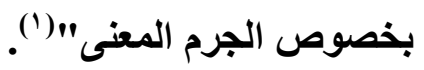

كمـا أنسشأت الأمـم المتحـدة صـندوقا لتقــيم المسساعدات الإنسسانية والقانونيـة والماليـة لضـحايا الاتجـار بالبشر، وبخاصـة النساء والأطفـال، وذلك مـن خـلال تقديم مسـاعدات مـن المنظمـات الحكوميـة المحليـة والدوليـة، والمنظمـات غيـر الحكوميـة. ويـار هـا الـصندوق وفقـا للنظـام المـالى والقواعد الماليـة للأمسم المتحدة، وبمعرفـة مجلس أمنــاء، يتكـون مسن خمسة أثـخاص، مسن ذوى الخبـرة فـى مجـال الاتجـار

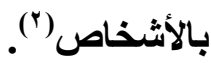

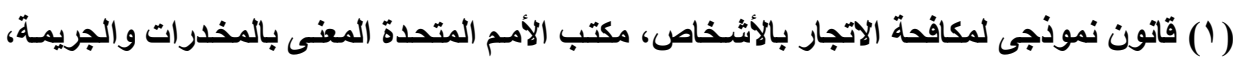

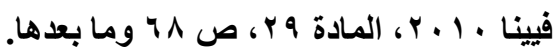

(2) Mohamed Mattar, Expert Consultation, Effective Remedies for Victims of Trafficking in Persons, Convened by the U.N. Special Rapporteur on trafficking in persons, especially women and children, previous reference, P. 23. 
وقد نصت المادة \ب من القـانون العربـى الاسترشـادى لمواجهة جرائم الاتجـار بالأشخاص، الصادر عن جامعة الدول العربية على أن: "ينشأ صندوق لمساعدة ضحايا جرائم الاتجار بالبشر، تكون له الشخصية الاعتباريـة العامـة، يتبع .....، ويتولى تقديم المسـاعدات المـاليـة للـــايا، ممـن لحقـت بهـم أضـرار نـاجمـة عـن أى مـن الجـرائم المنصوص عليها فى هذا القانون.

ويصدر بتنظيم هذا الصندوق، وتحديد اختصاصاته الأخرى، وموارده، ومصادر

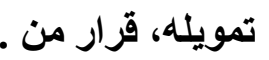

وتؤول حصيلة الغرامـات المقضى بها في الجرائم المنصوص عليها فى هذا القـانون، والأمسوال والأدوات ووسـائل النقـل التـى يحكـم بمـصادرتها، إلـى الـصندوق مباشرة، وللصندوق أن يقبل التبرعات والمنح والهبات من الجهات الحكومية وغير

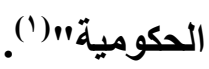

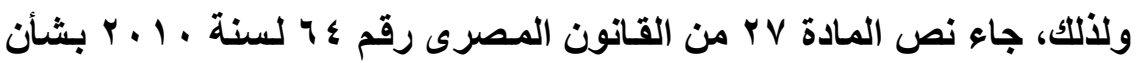

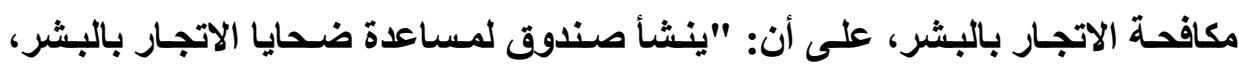
تكون لـه الشخصية الاعتباريـة العامسة، يتبع رئسيس مجلس الـوزراء، ويتولى تقديم المساعدات المالية للمجنى عليهه، ممن لحقت بهم أضرار ناجمة عن أى من الجرائم المنصوص عليها فى هذا القانون. ويصدر بتظيم هذا الصندوق، و تحديد اختصاصاته الأخرى، وموارده، ومصادر تمويله، قرار من رئيس الجمهورية. 
وتؤول حصيلة الغرامـات المقضي بها في الجرائم المنصوص عليها فى هذا

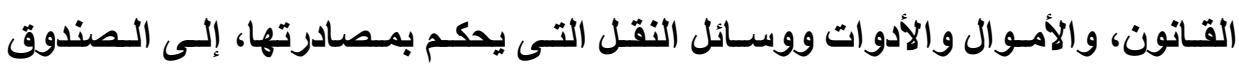

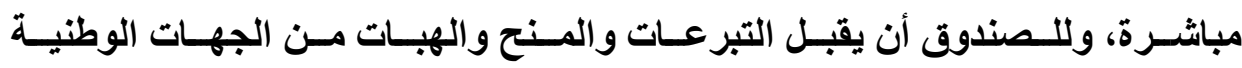

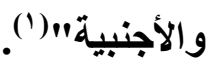

كما أخذت جورجيا بنظام التعويض من خلال صندوق الدولة، حيث نصت المسادة

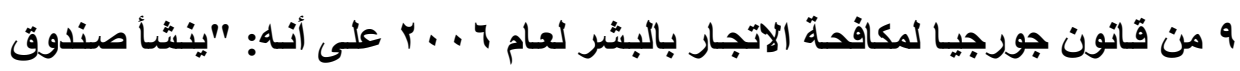

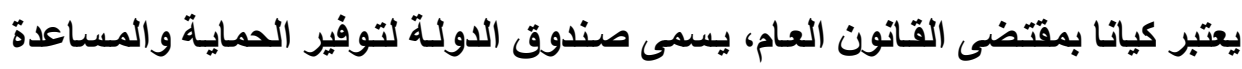

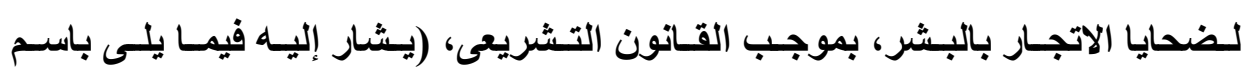

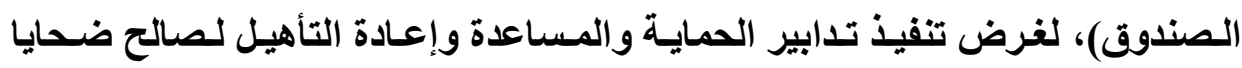

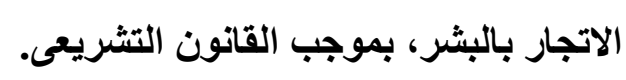

ا - تتولى وزارة العمل والصحة والحمايـة الاجتماعيـة فى جورجيـا السلطة على

$$
\text { الصندوق. }
$$

r- تخضع إدارة الصندوق لمديره، الذى يخضع فى تعيينه وتسريحه من منصبه

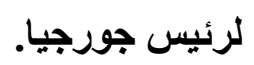

r- - ينشأ مجلس إثراف، ليتولى التنسيق بين أعمال الصندوق. ويتكون المجلس

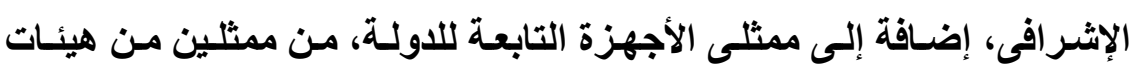
اعتبارية، ومنظمات دولية غير هادفة إلى الربح، عاملة فى الميادين ذات الصلة الصنة بالموضوع، ومن اختصاصيين علماء من ذوى الصلة بالموضوع أيضا. عـ تحدد بموجب القوانين التشريعية بنية الصندوق التنظيمية، وقواعد تيسير 
عمله. ويوافق رئيس جورجيا على النظام الداخلى للصندوق، بناء على توصية

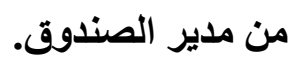

هـ الغرض مـن الصندوق، صـرف التعويضات لـصالح ضـحايا الاتجـار بالبشر،

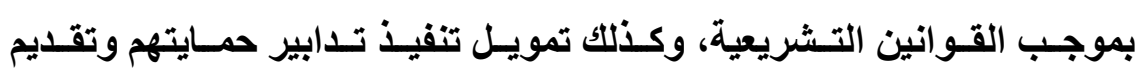
المساعدة إليهم وإعادة تأهيلهر.

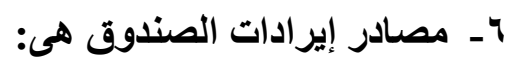

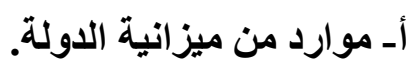

بـ موارد متلقاه من المنظمات الدولية المعنية. ج- مساهمات من هيئات اعتبارية أو أثخاص طبيعيين. دـ إيرادات أخرى مسموح بالحصول عليها بمقتضى تشريعات صـادرة فى

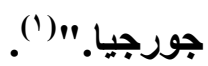

\section{ثانيا: أنواع التعويض الذى يقدهه الصندوق}

تستخدم أموال الصندوق وموجوداته المالية على النحو الآتى: 1ـ ـ من أجل التعويض عن الأضرار المادية وغير المادية التى تلحق بضحايا الاتجار

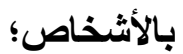

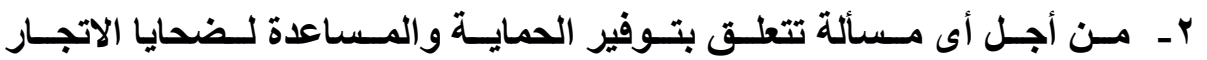
بالأثخاص، وإعادة إدماجهم في المجتمع، ومنع معاودة الإيقاع بهم وإيذائهم، أو من أجل التعويض عن الأضرار التى تلحق بهم؛ بهال

(1) قانون جورجيا لعام 7 ، . ب الخاص بمكافحة الاتجار بالبشر. I NV مجلة البحوث القانونيت والإقتصاديت 
r- - بشأن توفير المساندة المادية الأساسية لضحايا الاتجار بالأشخاص؛ ع - من أجل توفير التعليم لضحايا الاتجار بالأشخاص، وكذلك التدريب المهنى لهم؛ هـ - مسن أجـل إنـشاء مسأوى، وغيـر ذلـك مـن خـدمات المسـاعدة لـضحايا الاتجـار بالأشخاص؛ 7- من أجل توفير التـريب، وتنميـة القدرات للأشـخاص الذين لهم صـلة بتوفير الحماية والمساعدة لضحايا الاتجار بالأشخاص، وإعادة إدماجهم في المجتمع؛ V- من أجل أى عمل يتعلق بمشاركة الضحايا فى الإجراعات الجنائية المتخذة بشأن

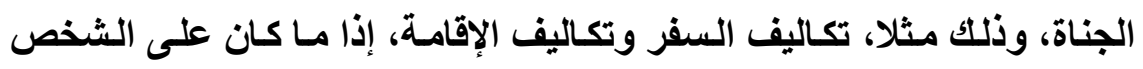
الضحية أن يمكث فى مكان آخر، غير مكان إقامته المعتـاد، والتكـاليف الطارئسة

فى هذا الصدد، وغير ذلك( (1).

1- التعويض عن الإصابات الجسدية البالغة، أو اعتلال الصحة البدنية أو العقلية. 9- تعويض أسر الأثخاص المتوفين، أو الذين أصبحوا عاجزين بـنيا أو عقليا،

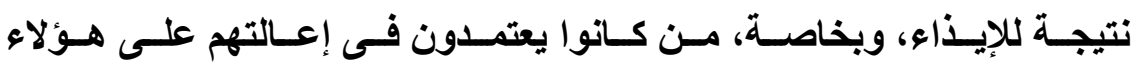

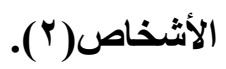
• 1 - إعادة تأهيل ضحايا الجرائم ومعالجتهم وحمايتهم.

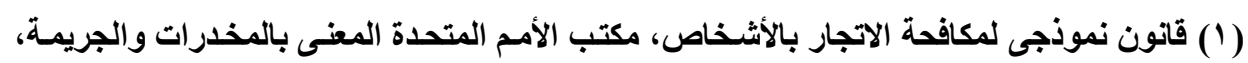

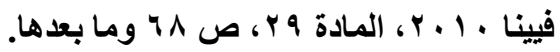

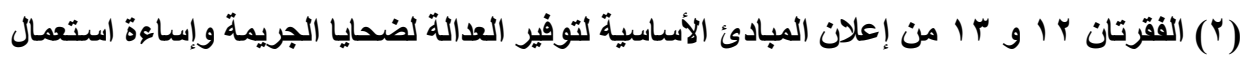
السلطة. مجلت البحوث القانونيت والإقتصاديت 


\section{ثالثا: تنظيم الصندوق}

ينبغى إرساء أسس إدارة الصندوق وفقا للبنى التظيمية القائمة، والتى تختلف

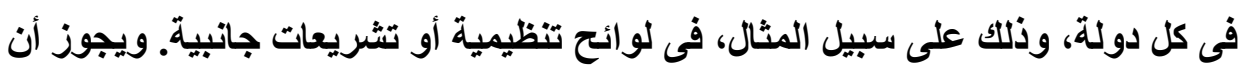
تشتمل اللوائح التظيمية على أحكام تفصيلية بشأن إدارة عمل الصندوق. فمثلا، قـ يتولى إدارة شئون الصندوق مجلس أمناء يعين من قبل الوزير، ويتولى مجلس الأمنـاء

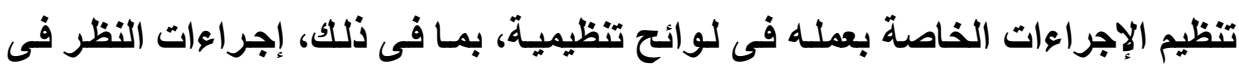

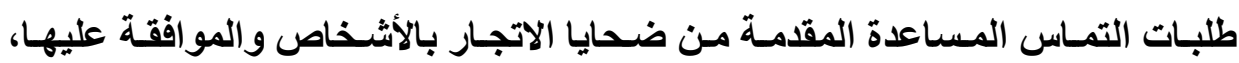
ويجب إقرار تلك الإجراءات الخاصة بموجب مرسوم حكومى '(

كمـا أنسشأت الأمسم المتحـدة صـندوقا لتقــيم المسـاعدات الإنسـانية والقانونيـة والماليـة لضحايا الاتجـار بالبشر. ويـار هذا الصندوق وفقـا للنظـام المـالى والقواعد المالية للأمم المتحدة، وبمعرفة مجلس أمنـاء، يتكون من خمسة أثـخاص، مـن ذوى الخبرة فى مجال الاتجار بالأشخاص(). وقد نصت المادة جس من القـانون العربس الاسترشـادى لمواجهة جرائم الاتجـار بالأشخاص، الصادر عن جامعة الدول العربية على أن: "ينشأ صندوق لمساعدة ضحايا جرائم الاتجار بالبشر، تكون له الثخصية الاعتباريـة العامـة، يتبع .....، ويتولى تقديم

(1) قانون نموذجى لمكافحة الاتجار بالأثخاص، مكتب الأمم المتحدة المعنى بالمخدرات والجريمـة،

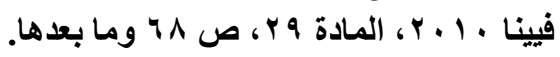

(2) Mohamed Mattar, Expert Consultation, Effective Remedies for Victims of Trafficking in Persons, Convened by the U.N. Special Rapporteur on trafficking in persons, especially women and children, previous reference, P. 23. 
المسـاعدات المـاليـة للـــايا، ممـن لحقـت بهـم أضـرار نـاجمـة عـن أى مـن الجـرائم المنصوص عليها فى هذا القانون.

ويصدر بتنظيم هذا الصندوق، وتحديد اختصاصاته الأخرى، وموارده، ومصادر

$$
\text { تمويله، قرار من ........" (1") }
$$

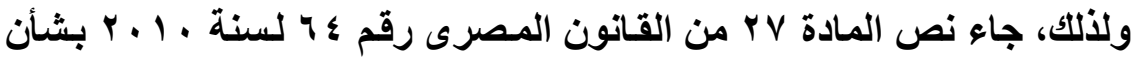
مكافحة الاتجـار بالبشر، على أن: "ينشأ صندوق لمساعدة ضـحايا الاتجـار بالبشر، تكون لـه الثخصية الاعتباريـة العامـة، يتبع رئسيس مجلس الـوزراء، ويتولى تقديم المساعدات المالية للمجني عليهم، ممن لدقت بهم أضرار ناجمـة عن أى من الجرائم المنصوص عليها فى هذا القانون. ويصدر بتظظيم هذا الصندوق، و تحديد اختصاصاته الأخرى، وموارده، ومصادر

$$
\text { تمويله، قرار من رئيس الجمهورية...."("). }
$$

كمـا أخذت جورجيـا بنظـام التعويض مـن خلال صندوق الدولـة، والذى يتمثل

$$
\text { تنظيمه فى الآتى: }
$$

اـ تتـولى وزارة العمل والصحة والحمايـة الاجتماعيـة فى جورجيـا السلطة على

$$
\text { الصندوق. }
$$

r ـ تخضع إدارة الصندوق لمديره، الذى يخضع فى تعيينه وتسريحه من منصبه لرئيس جورجيا.

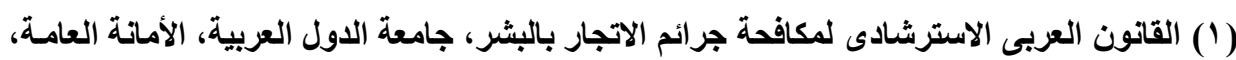

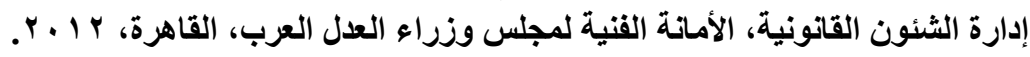

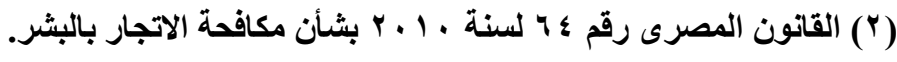

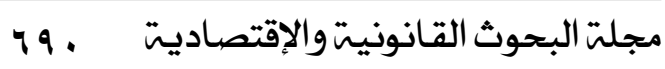


r- ينشأ مجلس إثراف، ليتولى التنسيق بين أعمال الصندوق. ويتكون المجلس الإشـرافى، إضـافة إلى ممثلى الأجهزة التابعة للاولـة، مـن ممثلين مـن هيئات اعتبارية، ومنظمات دولية غير هادفة إلى الربح، عاملة فى الميادين ذات الصلة بالموضوع، ومن اختصاصيين علماء من ذوى الصلة بالموضوع أيضا. ع ـ تحدد بموجب القوانين التشريعية بنيـة الصندوق التظظيمية، وقواعد تيسير عله. ويوافق رئيس جورجيا على النظام الداخلى للصندوق، بناء على توصية

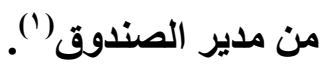
وهكذا يختلف تنظيم صندوق الدولـة لتعويض ضـحايا الاتجـار بالبشر وتقديم المساعدات لهم من دولة إلى أخرى، على النحو الذى تراه مناسبا للإشراف والرقابـة عليه، وضمان فاعليته فى وصول التعويض إلى الضحايا.

\section{رابعا: هصادر تمويل الصندوق}

تتعدد مصادر تمويـل صندوق الدولـة لتعويض ضـحايا الاتجـار بالبشر، والتى

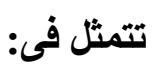
ا - الأموال المخصصة للصندوق وفقا للقانون المالى المعنى r- الأموال المصادرة، والعوائد المتأتية من بيع البضائع، أو الموجودات الماليـة المصادرة، بمقتضى أحام القانون الوطنى؛ r- المدفوعات الطوعية أو المنح أو الهبات المقدمة إلى الصندوق؛ ـ - الإيرادات أو الفوائد أو الأرباح المستمدة من استثمارات الصندوق؛ 
هـ أى مصدر آخر يسميه المسئولون الإداريون عن الصندوق(')؛ 7- تقديم مسـاعدات مـن المنظمـات الحكوميـة المحليـة والدوليـة، والمنظمـات غير

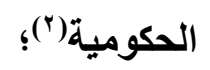

V- حصيلة الغرامات والأموال والأدوات ووسائل النقل التى يحكم بمصادرتها(").

ونظرا لأهمية الغرامات وعائدات الجريمة ومصادرة الممتلكات وتميز ها كمصدر

لتمويل صندوق الدولة لتعويض ضحايا الاتجار بالبشر، فسنعرض لها بالتفصيل على

$$
\text { النحو الآتى: - n }
$$

\section{الغرامات وعائدات الجريمة وهصادرة الممتلكات:}

كــلك، يمكـن اسـتخدام الغرامــات وعائسدات الجريمـة والممتلكــات المـصادرة

مـن المتجــرين أو المستخلين فـى تعـويض الـضـايا، أو لإعادتهــا إلــى أصـحابها

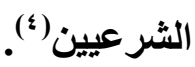

(1) المادة 9 Y من القانون النموذجى لمكافحة الاتجار بالأشخاص، والمتعلقة بتعويض ضحايا الاتجار

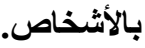

(2) Mohamed Mattar, Expert Consultation, Effective Remedies for Victims of Trafficking in Persons, Convened by the U.N. Special Rapporteur on trafficking in persons, especially women and children, previous reference, P. 23.

(ए) القانون العربى الاسترشادى لمكافحة جرائم الاتجار بالبشر، جامعة الدول العربية، الأمانة العامـة،

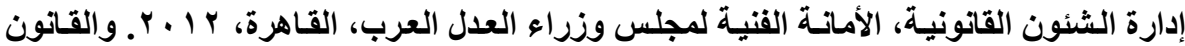

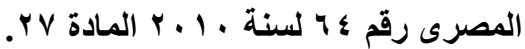

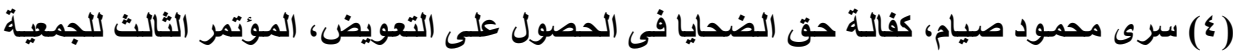

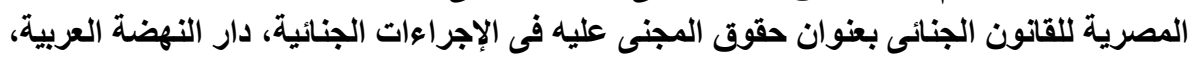

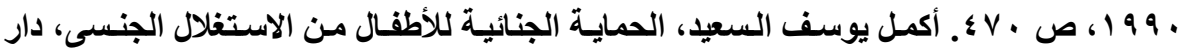

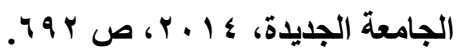

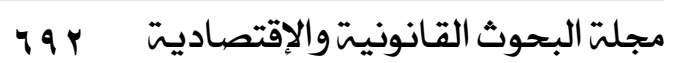


فمن المعروف أنه غالبا ما يكون هناك عائقا يحول دون حصول ضحايا الجريمـة على التعويض، يتمثل فى علم توفر الأموال اللازمة لدفع التعويض للاى الجـانى، حيث قد يلجأ هذا الأخير إلى نقل ممتلكاته خارج البلاد، أو إخفائها، لتجنب دفعها على سبيل التعويض. ولتجنب ذلك، يمكن للمحكة أن تأمر بتجميد هذه الممتلكات، و مصادرتها،

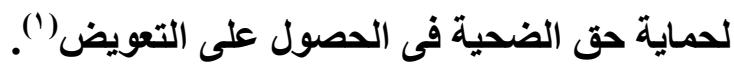
وجدير بالذكر، أنـه يجب أن يكون هنـاك ارتبـاط قـانونى صـريح بين مصادرة الممتلكات، والحكم بلدفع التعويضات، وإلا سيتم التأخر فى الحصول على التعويض، أو لون يحول دون الحصول عليه(`).

وعلى ذلك، تنص الفقرة r من المـادة ؛ ا من اتفاقية الأمـم المتحدة لمكافحة

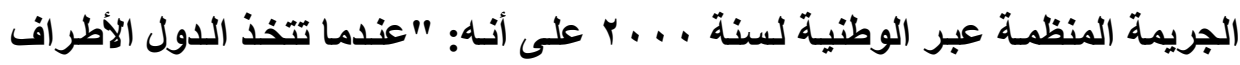
إجر اء ما، بناء على طلب دولة طرف أخرى، وفقـا للمـادة بـ أ من هذه الاتفاقية، تنظر

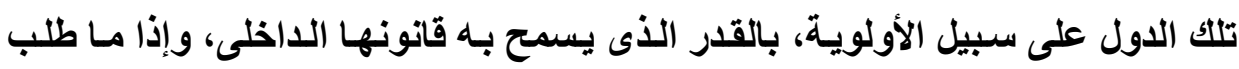

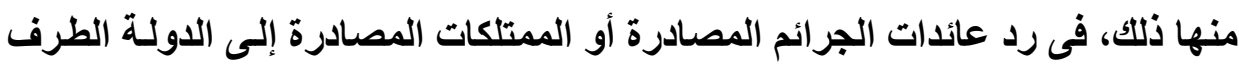

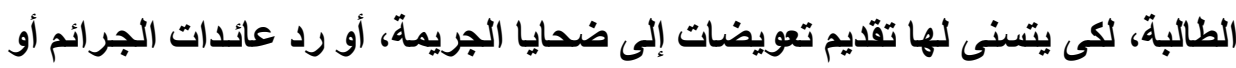

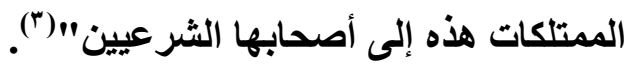

(1) Comp. act, European Action for compensation for trafficked persons, Guidance on representing trafficked persons in compensation claims, A practical tool for lawyers, counselling centres and service providers, toolkit on compensation for trafficked persons, No Date, P. 10.

(2) United Nations Office on Drugs and Crime, Global Initiative to Fight Human Trafficking, Anti-human trafficking manual for criminal justice practitioners, Module 13, Compensation for victims of trafficking in persons, previous reference, P. 9.

(3) UN Convention against Transnational Organized Crime (2000).

$$
\text { مجلتة البحوث القانونيت والإقتصاديت به }
$$


كما أكدت أيضا المبادئ الموصى بها والمبادئ التوجيهية التى تتعلق بحقوق

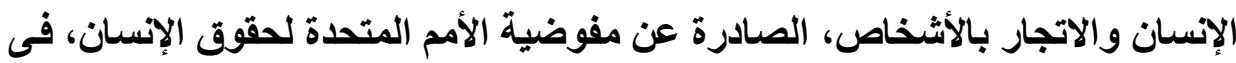
المبدأ التوجيهى رقم ؛ على ضرورة وضع حكم تشريعى، يسمح باستخدام الأدوات

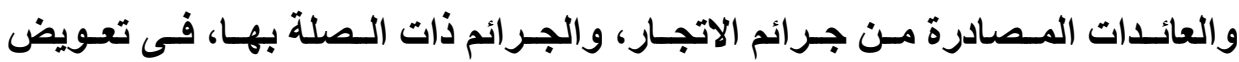
(الضحايا'(')

كمـا تنص بعض القوانين على أن تدفع التعويضات عن الأضرار إلى ضحايا الاتجار من الممتلكات المصادرة للمتجرين، وذلك كما فى المادة V؛ من قانون كمبوديا لقمع الاتجار بالبشر والاستغلال الجنسى لسنة 1 . . ب والتى تعطى الأفضلية للضحايا على الممتلكـات المصادرة بواسطة الدولـة، مـن أجل تعويضهم و جبر الأضـرار التى لهـ

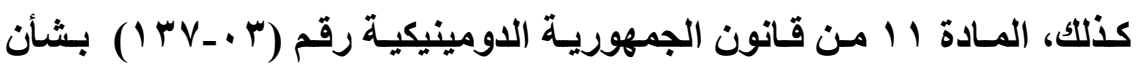

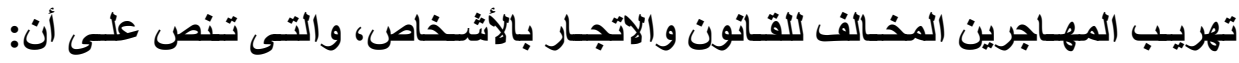

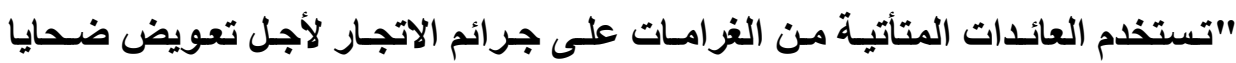

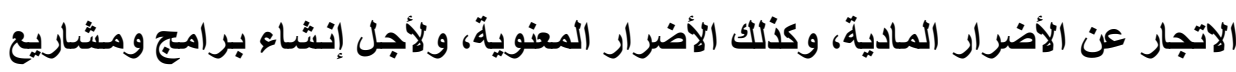
الحماية والمساعدة، التى ينص القانون على توفيرها لصالح ضحايا الاتجار"(").

(1) OHCHR, Recommended Principles and Guidelines on Human Rights and Human Trafficking, 2002.

(2) Chapter 7, Article 47, Cambodia, Law on Suppression of Human Trafficking and Sexual Exploitation, 2008. Mohamed Mattar, Expert Consultation, Effective Remedies for Victims of Trafficking in Persons, Convened by the U.N. Special Rapporteur on trafficking in persons, especially women and children, previous reference, P. 20.

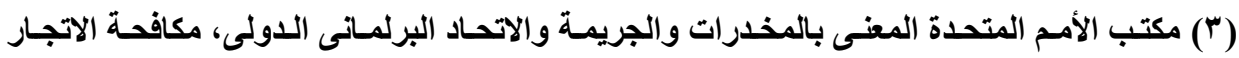
بالأشخاص، كتيب إرشادى للبرلمانيين، منشورات الأمم المتحدة، بدون تاريخ نشر ، ص 9 هـ

$$
\text { مجلة البحوث القانونيت والإقتصاديت } 9 \text { ـ } 9
$$


كـللك، يمكن أن تستخدم الممتلكـات المسصادرة فـى إنشاء أو المسساهمة فـى

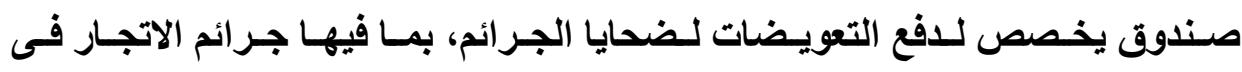

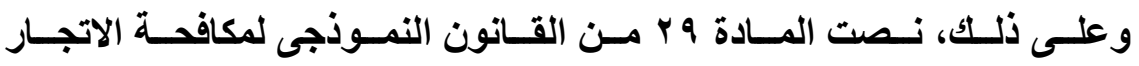

بالأشخاص، الصادر عن مكتب الأمم المتحدة المعنى بالمخدرات والجريمـة، على أن:"

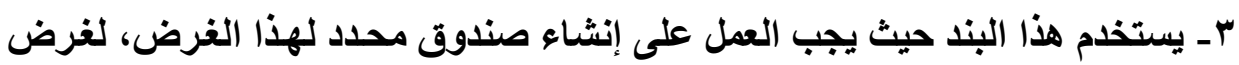

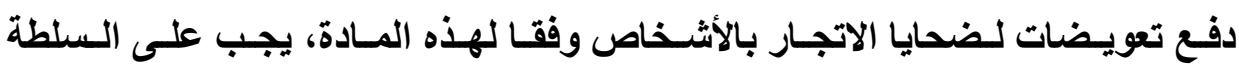
المختصة إنشاء صندوق لصالح الضحايا، وكذلك تعيين المسئولين الإداريين للصندوق. ويقبل المسئولون الإداريون تلقى المبالغ التى تدفع إلى الصندوق من: (ب) الأموال

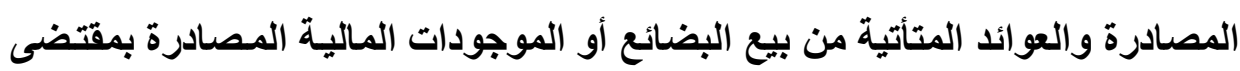

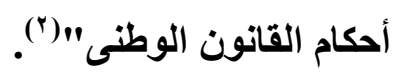

كما نصت المسادة وب من القانون العربس الاسترشـادى لمكافحة جرائم الاتجـار

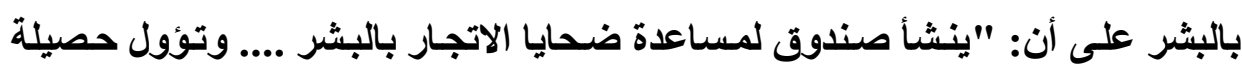
الغرامات المقضى بها فى الجرائم المنصوص عليها فى هذا القانون، والأموال والأدوات ووسائل النقل التى يحكم بمصادرتها إلى الصندوق مباشرة..."(").

(1) United Nations Office on Drugs and Crime, Global Initiative to Fight Human Trafficking, Anti-human trafficking manual for criminal justice practitioners, Module 13, Compensation for victims of trafficking in persons, previous reference, P. 9.

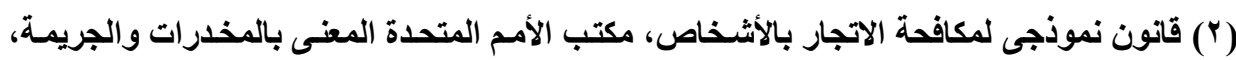

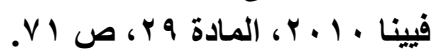

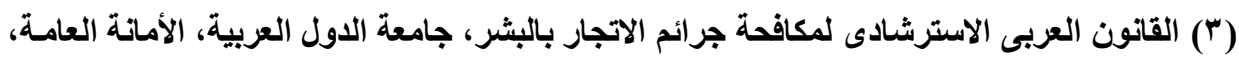

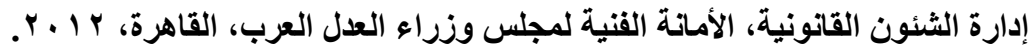




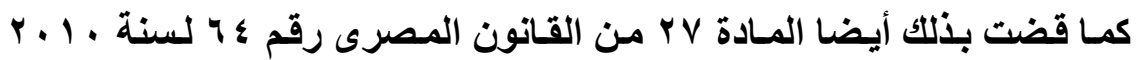
بثأن مكافحة الاتجار بالبشر.

وتطبيقا لما سبق، نذكر قضية ماريا التى كاتت تذهب كل يوم، بعد انتهاء الدوام فى المدرسـة، لبيع الخبز فى الشارع، لكى تكسب بعض النقود، وتضيفها إلى دخل فئل الأسرة المحدود، وكانت ماريا التى تبلغ من العمر خمسة عشر عامـا تتجـاذب الحديث مع امر أة تسمى صوفيا تبلغ من العمر خمسة وثلاثون عاما، تسكن معها فى ذات التهن القرية

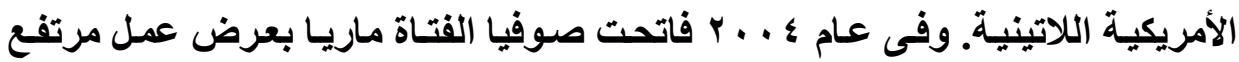

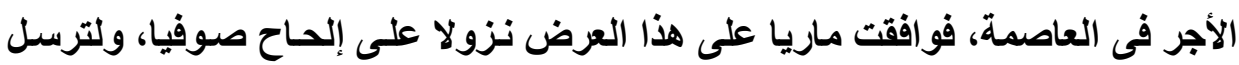
بعض المال إلى والديها لتساعدهما على الخروج من الفقر، ودون أن تبلغهمـا بالسفر.

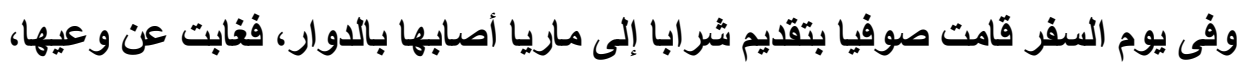

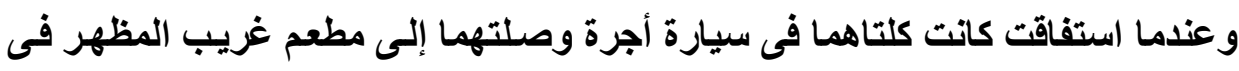

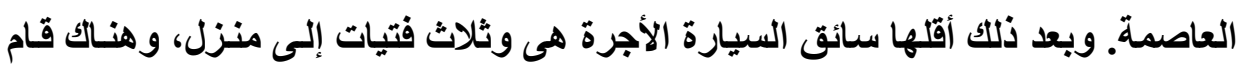

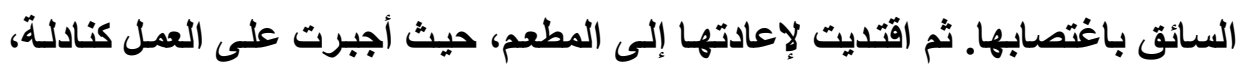

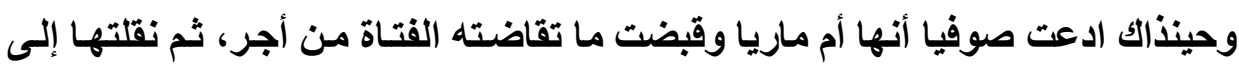

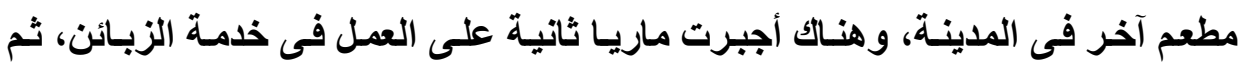

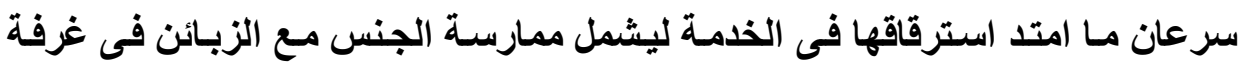
خلفية، ثم استمر الأمر هكذا حتى عملت فى مرقص، ورآهـا عمها هنـاك فأخبر والديها

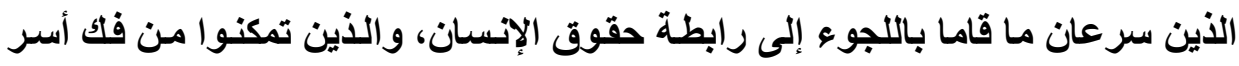

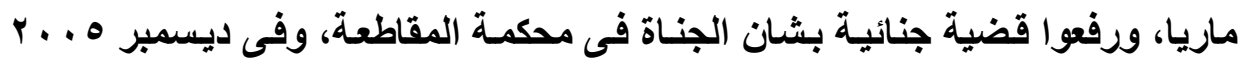

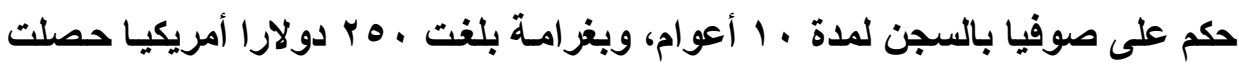

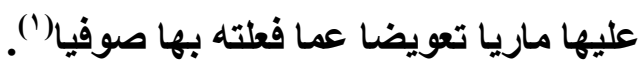




\section{المبحث الثاني \\ تقييم نظام التعويض هن خلال صندوق الضمان}

نرى مع البعض، أنه وإن كان الحصول على التعويض من خلال صندوق الدولة

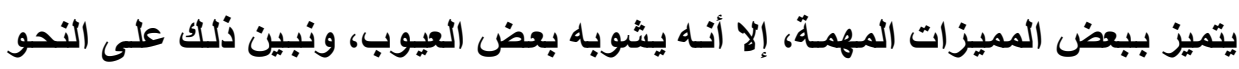
الآتى:

أولا: هميرات الجووء إلى صندوق الضهان

يتميز التعويض من خلال صندوق الدولة بأنه يمثل ضمانا لتعويض الضحية، فلا

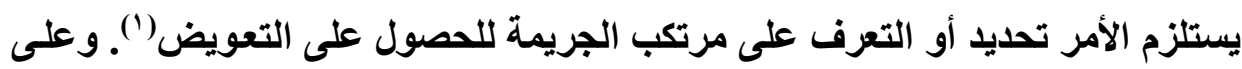

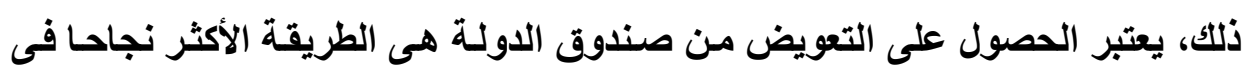
الحصول على التعويض للضحية)(")

إذن، يقوم صندوق الدولة بدور تكميلى أو بلدى فى تعويض ضحية الاتجار،

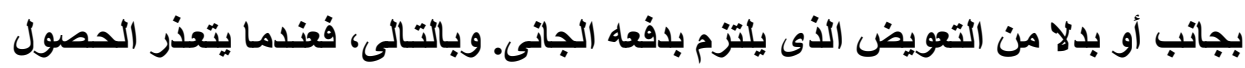

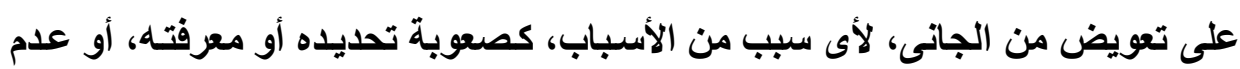

(1) United Nations Office on Drugs and Crime, Global Initiative to Fight Human Trafficking, Anti-human trafficking manual for criminal justice practitioners, Module 13, Compensation for victims of trafficking in persons, previous reference, P. 4.

(2) Elaine Pearson, previous reference, P. 81.

I9V مجلت البحوث القانونيتوالإقتصاديت 
قدرته على دفع التعويض، فيمكن اللجوء إلى صندوق الدولة، لتعويض الضحية عن

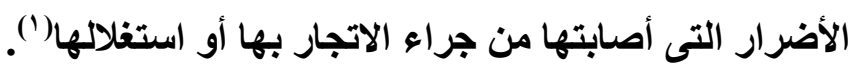
ثانيا: عيوب الججوء إلى صندوق الضمان ولكن يعيب على آلية التعويض من خلال صندوق الدولة أنـه غالبـا مـا يكون التعويض أقل بكثير من الأضرار التى لحقت بالضحية. كما أن هناك الكثير من القيود أو

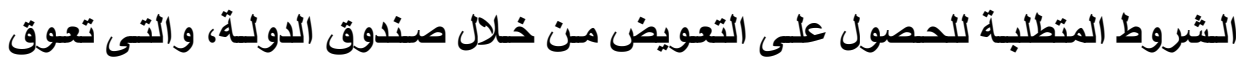

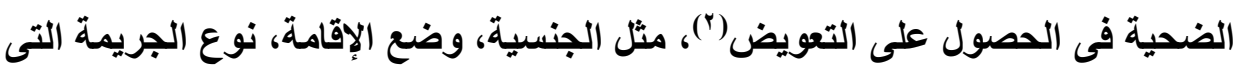

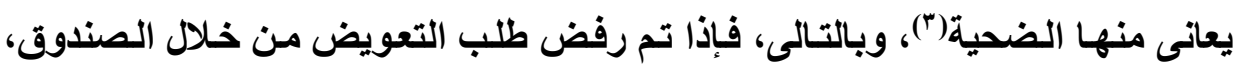
فسيؤدى ذلك إلى تفاقم الضرر النفسى الذى أصاب الضحية) (4)

ونرى أنه على الرغم من هذه العيوب، إلا أنها لا تقلل من مدى أهية اللجوء

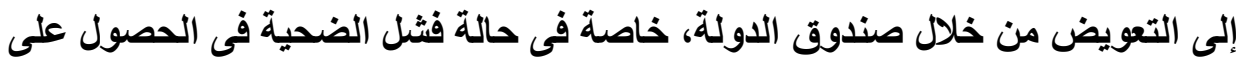

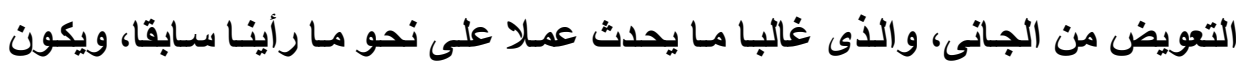
الملجأ الوحيد لضحية الاتجار بالبشر فى هذه الحالة هو صندوق الدولة، الذى يضمن له

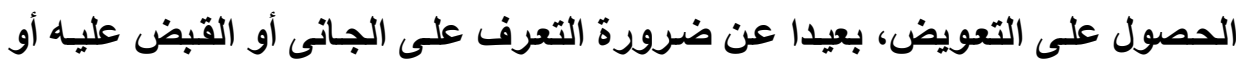

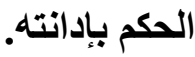

$$
\text { (1) (1) نصر اللاين بوسماحة، المرجع السابق، ص ro }
$$

(2) Lisanne de Weerd, previous reference, P. 25, 26.

(3) Joy Ezeilo, previous reference, P. 6.

(4) Comp. act, European Action for compensation for trafficked persons, Guidance on representing trafficked persons in compensation claims, A practical tool for lawyers, counselling centres and service providers, toolkit on compensation for trafficked persons, No Date, P. 8.

$$
\text { مجلتة البحوث القانونيت والإقتصاديت ه }
$$




\section{الخاتهة}

توصلنا من خلال هذا البحث إلى أن جريمة الاتجار بالبشر هى جريمة محلية

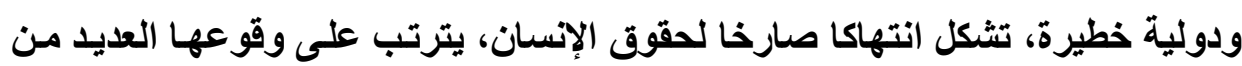
الأضرار المادية والبذنية والنفسية، التى يجب أن تعوض عنها الضحية، وذلكت لمـا

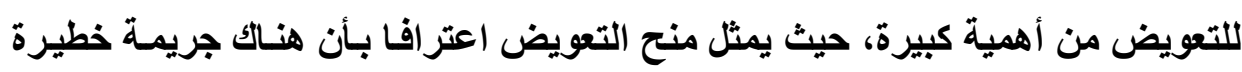

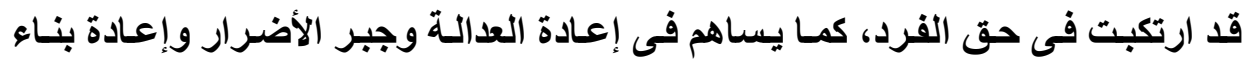

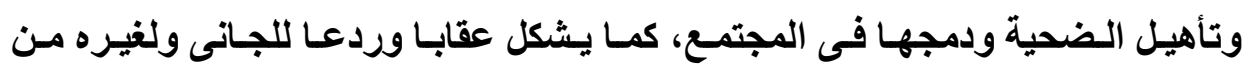
ارتكاب نفس الجريمة مرة أخرى.

كما توصلنا من البحث إلى أنه وإن كان الجانى هو المسئول الأول والأساسى

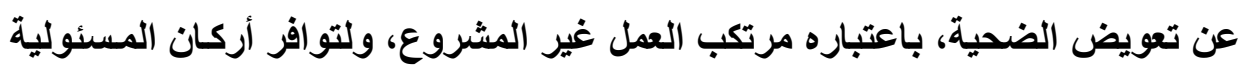

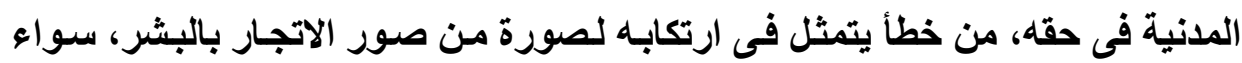

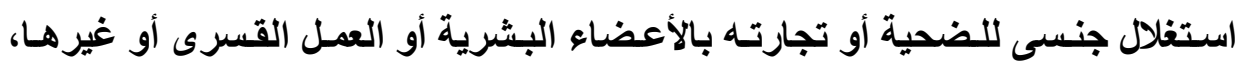

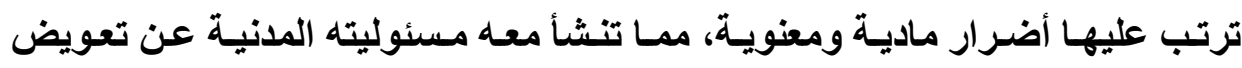

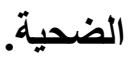

إلا أننا وجدنا صعوبة فى إمكانية حصول الضحية على التعويض من الجانى، إما

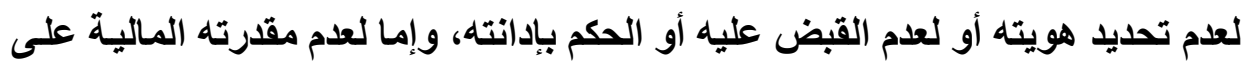

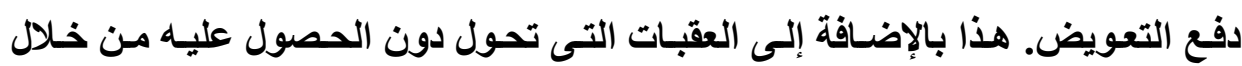

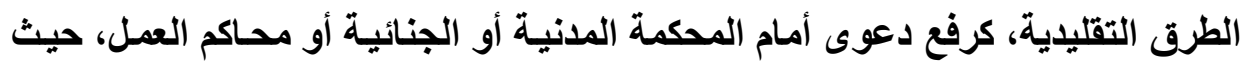

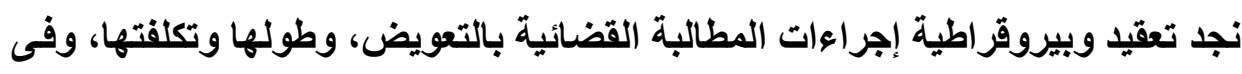

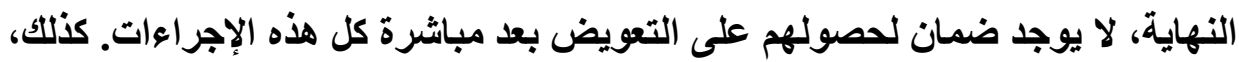

مجلت البحوث القانونيتو الإقتصاديت 999 
نقص القدرات والمعرفة والخبرة من جاتب السلطة القضائية والمحامين فى التمساس التعويض للأشخاص المتاجر بهم، مع عدم وجود المساعدة القانونيـة، خاصـة، لمن لـ تكن لايه دراية كافية بالإجراعات القانونية الواجبة الاتباع للحصول على التعويض. مما جعلنا نبحث عن مدى مسئولية الدولة عن تعويض ضحايا الاتجار بالبشر، ووجدنا أنها تنعقد مسئوليتها عن التعويض، والتى ترجع إلى أساس قانونى، يتمثل فى واجبها بحمايـة المواطنين، والذى فى حال عجزهـا عن القيـام بهذا الواجب، تلتزم إلى بتعويض الضحايا عن الأضرار التى أصسابتهم من الجريمـة. أمسا فحى حالـة توفيرهـا هذه الحمايـة، بـالقبض على مرتكب الجريمـة ومعاقبتهـ، ولكن ثبـت عدم مقدرتـه الماليـة لتعويض الضحية، ففى هذه الحالـة تتعقد مسئولية الدولـة عن التعويض على أسـاس التضامن أو التكافل الاجتماعى.

ويموجب هذه المسئولية، التى أقرتها الاتفاقيات الدولية والقوانين الوطنيـة، أنثأت العديا من الدول صناديق لتعويض ضحايا الاتجـار بالبشر، تكون بمثابة ضمان للضحية فى الحصول على التعويض، بعيدا عن معرفة الجانى أو القبض عليه أو إدانته أو مدى مقدرته المالية عن تعويض الضحية. وباستقراء النصوص القانونية التى وردت فى الاتفاقيات الدولية والتشريعات

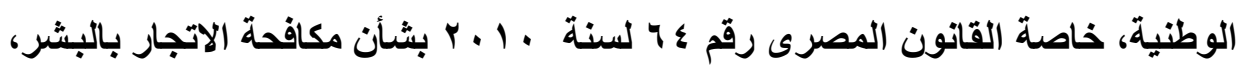
نجد أن بروتوكول منع وقمع ومعاقبة الاتجار بالأشخاص، وبخاصـة النساء والأطفـال، المكـل لاتفاقيـة الأمــم المتحـدة لمكافــة الجريمـة المنظمــة عبـر الوطنيـة، والقـانون

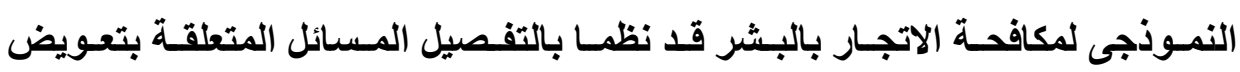
الضحايا، كذكرهم لأنواع التعويض، وأنواع الأضرار التى يجب التعويض عنها، وتقرير 
مسئولية الدولة عن التعويض، وتنظيم صندوق الاولة لتعويض الضحايا، مـع ذكرهم لمصادر تمويله وغيرها من الأمور المهمة. فى حين نجد أن الأمور المتعلقة بـالتعويض لم تنل نفس الاهتمـام فى القـانون

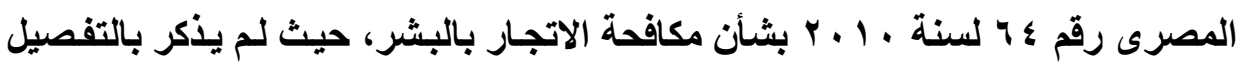
لأنواع التعويض، وأنواع الأضرار التى يجب التعويض عنها، ولم يقرر فرض تعويض عقابى أو ردعى يهذف إلى ردع مرتكب هذه الجريمـة الخطيرة. وعلى الرغم من هذا

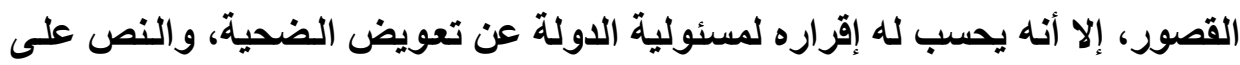
إنشاء صندوق للتعويض، وتنظيمه له وذكر مصادر تمويله المتعددة. 
بعد انتهائنا من البحث، وتوصلنا إلى ما سبق من نتائج، نرى ضرورة التوصية بالآتى:

أولا: يجب أن تضمن الدول تدريب سلطاتها المختصة، مثل الشرطة ومسئولى الهجرة

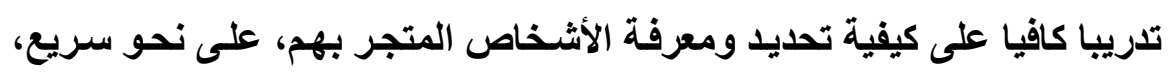

$$
\text { وبثكل دقيق. }
$$

ثانيا: مـن أجل تمكين الأثـخاص المتجر بهم مـن الحصول على التعويض بطريقة

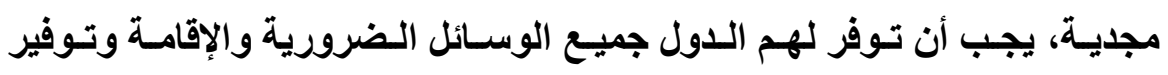

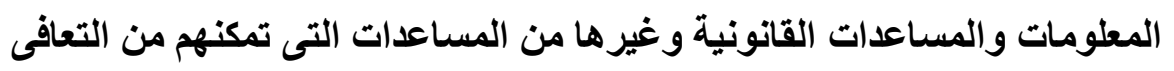

$$
\text { التام، والتظلب على عقبات الحصول على التعويض. }
$$

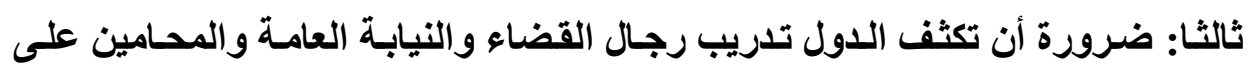

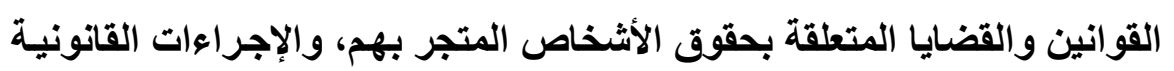

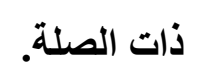

رابعا: يجب على الدول أن تدرب السلطات المكلفة بإنفاذ القانون على تحديد ومعرفة وتعقب وتجميد ومصادرة الأموال المتعلقة بجريمة الاتجار بالبشر.

خامسا: النص صراحة فى التشريع على أن تستخدم الأموال المصادرة فى تعويض الأثخاص المتجر بهم.

سادسا: ينبغى على الدول التى تسمح بتعويض ضحايا الاتجار من صندوق الدولة أن

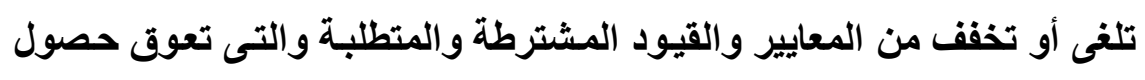

$$
\text { الضحايا على التعويض. تلفي من المعاير }
$$

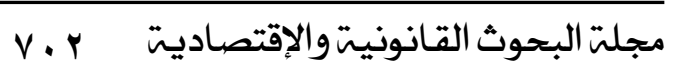


سـابعا: يجب أن تـوفر الـدول إقامـة مؤقتة غير مشروطة للضحايا، حتى يـتم القيـام بالإجراعات القانونية اللازمة للحصول على حقهم فى التعويض.

ثامنا: حث الجمعيـات الأهلية على مسـاعدة الضحايا الذين يعـانون من أوضـاع معقدة نتيجة الاتجار بهر.

تاسـعا: دراسـة إمكانيـة تقديم مسـاعدة ماديـة لأصـحاب الأعمـال، لتـوفير فرص عمـل للضحايا، بهدف إعادة دمجهم مجددا فى المجتمع.

عاشرا: إنشاء شرطة متخصصة بملاحقة جرائم الاتجار بالبشر، بالإضافة إلى استحداث وحدات لحقوق الإنسان بـأجهزة الشرطة لحمايـة حقوق الضحايا، ومساعدتهم وتبصير هم بتلك الحقوق.

حادى عشر: أن تتعاون الدول فيما بينها، تيسيرا لتعقب الجنـاة الهاربين من دولة إلى أخرى، والكشف عن أمسوالهم بمكسان ضسبطه، حتى يـتم استيفاء التعويض المستحق منهم.

ثانى عشر: يجب على الأشخاص المكلفين بتنفيذ القانون أن يعلم ضحية الاتجار بالبشر

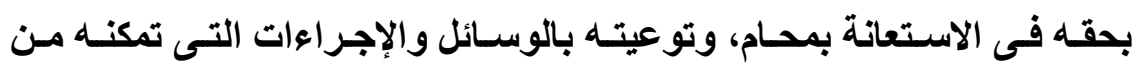
الحصول على التعويض.

ثالـث عشر: ضـرورة تـوفير الـدول للتمويـل الـلازم للمسـاعدة الاجتماعيـة والقانونيـة لضحايا الاتجار بالبشر. 


\section{قاعُمة المراجع}

\section{أولاً: المراجع باللغة العربية:}

- أحمد عبد اللطيف الفقى، الدولة وحقوق ضحايا الجريمة، تطبيق على ضحايا جرائم

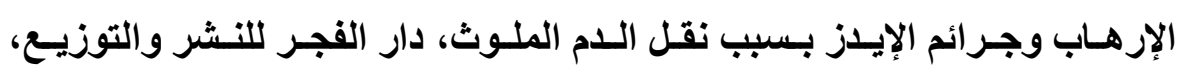

$$
r \cdot r
$$

- أشرف الدعدع، مرتكزات الوقاية من جرائم الاتجار بالبشر بدولة الإمسارات العربية المتحدة، فى إطار المبادرة العالميـة لمكافحة الاتجـار بالبشر بالتعـاون مـع برنـامج

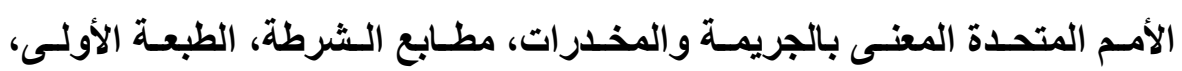

$r \cdot 1 r$

- أكرم فاضل، أسـاس المسئولية المدنية عن الإصـابات الجسـدية وتحديـ التعويض

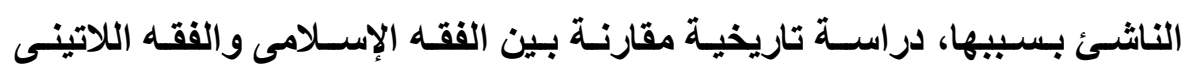

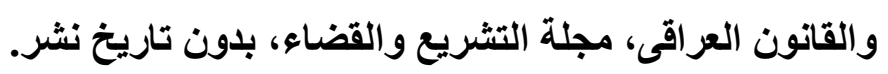
- أكمل يوسف السعيد، الحماية الجنائية للأطفال من الاستغلال الجنسى، دار الجامعة

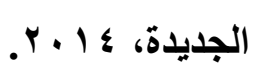

- - أمير فرج، الجريمـة المنظمـة وعلاقتها بالاتجـار بالبشر وتهريب المهاجرين غير

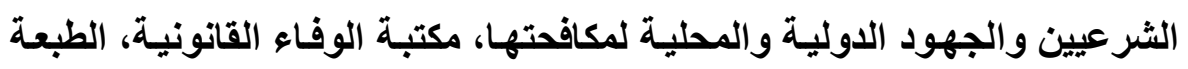

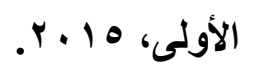

- أميرة محمــ بكر، الاتجـار بالبشر وبخاصـة الأطفـال، مـن وجهـة النظر العلميـة النفسية والاجتماعية والقانونية، دار النهضة العربية، 11 ـ ب؟.

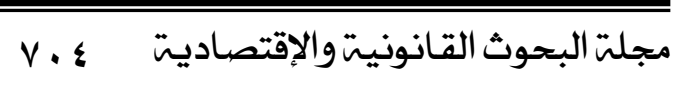




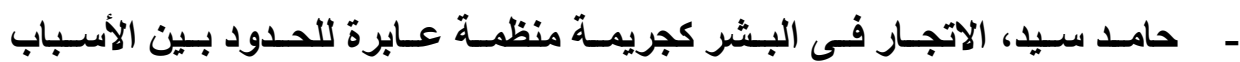
والتداعيات والرؤى الإستراتيجية، المركز القومى للإصدارات القانونيـة، الطبعة الطبة

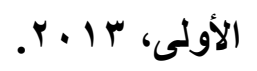

- خيرى أحمد الكباش، مبدأ مسئولية الدولة عن تعويض المجنى عليهم، أساسـه

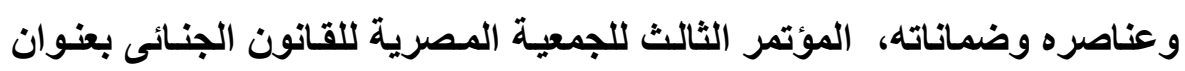
حقوق المجنى عليه فى الإجراءات الجنائية، دار النهضة العربية، . 199. - رائد كاظم، التعويض فى المسئولية التقصيرية، مجلة الكوفة، العدد ^، بدون تاريخ نشر. - رمسيس بهنام، مثكلة تعويض المجنى عليه فى الجريمة، المؤتمر الثالث للجمعية

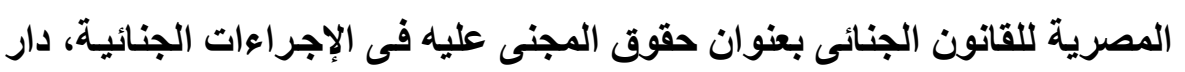

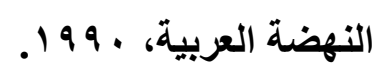
- رمضان عبد الله، تعويض المضرور عن جرائم الأفراد مـن قبل الدولـة وكيفيـة

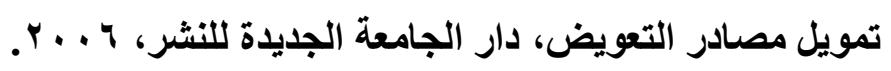
- سالم إبراهيم، جرائم الاتجار بالبشر واستراتيجيات مكافحتها على الصعيدين الدولى

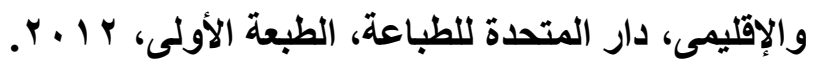
- سرى محمود صيام، كفالة حق الضحايا فى الحصول على التعويض، المؤتمر

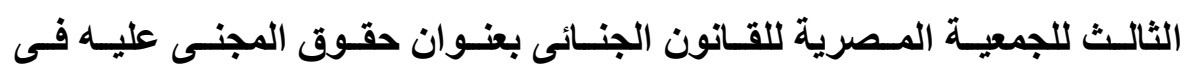
الإجراءات الجنائية، دار النهضة العربية، . 99 19.

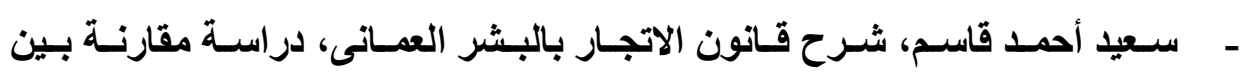

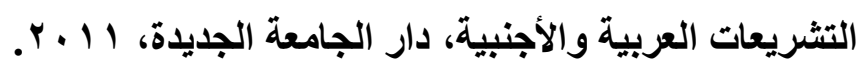


- سيد عبد الوهاب، النظرية العامة لالتزام الدولة بتعويض المضرور من الجريمة،

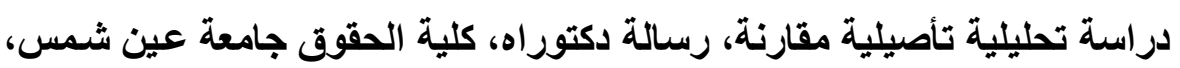

$$
\text { r..r }
$$

- طارق عفيفى، النظام القانونى لحماية حقوق ضحايا الاتجار بالبشر، دراسة مقارنة

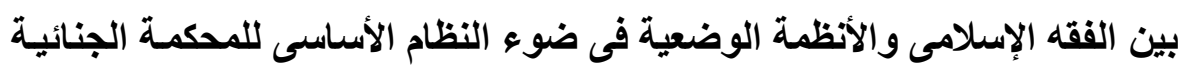
الدولية والاتفاقيات والقوانين ذات الصلة، المركز القومى للإصدارات القانونية،

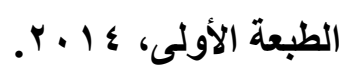

- عبد الرحمن خلفى، مدى مسئولية الدولة عن تعويض ضحايا الجريمة (الأسساس

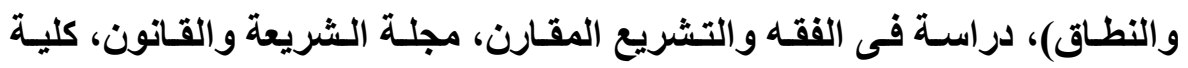

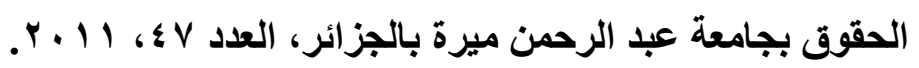
- محسن العبودى، أسساس مسئولية الدولة عن تعويض المجنى عليه فى القوانين

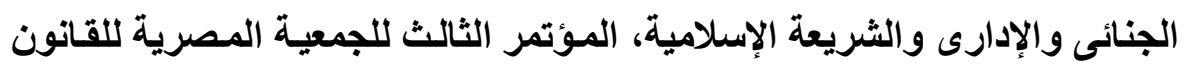

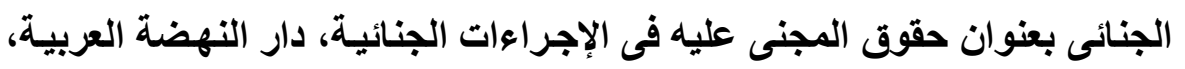

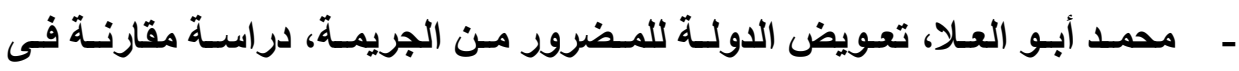

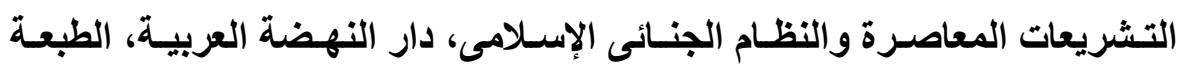

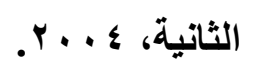

- محمد الشنناوى، إستراتيجية مكافـة جرائم الاتجـار فى البشر، المركز القومى

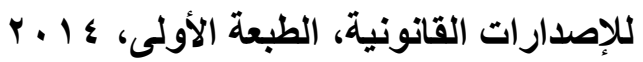
- محمـ صبحى نجم، دعوى التعويض أمسام المحكمـة الجنائيسة، المـؤتمر الثالت

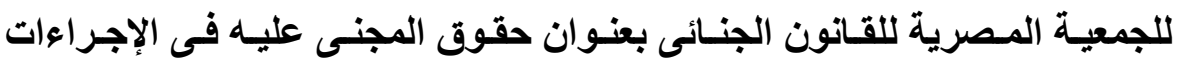

$$
\text { مجلت البحوث القانونيت والإقتصاديت }
$$




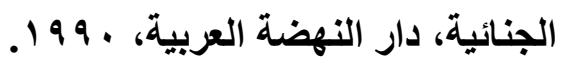

- محمد عبد اللطيف، تعويض المجنى عليه، دراسـة مقارنـة فى القـانون الوضعى

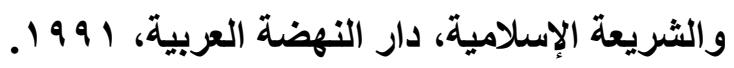
- محمد مطر، تشريعات حقوق الإنسان فى العالم العربـ، قضية الاتجـار بالبشر،

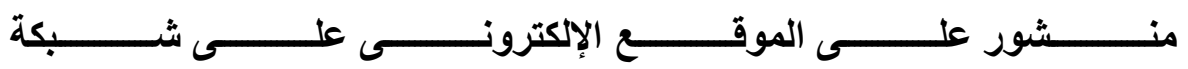
http://www.protectionproject.org:الإنترنت - محمد نور الدين، جريمـة بيع الأطفال والاتجـار بهم، دراسـة فى قانون العقوبـات المصرى والإمـاراتى وقوانين مكافحة الاتجار بالبشر والاتفاقيات والبروتوكولات

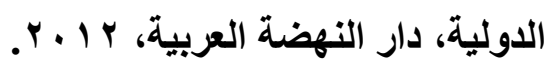

- محمد يحيى مطر، مكافـة الاتجـار بالأشـخاص وفقـا لمبـادئ الشريعة الإسـلامية، مكتب الأمم المتحدة المعنى بالمخدرات والجريمة، بدون تاريخ نشر. - مصطفى مصباح، وضع ضـحايا الإجرام فى النظام الجنـائى، دراسـة نقديـة للنظام الجنـائى فى ضـوء معطيـات علـم الضحية، رسـالة دكتور اه، جامعة الإسـكندرية،

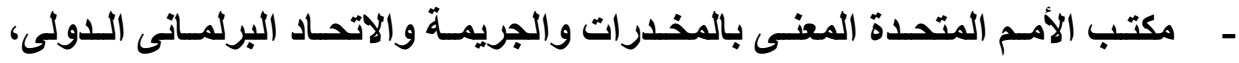
مكافحة الاتجار بالأشخاص، كتيب إرشـادى للبرلمـانيين، منشورات الأمـ المتحدة، بدون تاريخ نشر. - مدوح خليل، العنف ضـ النساء والأطفال، دراسـة فى القانون الجنـائى والقانون الدولى الإنسانى مع بيان موقف التشريع الإماراتى، دار التهضة العربية، I 1 ـ †. - بيل محمود حسن، الحماية الجنائية لضحايا الجريمة فى القانون الدولى الإنسانى، V.V مجلت البحوث القانونيتوالإقتصاديت 


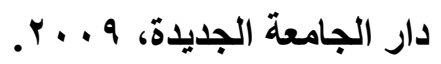

- - نزار حمدى، قراعة فى مبدأ التزام الدولـة بتعويض المتضرر عن جرائم الأفراد،

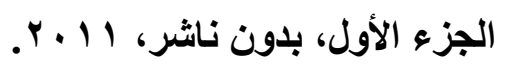

- نصر الدين بوسـماحة، حقوق ضحايا الجرائم الدولية على ضوء أحكام القـانون

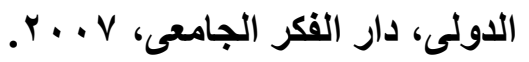

- نصير صبار، التعويض العينى، دراسة مقارنة، رسـالة ماجستير، جامعة النهرين،

$$
. r \cdot 1
$$

- وائل أحمد علام، الحماية الدولية لضحايا الجريمة، دار النهضة العربية، ؛ . . ب.

\section{ثانياً: المراجع بالاغة الأجنبية:}

- Alison Siskin and Liana Sun Wyler, Trafficking in Persons: U.S. Policy and Issues for Congress, Congressional Research Service, 2013.

- Alline Pedra Jorge-Birol, Empowering Victims of Human Trafficking: the Role of Support, Assistance and Protection Policies, HUMSEC Journal, Issue 2, No date.

- Anne T. Gallagher, The right to an effective remedy for victims of trafficking in persons: A Survey of International Law and Policy, Paper submitted for the expert consultation convened by the UN Special Rapporteur on Trafficking in Persons, especially women and children, Ms. Joy Ngozi

$$
\text { V. مجلم البحوث القانونيت والإقتصاديت }
$$


Ezeilo on: "The right to an effective remedy trafficked persons", Bratislava, Slovakia, 2010.

- April Rieger, MISSING THE MARK: WHY THE TRAFFICKING VICTIMS PROTECTION ACT FAILS TO PROTECT SEX TRAFFICKING VICTIMS IN THE UNITED STATES, Harvard Journal of Law \& Gender, Vol. 30, No date.

- Casey Rubenstein, Aftercare services for international sex trafficking survivors: informing US service and program development in an emerging practice area, Macy and Johns, 2011.

- Comp.act, European Action for compensation for trafficked persons, Guidance on representing trafficked persons in compensation claims, A practical tool for lawyers, counselling centres and service providers, toolkit on compensation for trafficked persons, No Date.

- Comp. act, European Action for compensation for trafficked persons, Findings and results of the European Action for compensation for trafficked persons, Toolkit on compensation for trafficked persons, 2012. 
- Criminal Injuries Compensation Authority, A guide to the Criminal Injuries Compensation Scheme 2012, Crown, 2013.

- Elaine Pearson, Human traffic, Human rights: Redefining victim protection, Anti- Slavery international organization, 2002.

- Frances Simmons, Making possibilities realities: Compensation for trafficked people, Sydney Law Review, Vol. 34:511, No date.

- Heather, Nicole, Amy, and Lisa, Study of HHS programs serving human trafficking victims, US department of health and human services, Final Report, December 2009.

- Jayashri Srikantlah, Perfect victims and real survivors: The iconic victim in domestic human trafficking law, Poston University Law Review, Vol. 87: 157, 2007.

- Jean Bruggeman \& Elizabeth Keyes, Meeting the Legal Needs of Human Trafficking Victims, An Introduction for Domestic Violence Attorneys \& Advocates, the American Bar Association, 2009.

- Joy Ezeilo, Report of the Special Rapporteur on trafficking in persons, especially women and children, United Nations, General assembly, 2011. 
- Kathleen Kim, Civil litigation on behalf of victims of human trafficking, The Legal Aid Foundation of Los Angeles, 2005.

- Lisanne de Weerd, Compensation for trafficked persons from state funds: Are compensation funds appropriate for trafficked persons? A critical examination of four state compensation funds in Europe, Master thesis, Amsterdam, 2011.

- Marco Gramegna and the EFUS team, Trafficking in Human Beings, International knowledge and local practices in connection with the "Guidance on local safety audits: A compendium of international practice", European Forum for Urban Safety (EFUS), 2007.

- Margaret Malloch, Tara Warden and Niall Hamilton, Care and Support for Adult Victims of Trafficking in Human Beings, Scottish Centre for Crime and Justice Research, 2012.

- Mohamed Mattar, Expert Consultation, Effective Remedies for Victims of Trafficking in Persons, Convened by the U.N. Special Rapporteur on trafficking in persons, especially women and children, Ms. Joy Ngozi Ezeilo, Bratislava, Slovakia, November 22-23, 2010. 
- Mohamed Mattar, Incorporating the Five Basic Elements of a Model Anti trafficking in Persons Legislation in Domestic Laws: From the United Nations Protocol to the European Convention, Tulane J. of INT'L \& COMP. LAW, Vol. 14:1, 2006.

- Mohamed Mattar, Trafficking in Persons: An Annotated Legal Bibliography, Law Library Journal, Vol. 96:4, 2004.

- NGO Committee to stop trafficking in persons, Recommendations on draft principles on the right to an effective remedy, 2012.

- Petra Follmar-Otto and Heike Rabe, Human trafficking in Germany, Strengthening Victim's Human Rights, German Institute for Human Rights, 2009.

- Theodore R. Sangalis, Elusive empowerment: Compensating the sex trafficked persons under the trafficking victims protection act, Fordham Law Review, Vol. 80, 2011.

- Tonny Moses and Radoslaw Lukasz, Guidelines for assisting victims of human trafficking in the East Africa Region, International organization for migration, 2011.

- United Nations Office on Drugs and Crime, Global Initiative to Fight Human Trafficking, Anti-human trafficking manual for criminal justice practitioners, Module 13, Compensation for victims of trafficking in persons, 2009. 